Водные биологические ресурсы

Динамика обилия массовых промысловых рыб дальневосточных морей и прилегающих районов открытой
части Тихого океана и влияющие на неё факторы

\author{
А.В. Датскийㄱ, В.В. Кулик², С.А. Датская \\ ${ }^{1}$ Всероссийский научно-исследовательский институт рыбного хозяйства и океанографии (ФГБНУ «ВНИРО»), Окружной проезд, 19, Москва, 105187 \\ 2 Тихоокеанский филиал ФГБНУ «ВНИРО» («ТИНРО»), пер. Шевченко, 4, Владивосток, 690091 \\ ${ }^{3}$ Московский государственный университет им. М.В. Ломоносова (ФГБОУ ВО «МГУ им. М.В. Ломоносова»), Ленинские горы, д.1, Москва, ГСП-1, 119991 \\ E-mail: adatsky@vniro.ru
}

Цель работы: нахождение закономерностей в формировании обилия массовых промысловых рыб дальневосточных морей и прилегающих районов открытой части Тихого океана, выявление абиотических, биотических и антропогенных факторов, воздействующих на численность рыб.

Используемые методы: для решения поставленной цели с 1937 по 2020 гг. проанализированы данные по биомассе, вылову и урожайности поколений 38 группировок морских рыб. В рамках обнаружения исходных факторов, оказывающих потенциальное влияние на биомассу гидробионтов, привлечены многолетние данные изменчивости природной среды. Для определения силы связи между факторами среды и обилием рыб впервые предложено использовать максимальный информационный коэффициент (МИК), расчёты которого произведены с применением языка программирования R и пакета Minerva.

Новизна: элементами новизны являются выявленные связи обилия рыб с определенными факторами среды через использование МИК, которые могут быть использованы для целей прогнозирования. Результаты исследования показали, что наибольшие значения обилия гидробионтов сформированы преимущественно поколениями высокой численности с периодичностью 6-13 лет (3-7 лет - у тихоокеанских лососей). По причине регионального воздействия абиотических и прочих факторов в динамике отдельных единиц запасов рыб в пределах видов выявлена отличная друг от друга цикличность. Среди 15 факторов среды, тесно связанных с обилием рыб, определяющими были температура воды в различных горизонтах (от поверхности до дна), ледовитость, цветение фитопланктона и биомасса различных фракций и видов зоопланктона. В то же время влияние рыболовства на численность исследуемых рыб на современном этапе незначительно.

Практическая значимость: примененный в настоящей работе метод прогнозирования уловов посредством учёта взаимодействия абиотических и прочих факторов среды и обнаруженных закономерностей в периодичности формирования обилия морских рыб позволит повысить эффективность использования их сырьевой базы.

Ключевые слова: морские рыбы, дальневосточные моря и прилегающие акватории открытой части Тихого океана, факторы среды, биомасса, вылов, урожайные поколения, максимальный информационный коэффициент, периодичность, прогнозирование.

\title{
The dynamics of the abundance of commercial fish in the Far Eastern seas and adjacent areas of the open part of the Pacific Ocean and factors influencing it \\ Andrey V. Datsky', Vladimir V. Kulik², Sofia A. Datskaya ${ }^{3}$ \\ ${ }^{1}$ Russian Federal Research Institute of Fisheries and Oceanography («VNIRO»), 19, Okruzhnoy proezd, Moscow, 105187, Russia \\ 2 Pacific branch of VNIRO («TINRO»), 4, per. Shevchenko, Vladivostok, 690091, Russia \\ ${ }^{3}$ Lomonosov Moscow State University («MSU»), 1, Leninskie Gory, Moscow, 119991, Russia
}

Purpose of the work: finding patterns in the formation of the abundance of large-scale commercial fish in the Far Eastern seas and adjacent areas of the open part of the Pacific Ocean, identifying abiotic, biotic and anthropogenic factors affecting the number of fish.

Methods used: to solve the set goal from 1937 to 2020. analyzed data on biomass, catch and productivity of generations of 38 groups of marine fish. Within the framework of the discovery of the initial factors that have a potential effect on the biomass of aquatic organisms, long-term data on the variability of the natural environment were used. To determine the strength of the relationship between environmental factors and the abundance of fish, it was for the first time proposed to use the maximum information coefficient (MIC), the calculations of which were made using the R programming language and the Minerva package.

Novelty: the elements of novelty are the identified relationships between the abundance of fish and certain environmental factors through the use of MICs, which can be used for forecasting purposes. The results of the study showed that the highest values of the abundance of aquatic organisms were formed mainly by generations of high abundance with a frequency of $6-13$ years (3-7 years for Pacific salmon). Due to the regional impact of abiotic and other factors in the dynamics of individual units of fish stocks within species, a different cyclicality was revealed. Among 15 environmental factors closely related to the abundance of fish, the 
determining factors were the water temperature in various horizons (from the surface to the bottom), ice cover, phytoplankton bloom, and the biomass of various fractions and species of zooplankton. At the same time, the influence of fishing on the number of studied fish at the present stage is insignificant.

Practical significance: the method for predicting catches used in this work by taking into account the interaction of abiotic and other environmental factors and the discovered patterns in the frequency of formation of the abundance of marine fish will increase the efficiency of using their raw material base.

Keywords: marine fish, the Far Eastern seas and adjacent water areas of the open part of the Pacific Ocean, environmental factors, biomass, catch, productive generations, maximum information coefficient, periodicity, forecasting.

\section{ВВЕДЕНИЕ}

Развитие промышленного рыболовства во многом зависит от имеющейся сырьевой базы морских рыб, промысловые запасы отдельных видов и популяций которых находятся в постоянной, зачастую разнонаправленной, динамике. В этой связи, достоверное прогнозирование уловов рыб на ближайшую и долгосрочную перспективу представляется важнейшей задачей, в ходе которой затрагиваются такие первостепенные вопросы как поддержание популяций в равновесном состоянии и их рациональное использование. В то же время успешное решение этой задачи затруднено отсутствием проверенных и долговременных материалов по биологии, численности и добыче отдельных единиц запаса, многофакторным влиянием природной среды и биоты на обилие рыб. Также важнейшими условиями решения вышеуказанной проблемы, помимо наличия исходных данных, являются профессиональные знания и умение определять численность гидробионтов с учётом её лимитирующих факторов.

Исходные данные для научной обработки начали поступать с начала 20-го века с формированием масштабного промысла трески Gadus morhua Linnaeus 1758, G. macrocephalus Tilesius, 1810 и сельди Clupea harengus Linnaeus 1758, C. pallasii Valenciennes, 1847 Северного и Дальневосточного регионов, тихоокеанских лососей р. Oncorhynchus, анчоусов сем. Engraulidae, сардины Sardinops melanostictus (Temminck et Schlegel, 1846), ставриды Trachurus japonicus (Temminck \& Schlegel, 1844) и скумбрии Scomber japonicus (Houttuyn, 1782) в северо-западной части Тихого океана. С 1950-х гг. стали появляться данные с промысла минтая Theragra chalcogramma Pallas, 1814, камбаловых рыб сем. Pleuronectidae, мойвы Mallotus villosus catervarius (Müller, 1776) и корюшек сем. Osmeridae. С развитием добывающих судов и орудий лова собиралась информация о среде обитания морских рыб, предпринимались попытки объяснить динамику их численности фоновыми условиями и антропогенным воздействием. Особенным вниманием пользовались идеи установления определённой цикличности в рыбопродуктивности объектов промысла и оправдываемости прогнозов их вылова. Подобные исследования заложили базовые принципы для понимания причин изменения численности морских рыб, отмечающие комплексное влияние на них множества факторов. Такие взаимосвязанные процессы в гидросфере, атмосфере и биосфере явились основой работ Г.К. Ижевского [1961; 1964], Д.Х. Кушинга [1979], а позже В.П. Шунтова [2001; 2016], Л.Б. Кляшторина, А.А. Любушина [2005], В.П. Шунтова, О.С. Темных [2008; 2011].

Необходимо отметить, что многочисленные исследования по динамике численности морских рыб и влияющих на неё факторам в большинстве своём охватывали либо одну локальную популяционную (региональную) группировку (или вид) рыб, либо в таких работах делали обобщения на материале, включающем в себя усреднённые данные по виду (группе видов) в целом. В последнем случае прогнозирование запасов минтая и тихоокеанских лососей по таким материалам [Кляшторин, Любушин, 2005] показало отличные от реальности результаты [Шунтов, 2016]. При этом вполне очевидно, что обилие рыб, обитающих в конкретной акватории, во многом зависит от региональных особенностей абиотических и биотических факторов среды этой акватории или водоёма. Принимая это во внимание, в настоящей работе была сделана попытка оценить воздействие абиотических и прочих факторов (ледовитость, температура воды и воздуха, биомасса зоопланктона, промысел и т.д.) на различные виды и группировки морских рыб с учётом региональных особенностей их распространения. Дополнительно с учётом данных по урожайности поколений рыб представлены материалы по возможной цикличности в обилии рыб.

Целью настоящего исследования является нахождение закономерностей в формировании обилия массовых промысловых рыб дальневосточных морей и прилегающих районов открытой части Тихого океана, а также выявление абиотических, биотических и антропогенных факторов, воздействующих на численность рыб. Для её достижения поставлены следующие задачи: 
- выделение доминирующих по биомассе и вылову видов и группировок промысловых морских рыб и выявление долговременной динамики их обилия;

- нахождение закономерностей формирования биомассы доминирующих видов и группировок рыб с учётом данных по урожайности поколений;

- определение абиотических, биотических и антропогенных факторов с целью оценки степени их воздействия на обилие морских рыб;

- установление возможности использования многофакторного влияния природной среды на обилие морских рыб в целях прогнозирования их уловов.

\section{МАТЕРИАЛ И МЕТОДИКА}

В исследовании задействованы материалы по таким значимым для рыболовства в дальневосточных морях и прилегающих районах открытой части Тихого океана видам рыб как минтай, треска, навага Eleginus gracilis (Tilesius, 1810), терпуги ceверный однопёрый Pleurogrammus monopterygius (Pallas, 1810) и южный однопёрый P. azonus Jordan \& Metz, 1913, камбалы желтопёрая Limanda aspera Pallas, 1814 и двухлинейная Lepidopsetta polyxystra Orr \& Matarese, 2000, сельдь тихоокеанская и тихоокеанские лососи (горбуша Oncorhynchus gorbuscha
(Walbaum, 1792), кета O. keta (Walbaum, 1792), нерка O. nerka (Walbaum, 1792), кижуч O. kisutch (Walbaum, 1792), чавыча O. tshawytscha (Walbaum, 1792)). Эти объекты исторически имели важное промысловое значение для рыболовства в районе исследований, что позволило получить долговременные данные по их биомассе и вылову. Морские рыбы представлены в пределах видов 28 группировками (популяциями), единицами запасов на промысле. Тихоокеанские лососи 5 видов по причине отсутствия достоверных материалов по их численности из многочисленных нерестовых водоёмов рассматриваются 10 группировками, локализованными у западной Камчатки и северо-восточного побережья Камчатки и Чукотки. Суммарный вылов указанных выше гидробионтов, к примеру, в 2018 г. в российских водах Дальневосточного рыбохозяйственного бассейна составил 2716 тыс. т, или $78 \%$ от всего вылова морских рыб (ещё 1371 тыс. т было поймано минтая и сельди в восточной части Берингова моря американской стороной), что указывает на высокую научную и практическую значимость прогнозирования их уловов. Распространение анализируемых рыб приурочено к определённым акваториям дальневосточных морей и прилегающей к ним части Тихого океана

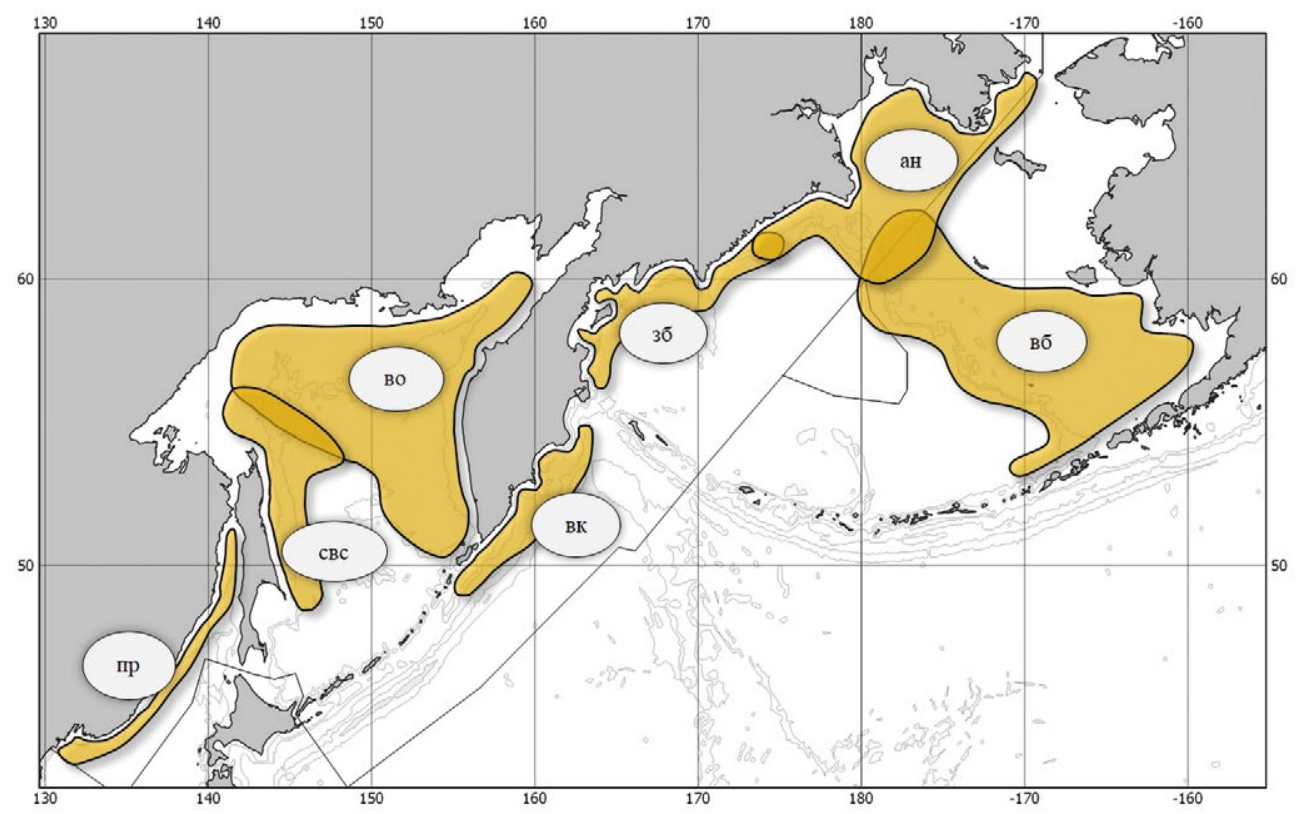

Рис. 1. Карта-схема расположения основных группировок (единиц запасов) минтая в дальневосточных морях, тихоокеанских водах Камчатки и северных Курильских островов. Обозначения группировок (даны в порядке убывания среднемноголетнего вылова за последние 20 лет): вб - восточноберинговоморская (уловы в зоне США), во - восточноохотоморская, ан анадырско-наваринская, вк - восточнокамчатская, зб - западноберинговоморская, свс - северо-восточный Сахалин, пр Японское море (Приморье)

Fig. 1. Map of the location of the main groups (stock units) of walleye pollock in the Far Eastern seas, Pacific waters of Kamchatka and the northern Kuril Islands. The designations of the groupings (given in descending order of the average longterm catch over the last 20 years): вб - East Bering Sea (catches in the US zone), во - East Okhotsk, aн - Anadyr-Navarinsky, вк - East Kamchatka, зб - West Bering Sea, свс - northeastern Sakhalin, пр - Sea of Japan (Primorye) 


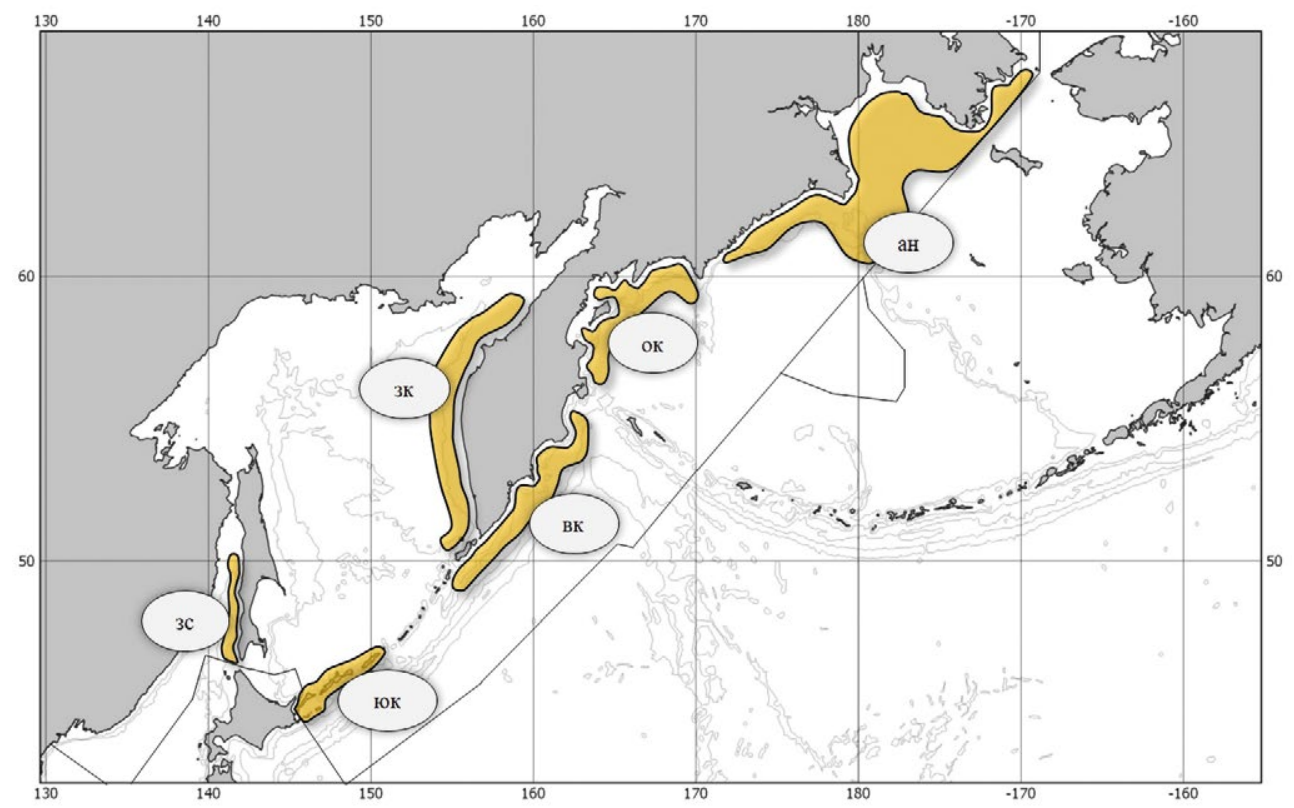

Рис. 2. Карта-схема расположения основных группировок (единиц запасов) трески в дальневосточных морях, тихоокеанских водах Камчатки, северных и южных Курильских островов. Обозначения группировок (даны в порядке убывания среднемноголетнего вылова за последние 20 лет): ан - анадырско-наваринская, вк - восточнокамчатская, ок - олюторскокарагинская (карагинская), зк - западнокамчатская, юк - южнокурильская, зс - западносахалинская

Fig. 2. Map of the location of the main groups (stock units) of Pacific cod in the Far Eastern seas, the Pacific waters of Kamchatka, the northern and southern Kuril Islands. The designations of the groupings (given in descending order of the average long-term catch over the last 20 years): aH - Anadyr-Navarinsky, BK - East Kamchatka, oK - Olyutor-Karaginsky (Karaginsky), 3K - West Kamchatka, юк - South Kuril, зc - West Sakhalin

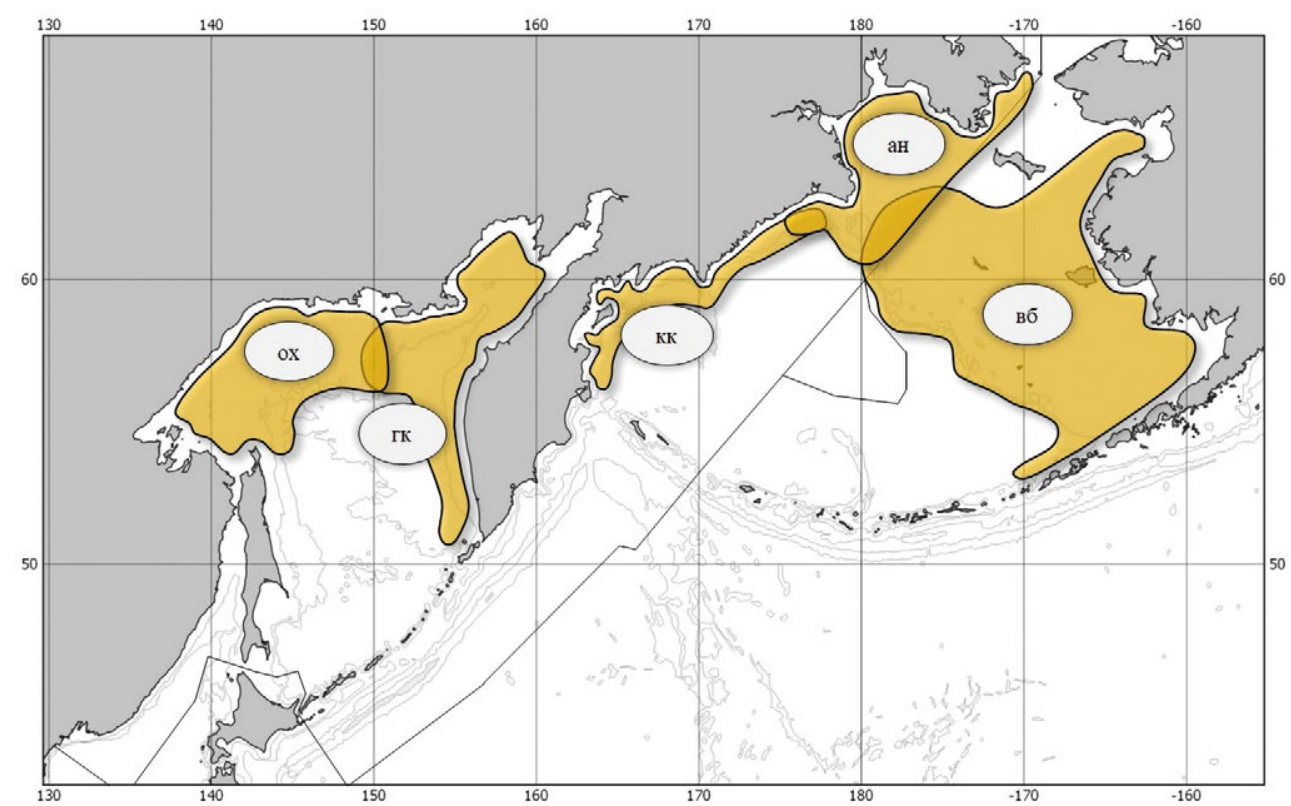

Рис. 3. Карта-схема расположения основных группировок (единиц запасов) тихоокеанской сельди в Охотском и Беринговом морях. Обозначения группировок (даны в порядке убывания среднемноголетнего вылова за последние 20 лет): ох охотская, ан - анадырская (учтены уловы восточноберинговоморской сельди в зоне РФ), кк - корфо-карагинская, вб восточноберинговоморская (уловы в зоне США), гк - гижигинско-камчатская

Fig. 3. Map of the location of the main groups (stock units) of the Pacific herring in the Sea of Okhotsk and the Bering Sea. The designations of the groupings (given in descending order of the average long-term catch over the past 20 years): ox - Okhotsk, ан - Anadyr (catches of East Bering Sea herring in the RF zone are taken into account), кк - Korf-Karaginsky, вб - East Bering Sea (catches in the US zone), гк - Gizhiginsky-Kamchatka 


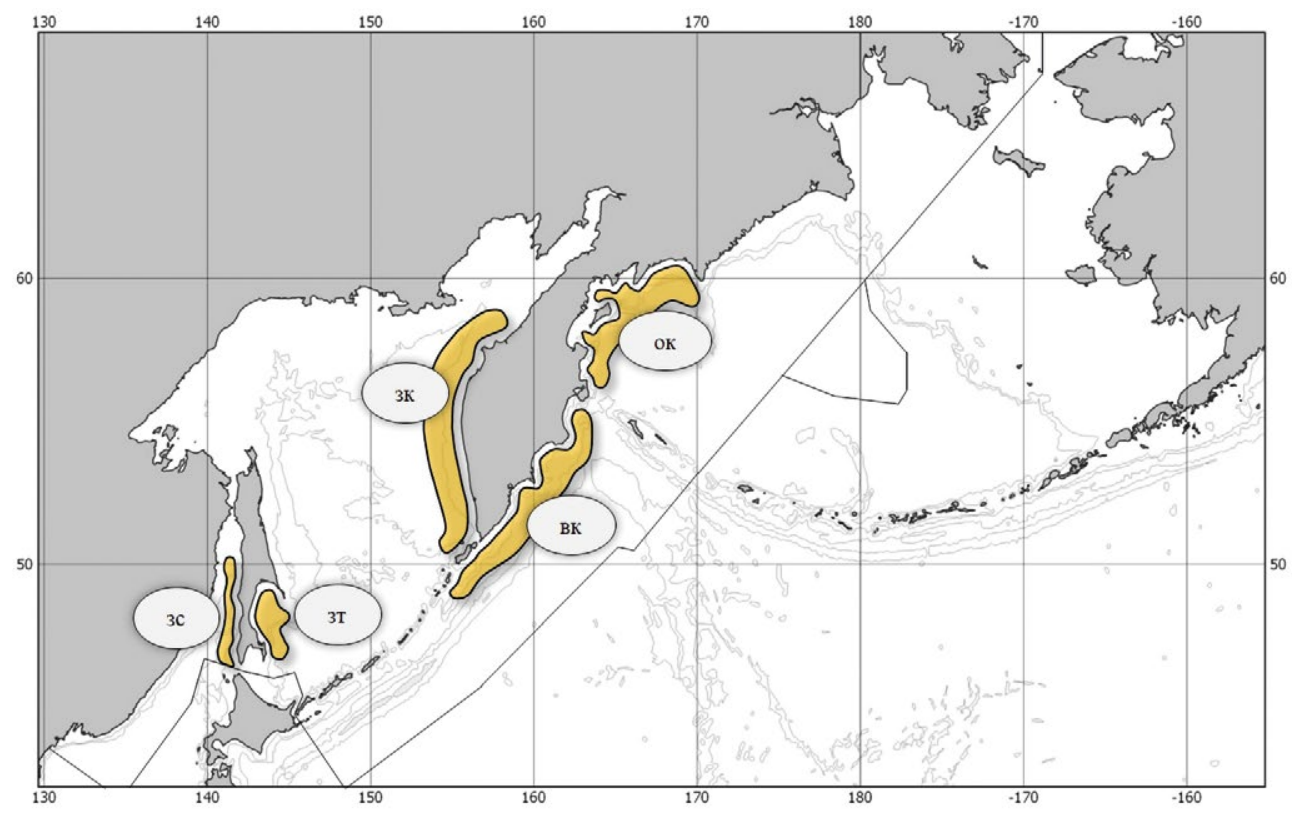

Рис. 4. Карта-схема расположения основных группировок (единиц запасов) камбал в дальневосточных морях, тихоокеанских водах Камчатки и северных Курильских островов. Обозначения группировок (даны в порядке убывания среднемноголетнего вылова за последние 20 лет): зк - желтопёрая западнокамчатская, вк - северная двухлинейная восточнокамчатская, ок - желтопёрая олюторско-карагинская (карагинская), зт - желтопёрая залива Терпения (юговосточный Сахалин), зс - желтопёрая западносахалинская

Fig. 4. Map of the location of the main groups (stock units) of flounders in the Far Eastern seas, Pacific waters of Kamchatka and the northern Kuril Islands. The designations of the groupings (given in descending order of the average long-term catch over the last 20 years): $3 \mathrm{~K}$ - yellowfin sole of West Kamchatka, BK - northern rock sole of East Kamchatka, ok - yellowfin sole of Olutorsk-Karaginsky (Karaginsky), зт - yellowfin sole of Terpeniya Bay (southeastern Sakhalin), 3C - yellowfin sole of West Sakhalin

и показано на рис. 1-6. В качестве уточнения отметим, что популяционный статус рыб и их границы приведены с учётом существующих на настоящий момент времени знаний и в некотором роде условны (отсутствует генетическая идентификация), зачастую отражая границы промысловых районов.

В работе использованы ряды данных по биомассам морских рыб, полученных из следующих источников: по минтаю [Николаев, Степаненко, 2001; Степаненко, 2001а, б; Борец и др., 2002; Булатов, 2004; 2014; Бабаян и др., 2006; Датский, Андронов, 2007; Буслов, 2008; Антонов, 2011; Овсянников, 2011; lanelli et al., 2013; 2018; Ильин и др., 2014; Степаненко, Грицай, 2016; Вдовин и др., 2017; Охотоморский..., 2017], треске [Антонов, 2011; 2013; Золотов и др., 2013], наваге [Антонов, 2011; Золотов и др., 2013], терпугам [Антонов, 2011; Золотов и др., 2015; Золотов, Фатыхов, 2016], камбалам [Тарасюк, 1997; Золотов, 2008; 2009; Антонов, 2011; Золотов и др., 2014; Антонов, Кузнецова, 2018] и сельди [Шунтов и др., 1993; Фархутдинов, 2005; Антонов и др., 2016; Лобода, Жигалин, 2017; Ormseth, 2019]. Для корректного сопоставления величин обилия биомасса минтая из юго-восточной части Берингова моря пересчитана с учётом коэффи- циентов уловистости тралов: для молоди - 0,1; для взрослых рыб - 0,4 [Макрофауна..., 2012].

Многолетние материалы по вылову представлены в следующих публикациях: по минтаю [Фадеев, Веспестад, 2001; Степаненко, Николаев, 2005; Антонов, 2011; lanelli et al., 2013; 2018; Шевченко, Датский, 2014; Вдовин и др., 2017], треске [Промысел..., 1988; Балыкин, 2006; Антонов, 2011; 2013], наваге [Балыкин, 2006; Новикова, 2007; 2014; Антонов, 2011], терпугам [Антонов, 2011; Золотов и др., 2015; Золотов, Фатыхов, 2016], камбалам [Тарасюк, 1997; Золотов, 2008; 2009; Антонов, 2011; Золотов и др., 2014] и сельди [Антонов и др., 2016; Лобода, Жигалин, 2017]. Данные по вылову тихоокеанских лососей взяты с сайта NPAFC [www.npafc.org.].

Опубликованные материалы по биомассам и выловам морских рыб были дополнены результатами исследований, полученными дальневосточными научно-исследовательскими институтами на современном этапе (до 2020 г. включительно). Вылов морских рыб также анализировали по данным оперативной отчёт-

1 Промысел трески в северо-западной части Тихого океана и перспективы его развития. 1988. Промежуточный научный отчёт / исп. А.М. Орлов. М.: ВНИРО. 73 с. 


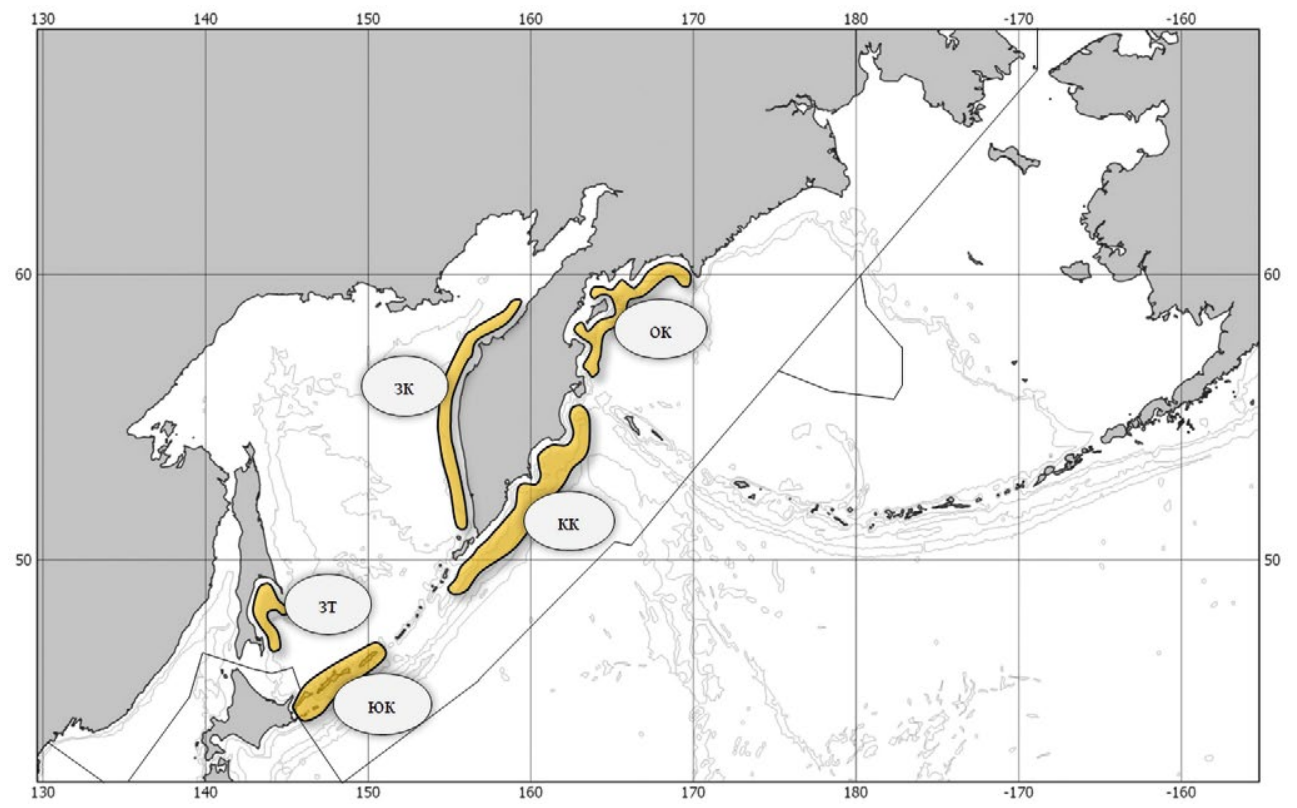

Рис. 5. Карта-схема расположения основных группировок (единиц запасов) наваги и терпугов в дальневосточных морях, тихоокеанских водах Камчатки, северных и южных Курильских островов. Обозначения группировок (даны в порядке убывания среднемноголетнего вылова за последние 20 лет): кк - терпуг северный однопёрый юго-восточной Камчатки и северных Курильских островов (курило-камчатская), зк - навага западнокамчатская, зт - навага залива Терпения (юговосточный Сахалин), ок - навага олюторско-карагинская (карагинская), юк - терпуг южный однопёрый южных Курильских островов

Fig. 5. Map of the location of the main groups (stock units) of saffron cod and greenlings in the Far Eastern seas, the Pacific waters of Kamchatka, the northern and southern Kuril Islands. The designations of the groupings (given in descending order of the average long-term catch over the last 20 years): KK - Atka mackerel of southeastern Kamchatka and northern Kuril Islands (Kuril-Kamchatka), зк - saffron cod of West Kamchatka, зт - saffron cod of Terpeniya Bay (southeastern Sakhalin), ok - saffron cod of Olutorsk-Karaginsky (Karaginsky), юк - Okhotsk atka mackerel of the southern Kuril Islands

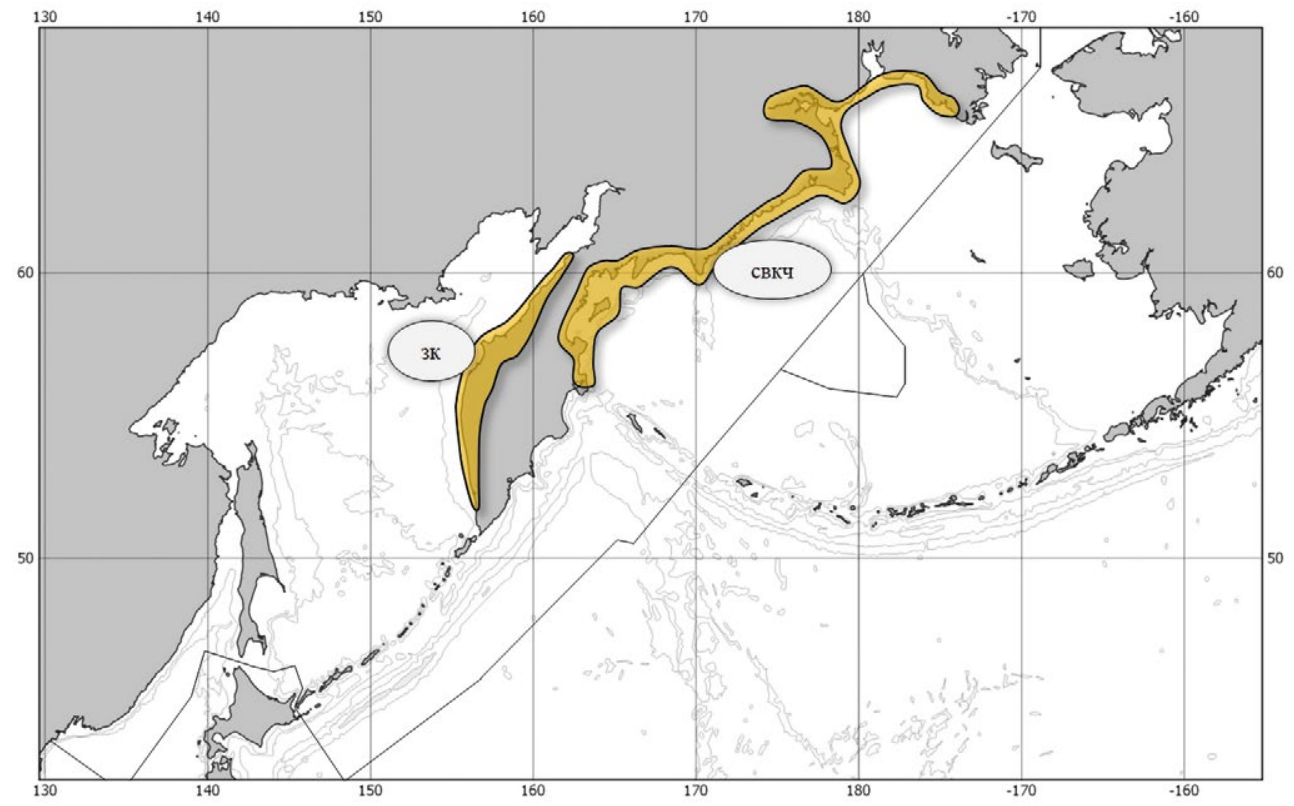

Рис. 6. Карта-схема расположения районов промысла и нереста тихоокеанских лососей у западного побережья Камчатки (зк) и северо-восточного побережья Камчатки и Чукотки (свкч)

Fig. 6. Map of the location of Pacific salmon fishing and spawning areas off the west coast of Kamchatka (3К) and the northeast coast of Kamchatka and Chukotka (свкч) 
ности предприятий, отраслевой системы мониторинга. Для доступа и первичной обработки использовали программу «FMS analyst» [Vasilets, 2015]. Использованные материалы по биомассам и уловам морских рыб из указанных выше источников приведены для сравнительного анализа в виде графиков.

Формирование максимумов биомассы морских рыб во многом обусловлено, помимо различного воздействия факторов природной среды, появлением высокочисленных поколений. Для этой цели проанализированы многочисленные научные публикации по урожайности поколений отдельных видов и группировок и показано влияние таких генераций на обилие рыб. Отметим здесь, что воздействие высокоурожайных поколений хорошо заметно на протяжении жизни морских рыб, которая в основном не превышает 25-30 лет у отдельных видов, в среднем составляя 7-15 лет. К примеру, тихоокеанские лососи охвачены промыслом в основном до 7-летнего возраста, навага и терпуги - до 7-8 лет, треска и минтай - до 8-9 лет, тихоокеанская сельдь - до 10-11 лет, желтопёрая камбала - до 14-15 лет, двухлинейная камбала - до 17-18 лет [Науменко, 2001; Датский, Андронов, 2007; Антонов, 2011]. При этом возраст рыб, когда в их биомассе заметно проявляются поколения повышенной численности, изменяется от 1 до 8 лет, а наибольший прирост биомассы, за редким исключением, приходится на 3-6 годы в зависимости от вида.

В рамках обнаружения исходных абиотических и биотических факторов, оказывающих потенциальное влияние на биомассу анализируемых рыб, привлечены многолетние данные изменчивости природной среды [Лучин, 2008; Фигуркин и др., 2008; Хен и др., 2008; 2009; Дьяков Б.С., 2010; Пищальник и др., 2016; 2020; Плотников, Вакульская, 2012; Кузнецов и др., 2013; Волков, 2014; Шунтов, 2016; Беринговоморская..., 2017; Вдовин и др., 2017; Siddon, Zador, 2017; Горбатенко, 2018; Дальневосточное УГМС ${ }^{2}$ ]. По причине многочисленности и протяжённости по времени этот материал представлен в программе для управления библиографической информацией Mendeley [Datsky et al., 2021]. Данные по факторам среды синхронизированы с периодом, когда имелась достоверная информация по биомассе и вылову массовых промысловых видов рыб, а также по урожайности их поколений.

Совпадения флуктуаций в динамике обилия рыб, а также их противофазность [Волвенко, 2014], объясняются биотическими и абиотическими факторами, среди которых особый интерес представляют клима-

\footnotetext{
2 Дальневосточное УГМС. Доступно через: www.khabmeteo.ru, http://meteo-dv.ru/geospace/AverageMonthW. 09.09.2001.
}

тические индексы, эффекты от которых могут проявляться с большим запаздыванием, что даёт опору для долгосрочного прогнозирования [Кляшторин, Любушин, 2005]. Ранее нами предпринимались попытки описать вероятные связи изменений численности рыб с абиотическими факторами классическими статистическими методами, например, параметрической корреляцией по Пирсону или непараметрической по Спирмену [Кулик, 2007]. Недостаток такого анализа заключается в его неспособности объективно выделять нелинейные, периодические связи, а также связи, выраженные не через одну, а через множество функций. Особую сложность для выделения представляют последние, т.к. зачастую они, являясь суперпозицией нескольких функций, не могут быть выражены через одну. Они же являются наиболее интересными с биологической точки зрения, т.к. многофакторные связи в природе встречаются чаще, чем однофакторные, и их совместные эффекты могут быть не только аддитивными, но и мультипликативными, например, синергетическими или ингибирующими друг друга. В таком случае множественный регрессионный анализ усложняется даже в случае всего двух ковариатов и требует тщательного отбора кандидатов в предикторы или их представлений в динамическом факторном анализе [Large et al., 2015].

Следовательно, выбор потенциальных предикторов должен быть максимально объективным. Это значит, что мера сходства рядов наблюдений должна равнозначно оценивать различные функциональные (линейные, нелинейные, в т.ч. периодические) и нефункциональные связи с равным шумом. Таким свойством обладает максимальный информационный коэффициент - МИК [Reshef et al., 2011; 2014]. В линейных зависимостях он приближается к квадрату корреляции Пирсона или коэффициенту детерминации, но в отличие от последнего, не занижает меру сходства в нелинейных и более сложных (составных или смешанных) зависимостях и интерпретируется в том же интервале 0-1, где 0 обозначает отсутствие зависимости, а 1 - максимально тесную связь. Так, квадраты корреляций Пирсона и Спирмена (далее - обычные корреляции) в синусоидальных и параболических зависимостях примерно равны 0, а МИК - 1 [Reshef et al., 2011]. Таким образом, ориентируясь на низкие значения коэффициентов обычных корреляций можно пропустить фактически детерминированные зависимости. Однако находимые высокие значения МИК при низких значениях корреляций вычленяют и более сложные смешанные зависимости, которые могут возникать в результате опосредованного влияния скрытых факторов. Это приводит к неочевидной связи 
на графиках динамики рядов с высоким МИК. Более того, строгое соответствие объективности данного коэффициента и в линейных связях не считается математически доказанным [Kinney, Atwal, 2014]. В то же время подчёркивается [Reshef et al., 2014], что объективность МИК основана не на математических доказательствах, а на статистических выводах, полученных в результате проведения множества симуляций, в которых альтернативные обычным корреляциям меры сходства существенно проигрывали МИК.

Следуя вышесказанному, сила связи между предиктором (например, ледовитость) и предиктантом (биомасса или вылов) измерялась через максимальный информационный коэффициент (далее - МИК). Она оценивалась как без сдвига рядов, так и со сдвигом потенциального предиктора в прошлое до 5 лет. Эти сдвиги предполагают, что вероятный эффект от изменения указанной выше ледовитости мог иметь наибольшую силу в год рождения особей, т.е. в прошлом относительно суммарных биомасс и уловов. Допускается, что за пять лет рыбы должны были набрать достаточную массу, чтобы проявиться в динамике биомассы или уловов. Связи без задержки представляют интерес как потенциальные предикторы перераспределения рыб, влияющие на их доступность для облова на промысле или во время проведения научных съёмок.

Расчёты МИК произведены с применением языка программирования R и пакета Minerva для коротких рядов [Albanese et al., 2012]. Демонстрация варианта задействования сильных найденных зависимостей проведена с использованием обобщённых аддитивных моделей - OAM [Wood et al., 2015] в пакете mgcv с выбором оптимальной по информационному критерию при настройке с максимальным правдоподобием, а финальная настройка осуществлена по более надёжному, но неподходящему для сравнений по информационным критериям, методу ограниченного маргинального правдоподобия [Wood, 2011]. Отличие ОАМ от обобщённых линейных моделей (ОЛМ), заключается в добавлении к линейному предиктору части, аппроксимирующей нелинейные связи, например, сплайнами [Hastie, Tibshirani, 1990]. В нашем случае использовали тонкоплёночные регрессионные сплайны [Wood, 2003].

\section{РЕЗУЛЬТАТЫ И ОБСУЖДЕНИЕ}

Долговременные исходные данные по различным факторам природной среды являются основой для выявления закономерностей формирования обилия морских рыб. Связь воздействия среды и численности рыб не всегда отчётливо выражена и зачастую неод- нозначна в силу большого количества промежуточных факторов [Колесник, 2002а, б; Кулик, 2009], влияющих на климат и биоту и действующих одновременно. В то же время это влияние существует и во многом достоверно проявляется не только на глобальных совокупностях, но и на мелких, региональных группировках с более тонкими настройками факторов природной среды [Колесник, 2002б]. В этой связи, прежде чем говорить о потенциальном влиянии факторов среды на обилие морских рыб Северной Пацифики необходимо кратко охарактеризовать динамику их запасов.

Наибольшие биомассы среди рыб в районе исследований формируют минтай и сельдь (рис. 7 а), пелагические виды, образовывающие промысловые скопления и в придонных слоях. Максимальное обилие сельди наблюдалось в 1950-1960-е и 2010-е гг. Некоторый рост её биомассы отмечался и в 1983-1986 и 1997-2002 гг., однако в целом с 1970 по 2009 гг. выявлено сравнительно невысокое обилие этого вида. Повышенная суммарная биомасса минтая, наоборот, была высока в 1980-е гг., и, в меньшей степени, в 1990-е и 2010-е гг. Периоды с середины 1960-х до начала 1980-х гг. и с середины 1990-х гг. до 2010 г. характеризовались существенно меньшим его обилием. Сходную с минтаем динамику биомасс показывали треска и навага (рис. 7 б), с той лишь разницей, что максимумы их обилия смещены на 1990-е и 2010-е гг. Наибольшая биомасса желтопёрой камбалы отмечена в 1950-е и 1980-1990-е гг., северного однопёрого терпуга - в 1998-2009 гг. (рис. 7 б).

Уловы горбуши, кеты и нерки у западного и северо-восточного побережий Камчатки и Чукотки планомерно возрастали с 1980-х гг. и достигли максимума в 2010-х гг. Динамика их обилия в основном развивалась сходным образом, за исключением снижения вылова горбуши в 2013-2015 гг. (рис. 8). Напротив, в этот период отмечен рост уловов кижуча, который после минимума вылова в 1990-е гг., с 2007 г. показывает существенную положительную динамику на промысле. Уловы чавычи всегда были невысоки, достигнув в 2000-х гг. минимальных значений.

Общая динамика обилия анализируемых видов естественным образом не отражает флюктуации численности отдельных группировок морских рыб, вследствие региональных особенностей исследуемых акваторий и различающихся условий обитания рыб в них. Так, в 1970-е гг. наблюдались довольно высокие биомассы западноберинговоморской и восточнокамчатской популяций минтая, рыб у северо-восточного Сахалина и Приморья. В 1980-е гг. наибольшие значения обилия показали восточно-, западноберинговоморская и восточноохотоморская группировки, а также 
ДИНАМИКА ОБИЛИЯ МАССОВЫХ ПРОМЫСЛОВЫХ РЫБ ДАЛЬНЕВОСТОЧНЫХ МОРЕЙ И ПРИЛЕГАЮЩИХ РАЙОНОВ ОТКРЫТОЙ ЧАСТИ ТИХОГО ОКЕАНА И ВЛИЯЮЩИЕ НА НЁ̈ ФАКТОРЫ
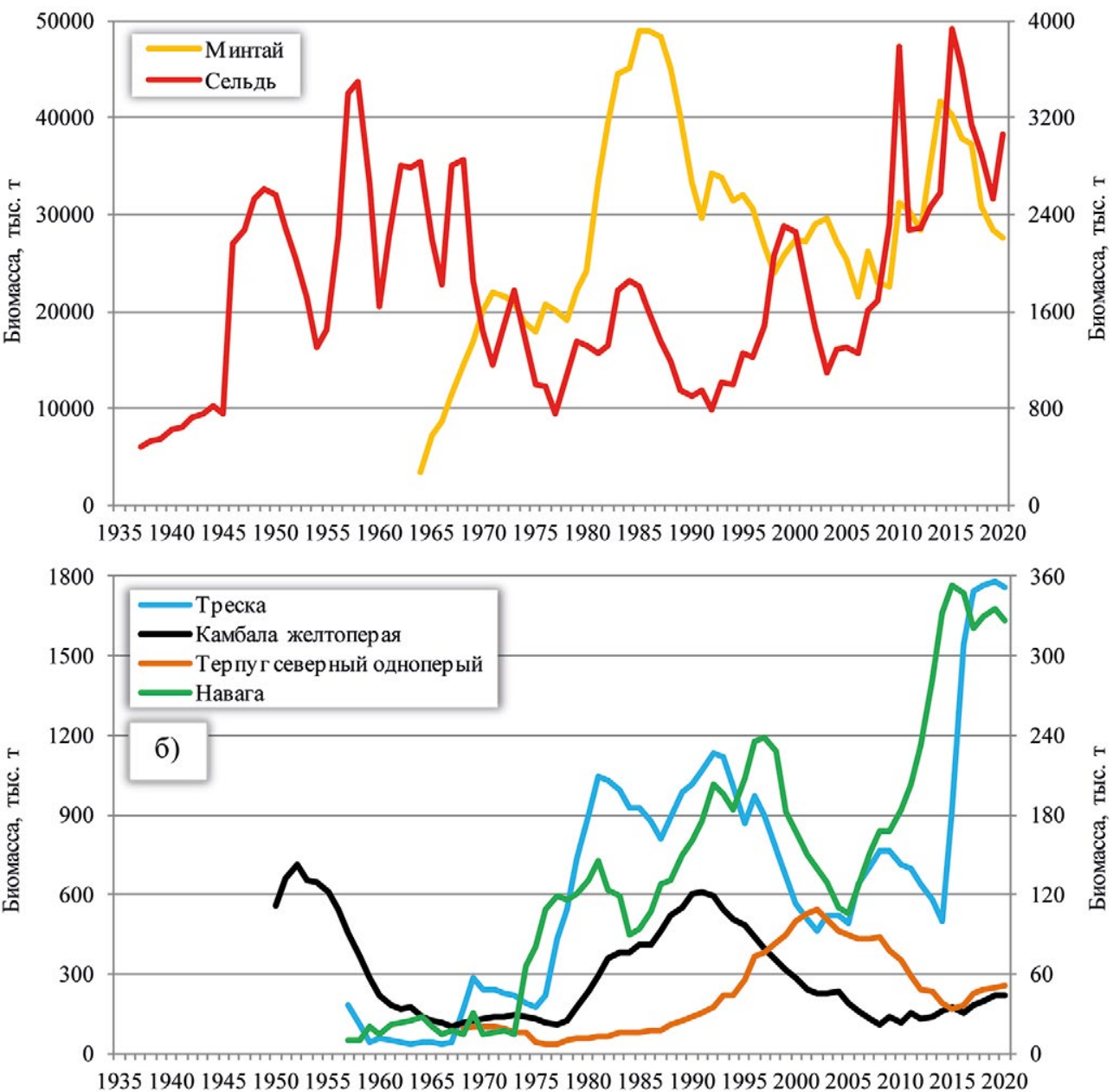

Рис. 7. Суммарная биомасса (тыс. т) массовых промысловых рыб в дальневосточных морях, тихоокеанских водах Камчатки и северных и южных Курильских островов в 1937-2020 гг.: а - минтай (левая шкала), сельдь (правая шкала); б - треска (левая шкала), прочие виды (правая шкала)

Fig. 7. Total biomass (thousand tons) of commercial fish in the Far Eastern seas, the Pacific waters of Kamchatka and the northern and southern Kuril Islands in 1937-2020. a - walleye pollock (left vertical scale), Pacific herring (right); 6 - Pacific cod (left scale), other species (right scale)
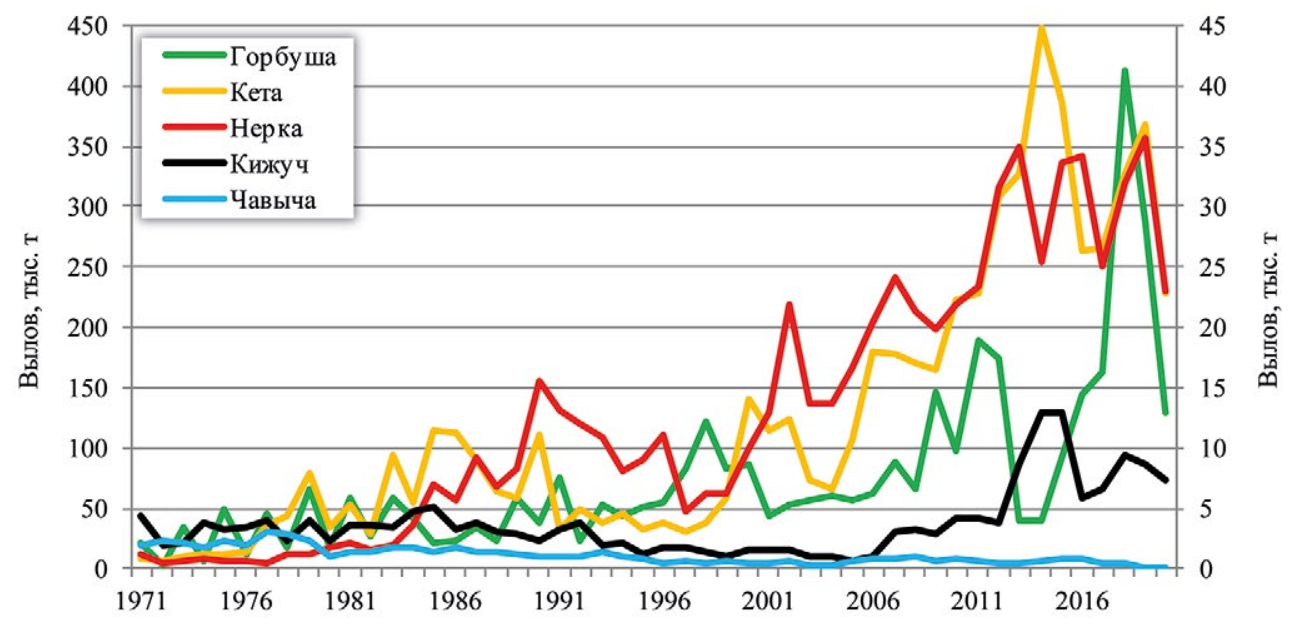

Рис. 8. Суммарный вылов (тыс. т) тихоокеанских лососей у западного и северо-восточного побережья Камчатки и Чукотки в 1971-2020 гг.: горбуша (левая шкала), прочие виды (правая шкала)

Fig. 8. Total catch (thousand tons) of Pacific salmon off the western and northeastern coast of Kamchatka and Chukotka in 1971-2020: pink salmon (left vertical scale), other species (right scale) 
ANDREY V. DATSKY, VLADIMIR V. KULIK, SOFIA A. DATSKAYA

THE DYNAMICS OF THE ABUNDANCE OF COMMERCIAL FISH IN THE FAR EASTERN SEAS AND ADJACENT AREAS OF THE OPEN PART OF THE PACIFIC OCEAN AND FACTORS INFLUENCING IT
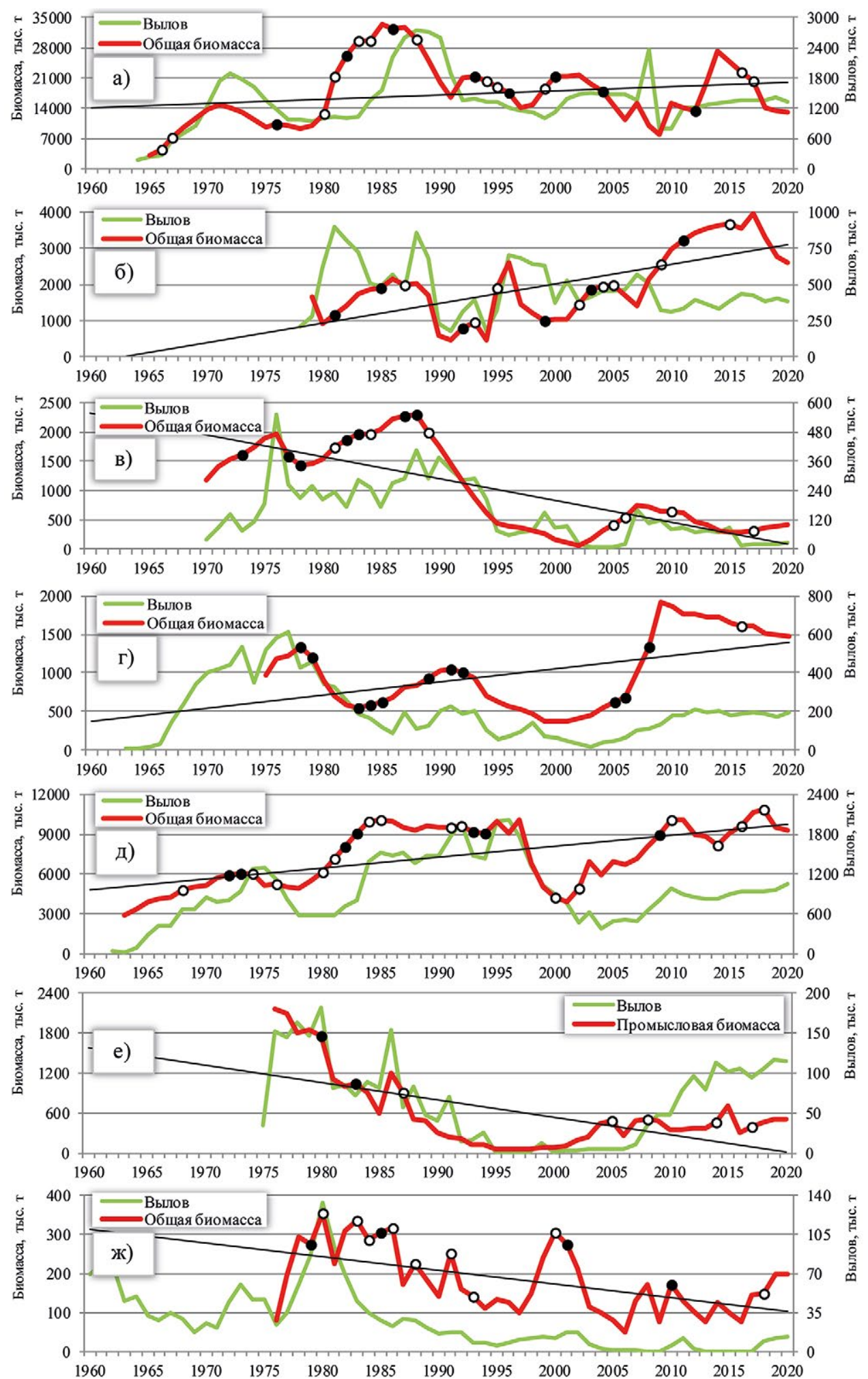

Рис. 9. Биомасса и вылов (тыс. т) группировок минтая в дальневосточных морях, тихоокеанских водах Камчатки и северных Курильских островов: а - восточноберинговоморская, б - анадырско-наваринская, в - западноберинговоморская, г восточнокамчатская, д - восточноохотоморская, е - минтай северо-восточного Сахалина, ж - минтай Японского моря (Приморье). Кружками (чёрные - суперурожайные, белые - урожайные) показано влияние на биомассу рыб поколений высокой численности, прямыми линиями - тренд изменения биомассы

Fig. 9. Biomass and catch (thousand tons) of walleye pollock groups in the Far Eastern seas, Pacific waters of Kamchatka and the northern Kuril Islands. a - East Bering Sea, 6 - Anadyr-Navarinsky, в - West Bering Sea, г - East Kamchatka, д - East Okhotsk Sea, e - northeastern Sakhalin, $*$ - Sea of Japan (Primorye). The circles (black - super yielding, white - yielding) show the effect of generations of high abundance on the biomass of fish, straight lines - the trend of biomass change 


\section{А.В. ДАТСКИЙ, В.В. КУЛИК, С.А. ДАТСКАЯ}

ДИНАМИКА ОБИЛИЯ МАССОВЫХ ПРОМЫСЛОВЫХ РЫБ ДАЛЬНЕВОСТОЧНЫХ МОРЕЙ И ПРИЛЕГАЮЩИХ РАЙОНОВ ОТКРЫТОЙ ЧАСТИ ТИХОГО ОКЕАНА И ВЛИЯЮЩИЕ НА НЕЁ ФАКТОРЫ

приморский минтай. Относительно высокая биомасса в 1990-е гг. была замечена только у минтая северо-восточной части Охотского и северо-западной части Берингова морей. С начала 2000-х гг. и по настоящий момент максимальное обилие данного вида выявлено у анадырско-наваринской, восточнокамчатской и восточноохотоморской группировок, прочие популяции, за исключением рыб из восточной части Берингова моря, находятся на своём минимуме (рис. 9). В целом общий тренд на увеличение обилия за весь период наблюдений отмечается у восточноберинговоморской, анадырско-наваринской, восточнокамчатской и восточноохотоморской группировок минтая, у остальных биомасса имеет тенденцию к снижению (табл. 1).

Таблица 1. Общая характеристика обилия основных промысловых рыб в дальневосточных морях, тихоокеанских водах Камчатки и северных и южных Курильских островов в 1937-2020 гг.

Table 1. General characteristics of the abundance of the main commercial fish in the Far Eastern seas, Pacific waters of Kamchatka and the northern and southern Kuril Islands in 1937-2020

\begin{tabular}{|c|c|c|c|c|}
\hline Вид, группировка & $\begin{array}{c}\text { Период } \\
\text { исследований }\end{array}$ & $\begin{array}{l}\text { Тренд изменения } \\
\text { биомассы (вылова) }\end{array}$ & $\begin{array}{c}\text { Среднее значение биомассы / } \\
\text { вылова (пределы), тыс. т }\end{array}$ & $\begin{array}{c}\text { Периоды биомассы (вылова) } \\
\text { выше среднего значения }\end{array}$ \\
\hline $\begin{array}{l}\text { Минтай восточноберингово- } \\
\text { морский (США) }\end{array}$ & $1965-2020$ & Повышение & $17318,5(3225-33425)$ & $\begin{array}{l}\text { 1981-1990, } 1992-1996,1999- \\
2004,2013-2017\end{array}$ \\
\hline $\begin{array}{l}\text { Минтай восточноохотомор- } \\
\text { ский }\end{array}$ & $1963-2020$ & Повышение & $7386,7(2950-10900)$ & $1982-1997,2008-2020$ \\
\hline $\begin{array}{l}\text { Минтай анадырско-наварин- } \\
\text { ский }\end{array}$ & $1979-2020$ & Повышение & $1990,1(445-3970)$ & $\begin{array}{l}1986,1988-1996,2005,2008- \\
2020\end{array}$ \\
\hline $\begin{array}{l}\text { Минтай западноберингово- } \\
\text { морский }\end{array}$ & $1970-2020$ & Снижение & $1017,1(63-2306)$ & 1970-1992 \\
\hline Минтай восточнокамчатский & $1975-2020$ & Повышение & $1006,5(373-1917)$ & $\begin{array}{l}1976-1979,1990-1992,2009- \\
2020\end{array}$ \\
\hline $\begin{array}{l}\text { Минтай северо-восточного } \\
\text { Сахалина }\end{array}$ & $1976-2020$ & Снижение & $596,7(50-2150)$ & 1976-1987, 2015 \\
\hline $\begin{array}{l}\text { Минтай Японского моря } \\
\text { (Приморье) }\end{array}$ & $1976-2020$ & Снижение & $179,7(48-355)$ & $\begin{array}{l}\text { 1977-1989, 1991, 1999-2002, } \\
2019,2020\end{array}$ \\
\hline $\begin{array}{l}\text { Треска анадырско-наварин- } \\
\text { ская }\end{array}$ & $1968-2020$ & Повышение & $326,0(12-1470)$ & $2007-2011,2015-2020$ \\
\hline Треска западнокамчатская & $1957-2020$ & Повышение & $171,1(35-440)$ & $1957,1972,1978-2000$ \\
\hline Треска карагинская & $1970-2020$ & Снижение & $132,9(25-350)$ & $\begin{array}{l}1978-1986,1988-1996,1999, \\
2005\end{array}$ \\
\hline Треска восточнокамчатская & $1977-2020$ & Снижение & $98,9(38-274)$ & $1979-1990$ \\
\hline Треска южнокурильская & $1981-2020$ & Снижение & $44,3(27-86)$ & $1981-1989,2017,2019-2020$ \\
\hline Треска западносахалинская & $1983-2020$ & Снижение & $18,1(6-37)$ & $1983-1992,2017-2020$ \\
\hline Навага карагинская & $1974-2020$ & Повышение & $74,8(26-215)$ & $1980-1983,2010-2020$ \\
\hline Навага западнокамчатская & $1957-2020$ & Повышение & $62,9(4-178)$ & $1990-2001,2007-2020$ \\
\hline $\begin{array}{l}\text { Навага залива Терпения } \\
\text { (вост. Сахалин) }\end{array}$ & $1974-2020$ & Снижение & $27,0(16-50)$ & $\begin{array}{l}1976-1981,1986-1989,1995- \\
2003,2010\end{array}$ \\
\hline $\begin{array}{l}\text { Терпуг северн. однопёрый } \\
\text { вост. Камчатки, сев. Курил }\end{array}$ & $1968-2020$ & Повышение & $222,6(35-545)$ & $1995-2013,2017-2020$ \\
\hline $\begin{array}{l}\text { Терпуг южный однопёрый } \\
\text { южных Курил }\end{array}$ & $1977-2020$ & На одном уровне & $13,0(2-38)$ & $\begin{array}{l}1977-1980,1996-2005,2011- \\
2013\end{array}$ \\
\hline $\begin{array}{l}\text { Камбала двухлинейная } \\
\text { восточнокамчатская }\end{array}$ & $1955-2020$ & Повышение & $48,4(20-94)$ & $1955-1960,1983-2004,2018$ \\
\hline $\begin{array}{l}\text { Камбала желтопёрая западно- } \\
\text { камчатская }\end{array}$ & $1950-2020$ & Снижение & $226,1(44-570)$ & $1950-1958,1981-1998$ \\
\hline $\begin{array}{l}\text { Камбала желтопёрая кара- } \\
\text { гинская }\end{array}$ & $1951-2020$ & Снижение & $30,6(9-71)$ & $\begin{array}{l}1951-1958,1982-1986,1990- \\
2002,2007-2008\end{array}$ \\
\hline $\begin{array}{l}\text { Камбала желтопёрая залива } \\
\text { Терпения (вост. Сахалин) }\end{array}$ & $1950-2020$ & Повышение & $28,3(8-47)$ & $\begin{array}{l}1950-1967,1990-1997,2009- \\
2018\end{array}$ \\
\hline $\begin{array}{l}\text { Камбала желтопёрая западно- } \\
\text { сахалинская }\end{array}$ & $1950-2020$ & Снижение & $10,7(4-45)$ & $1950-1966$ \\
\hline Сельдь охотская & $1946-2020$ & Повышение & $913,5(70-2271)$ & $\begin{array}{l}1946-1952,1963-1965,1967- \\
1969,1972-1974,1984-1985 \\
2005,2007-2020\end{array}$ \\
\hline
\end{tabular}


ANDREY V. DATSKY, VLADIMIR V. KULIK, SOFIA A. DATSKAYA

THE DYNAMICS OF THE ABUNDANCE OF COMMERCIAL FISH IN THE FAR EASTERN SEAS AND ADJACENT AREAS OF THE OPEN PART OF THE PACIFIC OCEAN AND FACTORS INFLUENCING IT

Окончание табл. 1

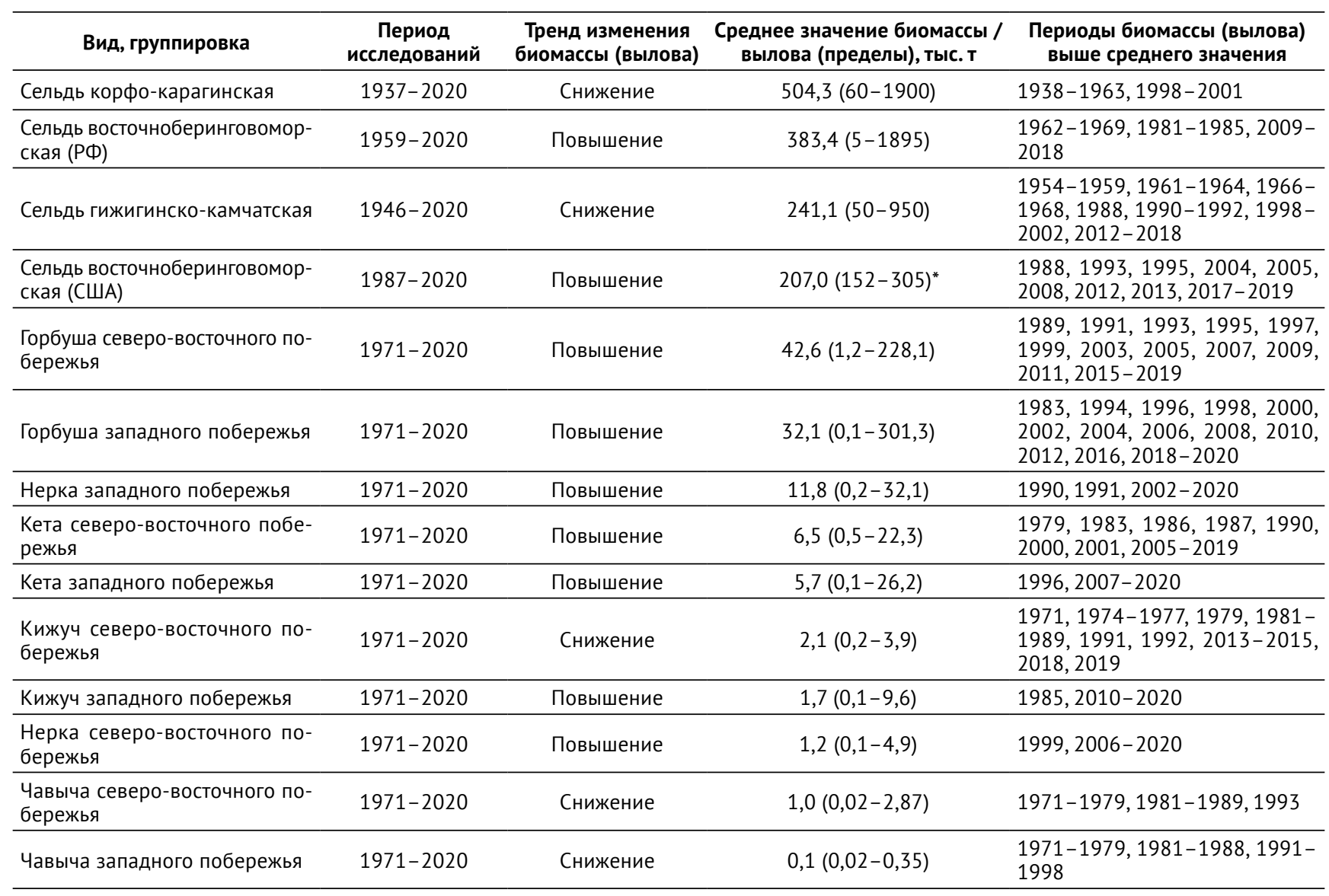

Примечание: У тихоокеанских лососей анализировали уловы, у прочих рыб - биомассу; * данные за период с 2000 по 2015 гг.

У трески самый длинный ряд наблюдений выявлен для западнокамчатской группировки, биомасса которой планомерно увеличивалась с начала 1960 х гг., достигнув максимальных значений в 1990-е гг. Сходная динамика обилия отмечена и для карагинской трески. Напротив, популяции трески восточнокамчатской, южнокурильской и западносахалинской формировали пики биомасс в 1980-е гг. В начале 2000-х гг. высоких значений биомассы трески по району исследований не наблюдалось, за исключением увеличения в 2007-2010 гг. запасов анадырско-наваринской и южнокурильской группировок. И только в 2015-2020 и 2016-2020 гг. соответственно в анадырско-наваринском районе Берингова моря и у берегов западного Сахалина обилие этого вида тресковых рыб резко возросло (рис. 10). В целом, за весь период исследований выявлена тенденция роста биомассы трески северо-западной части Берингова моря и западной Камчатки, у прочих группировок отмечено снижение запасов (табл. 1).

Из рассмотренных трёх популяций наваги две (карагинская и западнокамчатская) обнаруживают постепенный рост биомассы, одна (у восточного Сахалина) - снижение (табл. 1, рис. 11). При этом у берегов северо-восточной Камчатки данный вид формировал пики обилия в конце 1970-х - начале 1980-х и в 2010-е гг., у западной Камчатки - в 1990-е и 2010-е гг. У восточного Сахалина максимумы обилия рыб примерно в схожих масштабах (за исключением 2000-х гг.) наблюдались в середине каждого десятилетия.

Два вида однопёрых терпугов (северный и южный) с середины 1980-х гг. показывали сходную динамику биомасс с максимумом в 2000-2004 гг. При этом первый вид, в основном обитающий у берегов юго-восточной Камчатки и северных Курильских островов, несмотря на постепенное снижение в 2000е гг., все же обнаруживает общий рост обилия. Второй вид, живущий у южных Курильских островов, за счёт высокой биомассы в середине 1970-х гг. не показывает тенденций к снижению или росту запасов (табл. 1, рис. 12). Надо отметить, что камчатско-курильская популяция северного однопёрого терпуга имеет обширное распространение, но районы обитания рыб весьма обособлены [Золотов и др., 2015]. Поэтому не исключено, что продолжительный максимум биомассы данной популяции в 1995-2011 гг. вполне мог 
А.В. ДАТСКИЙ, В.В. КУЛИК, С.А. ДАТСКАЯ

ДИНАМИКА ОБИЛИЯ МАССОВЫХ ПРОМЫСЛОВЫХ РЫБ ДАЛЬНЕВОСТОЧНЫХ МОРЕЙ И ПРИЛЕГАЮЩИХ РАЙОНОВ ОТКРЫТОЙ ЧАСТИ ТИХОГО ОКЕАНА И ВЛИЯЮЩИЕ НА НЕЁ ФАКТОРЫ
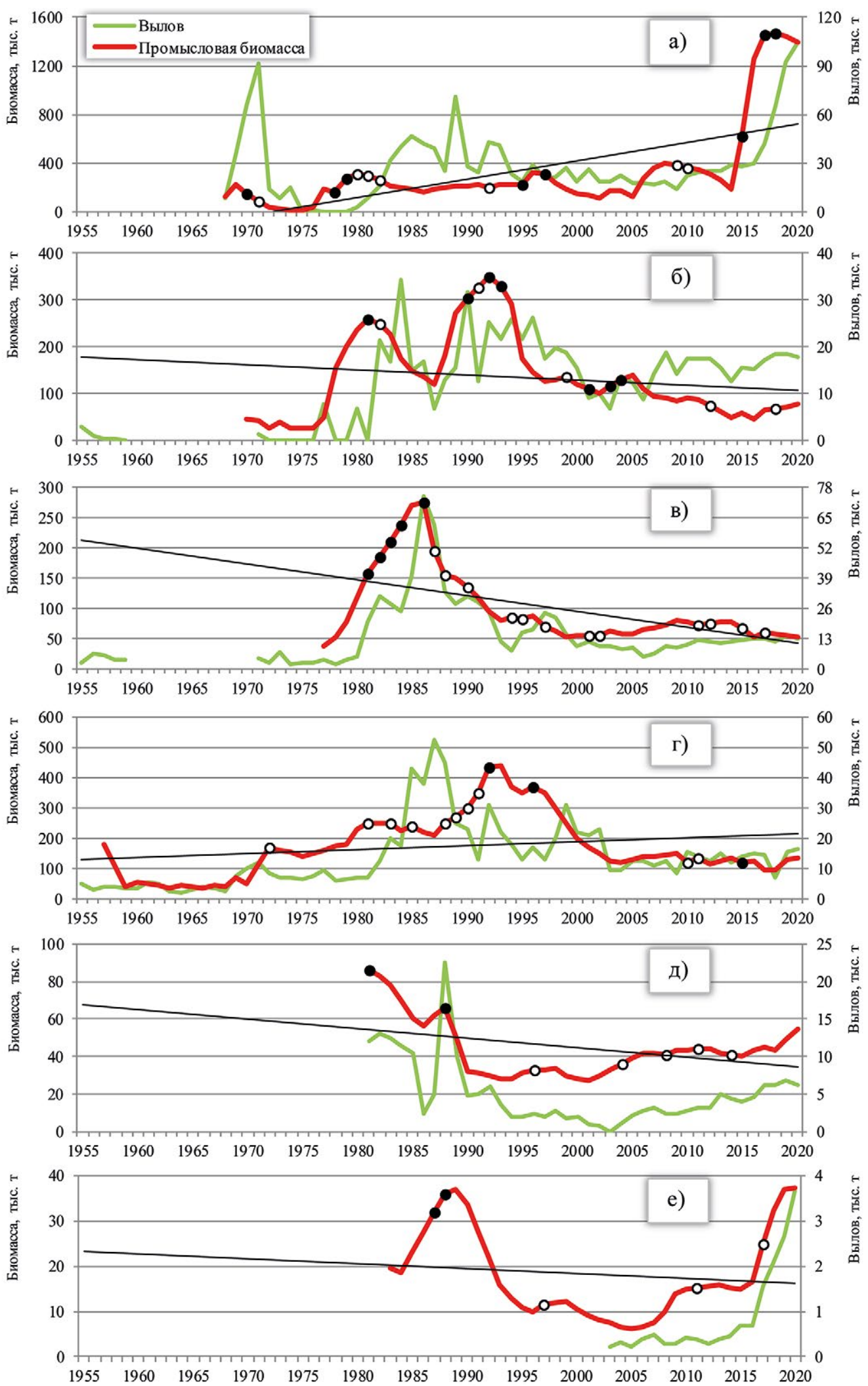

Рис. 10. Промысловая биомасса и вылов (тыс. т) группировок трески в дальневосточных морях, тихоокеанских водах Камчатки, северных и южных Курильских островов: а - анадырско-наваринская, б - карагинская, в - восточнокамчатская, г - западнокамчатская, д - южнокурильская, е - западносахалинская. Обозначения как на рис. 9

Fig. 10. Biomass and catch (thousand tons) of Pacific cod groups in the Far Eastern seas, the Pacific waters of Kamchatka, the northern and southern Kuril Islands. a - Anadyr-Navarinsky, 6 - Karaginsky, в - East Kamchatka, $г$ - West Kamchatka, д - South Kuril, e - West Sakhalin. Designations as in figure 9 
ANDREY V. DATSKY, VLADIMIR V. KULIK, SOFIA A. DATSKAYA

THE DYNAMICS OF THE ABUNDANCE OF COMMERCIAL FISH IN THE FAR EASTERN SEAS AND ADJACENT AREAS OF THE OPEN PART OF THE PACIFIC OCEAN AND FACTORS INFLUENCING IT
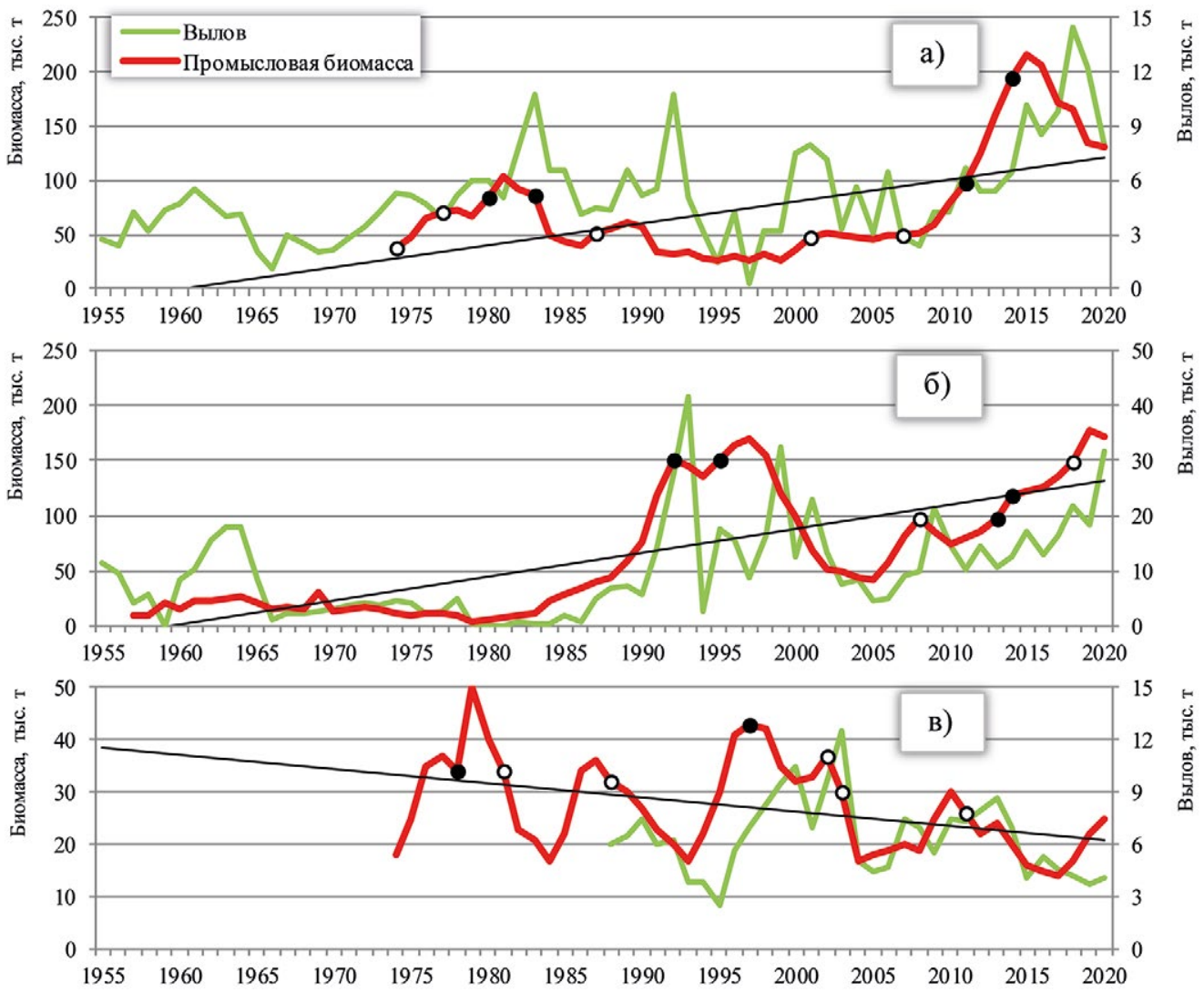

Рис. 11. Промысловая биомасса и вылов (тыс. т) группировок наваги в дальневосточных морях: а - карагинская, б западнокамчатская, в - навага залива Терпения (юго-восточный Сахалин). Обозначения как на рис. 9

Fig. 11. Biomass and catches (thousand tons) of saffron cod groups in the Far Eastern seas. a - Karaginsky, 6 - western Kamchatka, в - Terpeniya Bay (southeastern Sakhalin). Designations as in figure 9
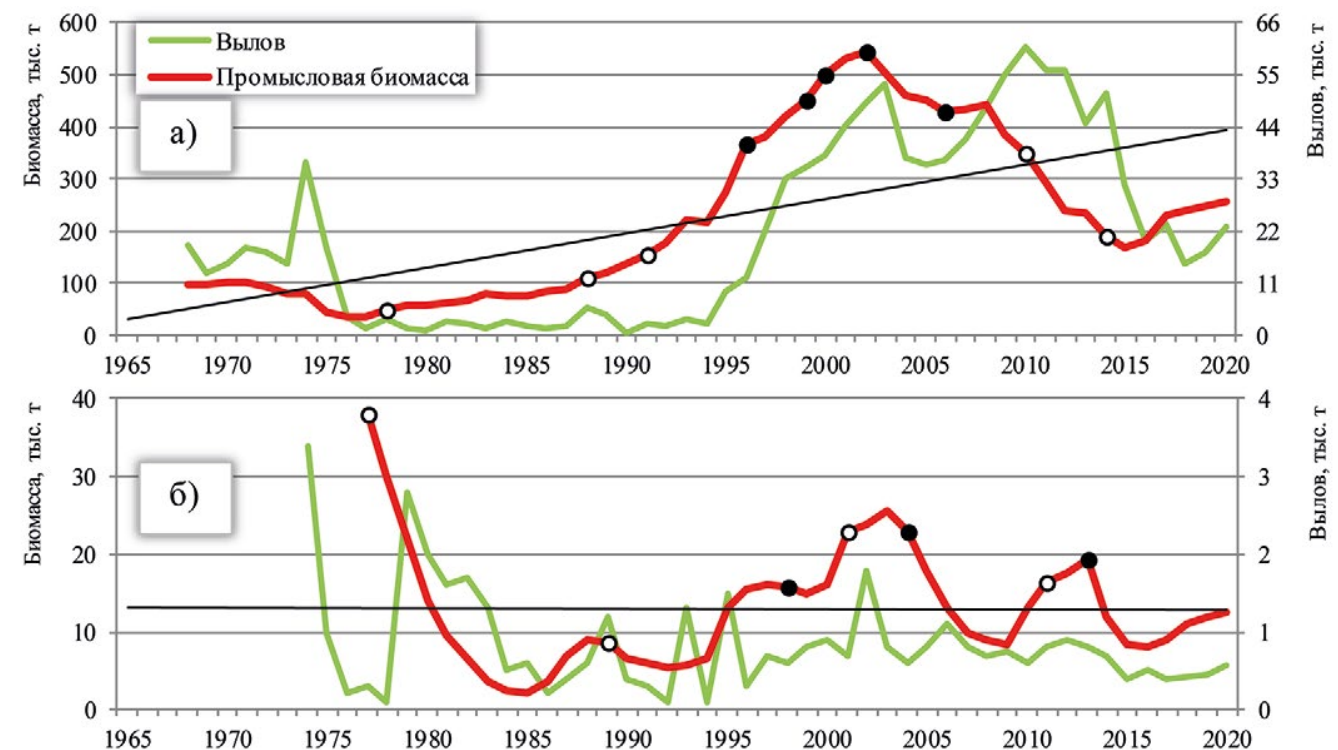

Рис. 12. Промысловая биомасса и вылов (тыс. т) северного однопёрого (а) и южного однопёрого (б) терпугов в дальневосточных морях, тихоокеанских водах Камчатки, северных и южных Курильских островов. Обозначения как на рис. 9

Fig. 12. Biomass and catch (kt) of Atka mackerel (a) and Okhotsk atka mackerel (б) in the Far Eastern seas, Pacific waters of Kamchatka, northern and southern Kuril Islands. Designations as in figure 9 

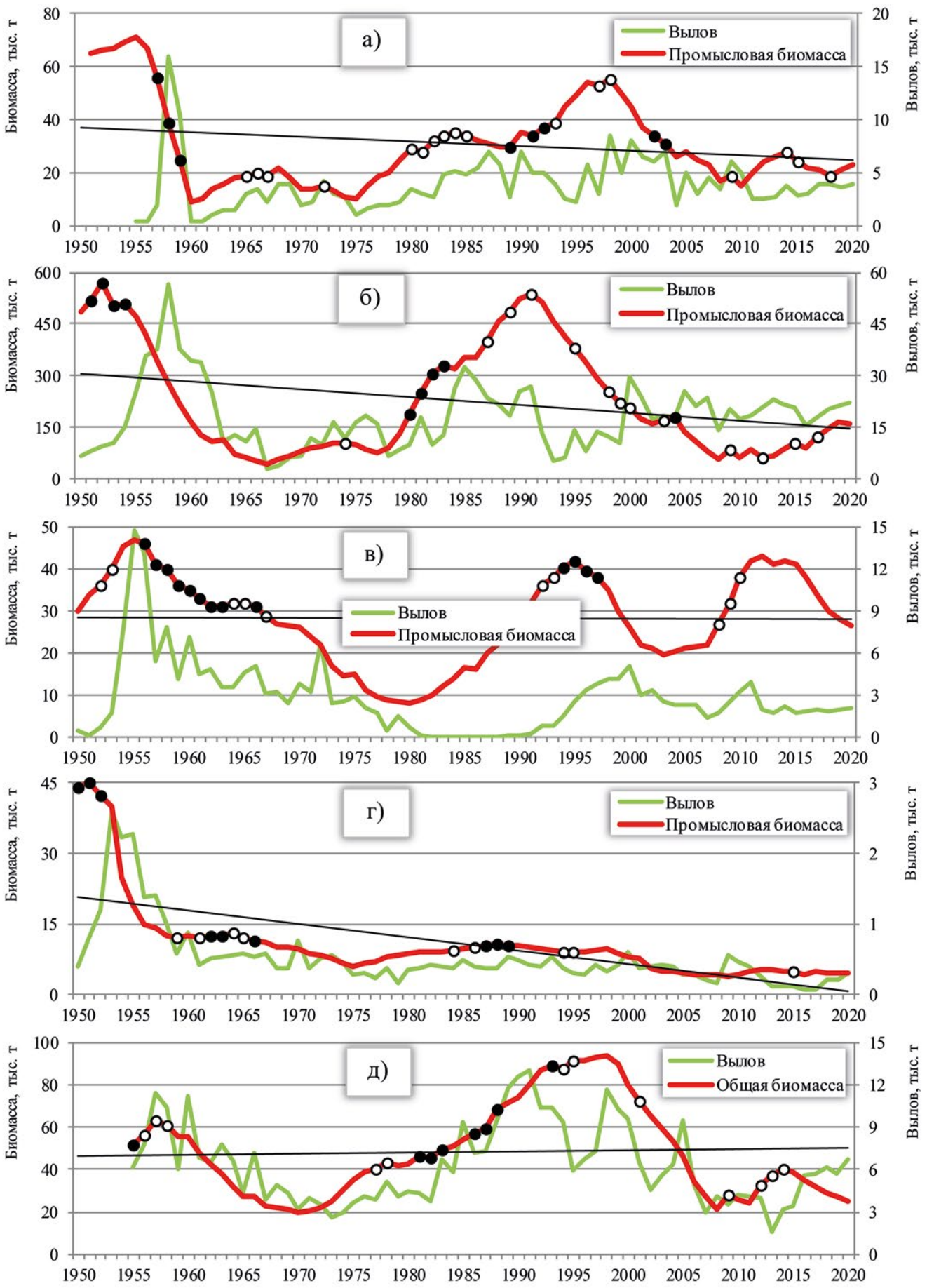

Рис. 13. Биомасса и вылов (тыс. т) группировок желтопёрой (а-г) и двухлинейной (д) камбал в дальневосточных морях, тихоокеанских водах Камчатки и северных Курильских островов: а - желтопёрая карагинская, б - желтопёрая западнокамчатская, в - желтопёрая залива Терпения (юго-восточный Сахалин), г - желтопёрая западносахалинская, д северная двухлинейная восточнокамчатская. Обозначения как на рис. 9

Fig. 13. Biomass and catch (thousand tons) of groups of yellowfin sole (a-r) and northern rock sole (д) in the Far Eastern seas, Pacific waters of Kamchatka and the northern Kuril Islands. a - yellowfin sole of Karaginsky, $\sigma$ - yellowfin sole of Western Kamchatka, в - yellowfin sole of Terpeniya Bay (southeastern Sakhalin), г - yellowfin sole of West Sakhalin, д - northern rock sole of East Kamchatka. Designations as in figure 9

быть сформирован из разнонаправленной динамики обилия отдельных групп рыб, образующих скопления у мысов, островов и в проливах юго-восточной
Камчатки и северных Курильских островов. Однако материалы по уловам и обилию данного терпуга, изначально собранные с локальных акваторий, как пра- 
вило, усредняются исследователями, исходя из соображения, что популяция является единицей промысла.

Желтопёрая камбала формировала наибольшую биомассу в 1950-е и 1980-1990-е гг. После 1950-х гг. пики биомассы западнокамчатской, восточносахалинской и карагинской группировок наблюдались соответственно в начале, середине и конце 1990-х гг. В 1980-е гг. обилие этого вида было высоким только у западного и северо-восточного побережий Камчатки. С начала 2000-х гг. биомасса всех группировок желтопёрой камбалы, за исключением рыб у восточного Сахалина, снизилась и на настоящий момент находится на сравнительно низком уровне. Ещё у одно- го вида камбал - северной двухлинейной, набольшие скопления выявлены у берегов юго-восточной Камчатки в 1950-е и 1980-1990-е гг. Причём, этот вид, наряду с желтопёрой камбалой залива Терпения, обнаруживает небольшой положительный тренд изменения обилия за счёт роста биомассы с 2012 г. (табл. 1, рис. 13).

Если рассматривать биомассу сельди, то можно заметить её высокую биомассу в 1940-1960-х и 2000-х гг. Напротив, с конца 1970-х по конец 1990-х гг., когда наблюдался рост обилия тресковых рыб, сельдь имела сравнительно низкие запасы. В то же время динамика биомасс сельди отдельных группировок существенно
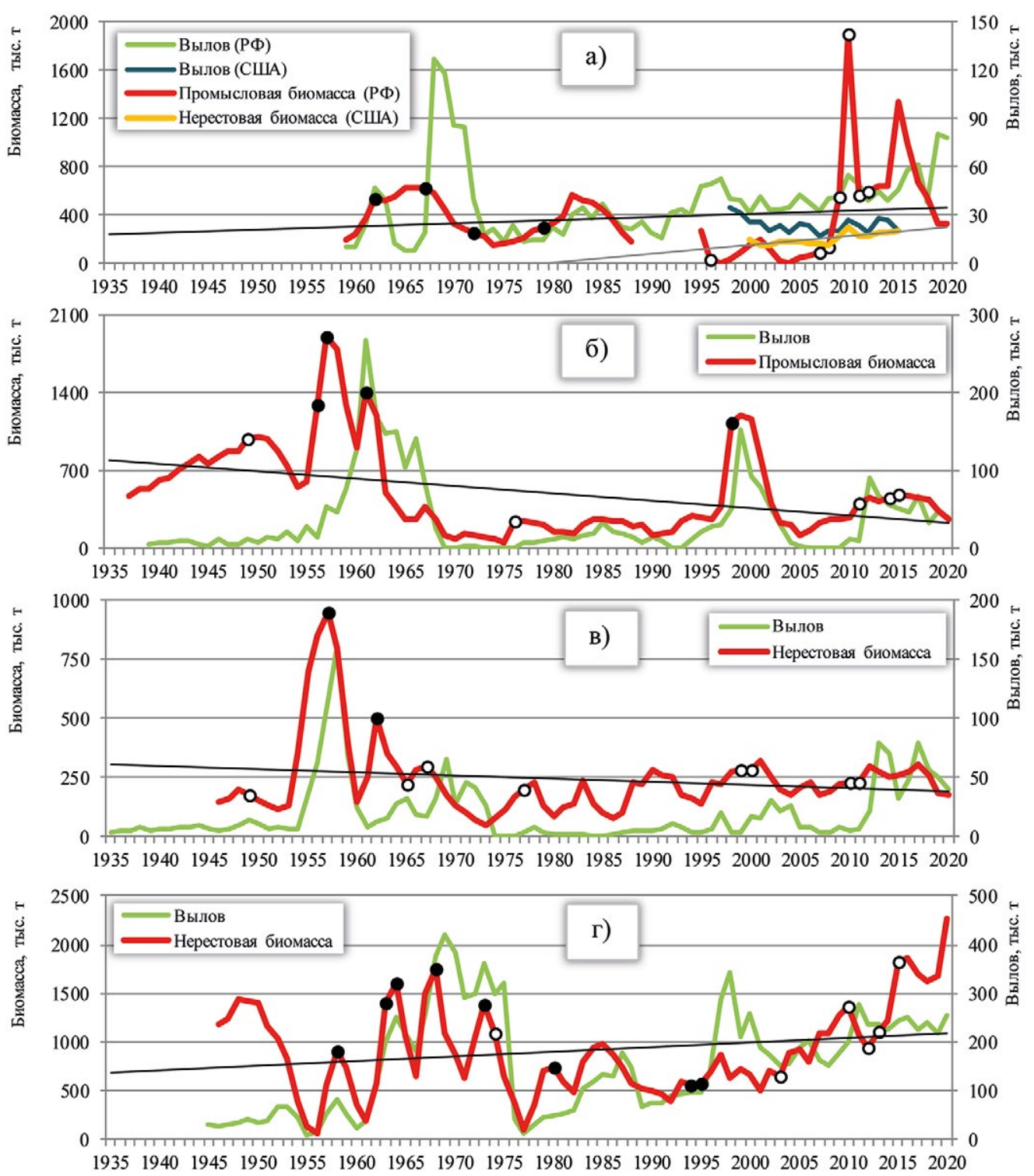

Рис. 14. Биомасса и вылов (тыс. т) популяций тихоокеанской сельди в Беринговом и Охотском морях: а восточноберинговоморская, б - корфо-карагинская, в - гижигинско-камчатская, г - охотская. Обозначения как на рис. 9

Fig. 14. Biomass and catch (thousand tons) of populations of Pacific herring in the Bering and Okhotsk seas. a - East Bering Sea, 6 - Korf-Karaginsky, в - Gizhiginsky-Kamchatka, г - Okhotsk. Designations as in figure 9 
различалась (табл. 1, рис. 14). Так, выявлены синхронные изменения обилия корфо-карагинской и гижигинско-камчатской сельди, наибольшие запасы которых наблюдались в 1950-1960-х и в конце 1990-х начале 2000-х гг. Восточноберинговоморская и охотская сельди обнаруживали схожую динамику обилия между собой с максимумами в 1961-1973 и 20092020 гг. При этом их биомасса была сравнительно высока и в 1980-е гг. Подобную сопряжённость численности сельди вышеуказанных популяций друг с другом, а также с минтаем отмечали и ранее [Науменко, 2001; Балыкин, Золотов, 2010].

Полномасштабный промысел горбуши осуществляется с переменным успехом у западного побережья Камчатки и северо-восточного побережья Камчатского и Чукотского полуостровов. Причём, до 1985 г. уловы вида в обоих районах изменялись синхронно, в последующем - после перестройки в структуре стад западной Камчатки в 1981-1984 гг., запасы рыб изменялись в противофазе. В первом районе численность рыб была высокой в 1990-х и 2007-2011, 20152019 гг., во втором - в середине 1980-х - конце 1990х и 2004-2012, 2016-2020 гг. В целом, исключая аномально низкие уловы горбуши в беринговоморских водах Камчатки и Чукотки в 2012-2014 гг. и у западного побережья Камчатки в 2013-2015 гг., наблюдается общий рост её запасов (табл. 1, рис. 15 а).

Кета у берегов северо-восточной Камчатки и Чукотки заметно выделялась своим обилием с конца 1970-х до начала 1990-х гг., а также в 1999-2002 гг. С 2005 по 2019 гг. наблюдался экстремальный подъём запасов этой региональной группировки вида. У западной Камчатки повышенные уловы кеты отмечены в середине 1980-х и с начала 2000-х гг. по настоящий момент, причём, с 2010 г. её уловы по величине превысили беринговоморские. В целом в изменении обилия этой рыбы с обеих сторон Камчатского полуострова наблюдается определённое сходство с некоторым запаздыванием максимумов вылова на год у группировки, нерестящейся в пределах Охотского моря (табл. 1, рис. 15 б).

У нерки ситуация обратная: по численности и соответственно вылову преобладает группировка западной Камчатки, наибольшие уловы которой отмечены в 1987-1996 гг. и с 2000 г. по настоящее время. Нерка Берингова моря имеет меньшую численность, её повышенное обилие наблюдалось в 1995-2001 и 2006-2020 гг. (табл. 1, рис. 15 в). Определённая синхронность подходов рыб в нерестовые реки в обеих группировках выявлена лишь с 2006 г., до этого они изменялись разнонаправленно. Необходимо отметить, что практически сходная динамика вылова нер- ки в Охотском и Беринговом морях после 2012 г. характеризуется годовым запаздыванием максимумов уловов рыб в последнем районе.

Исторически сложилось, что кижуча облавливали в больших объёмах у северо-восточного побережья Камчатки. Обилие рыб здесь отмечено на высоком уровне в 1970-1994 и 2013-2019 гг. Группировка кижуча в пределах охотоморских вод формировала редкие подъёмы численности в 1984-1985, 19901992 гг. Ситуация изменилась с 2010 г., когда уловы здесь резко возросли и превысили аналогичные показатели беринговоморских рыб. В целом за период наблюдений обилие кижуча в рассматриваемых районах менялось сходным образом, достигнув максимальных величин в 2013-2019 гг. (табл. 1, рис. 15 г).

Чавыча - самый крупный и относительно малочисленный вид тихоокеанских лососей, который добывается приловом к остальным лососям. Основные её уловы приурочены к юго-западной части Берингова моря, где она имела высокую численность в 19701980-х гг. В последующем ежегодный вылов сокращался, достигнув минимума в 2003 г. (табл. 1, рис. 15 д). Некоторый рост обилия чавычи отмечен в 20052016 гг., однако в 2017-2020 гг. ее уловы опять снизились. У западного побережья Камчатки вылов изменялся похожим образом, однако он невелик для корректной интерпретации полученной информации.

Таким образом, в динамике обилия анализируемых морских рыб, наряду с некоторым сходством у ряда видов и популяционных группировок, в отдельные годы отмечены и значимые отличия (рис. 9-15). Обусловлено это, в первую очередь, многофакторным внешним воздействием на рыб различных факторов природной среды, зачастую специфичных в пределах обитания гидробионтов. К примеру, тихоокеанские лососи с обоих побережий Камчатки, за исключением горбуши, в морской период жизни нагуливаются в сходных районах в северо-западной части Тихого океана [Атлас..., 2002]. Однако возвращаясь с нагула в места нереста, а позже молодью скатываясь из рек в море, они попадают в различающуюся природную среду, оказывающую определяющее влияние на их выживание и численность. В качестве примера можно привести ряд публикаций по тихоокеанским лососям [Островский, 2011; 2014; Фельдман, Шевляков, 2015], в которых показан сложный характер влияния факторов среды на численность поколений рыб на фоне внутрипопуляционных особенностей видов. При этом основные причины изменчивости их численности в отдельных водоёмах могут быть сходными, но роль конкретных факторов (сила влияния) специфична для конкретного вида и района воспроизводства. То же 
ANDREY V. DATSKY, VLADIMIR V. KULIK, SOFIA A. DATSKAYA

THE DYNAMICS OF THE ABUNDANCE OF COMMERCIAL FISH IN THE FAR EASTERN SEAS AND ADJACENT AREAS OF THE OPEN PART OF THE PACIFIC OCEAN AND FACTORS INFLUENCING IT
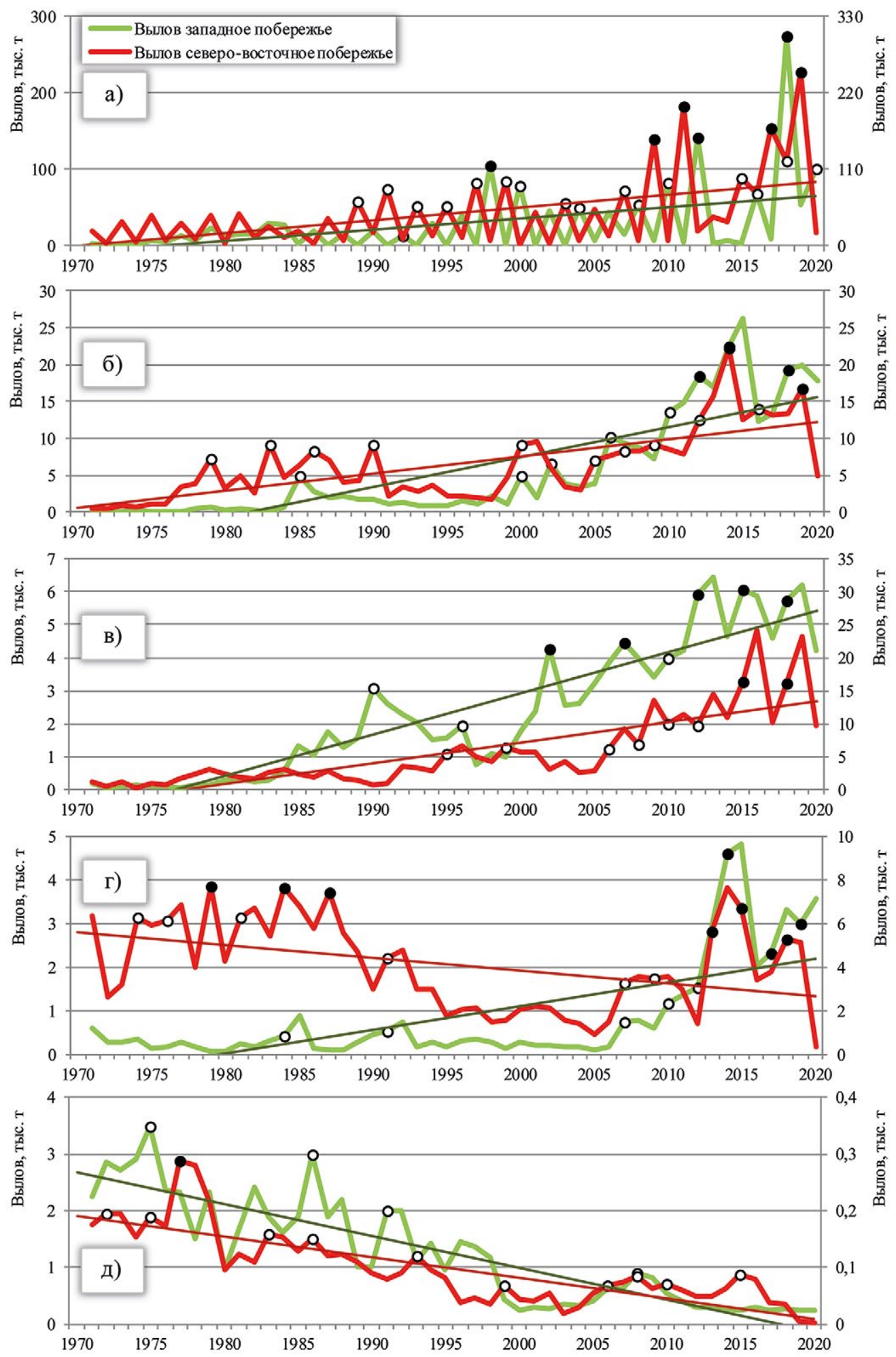

Рис. 15. Вылов (тыс. т) тихоокеанских лососей у западного побережья Камчатки (шкала справа) и северо-восточного побережья Камчатки и Чукотки (шкала слева): а - горбуша, б - кета, в - нерка, г - кижуч, д - чавыча. Кружками (чёрные суперурожайные, белые - урожайные) показано влияние на обилие рыб поколений высокой численности, прямыми линиями - тренды изменения уловов

Fig. 15. Catches (thousand tons) of Pacific salmon off the western coast of Kamchatka and the northeastern coast of Kamchatka and Chukotka. a - pink salmon, 6 - chum salmon, в - sockeye salmon, $\mathbf{r}$ - coho salmon, д - chinook salmon. The circles (black - super yielding, white - yielding) show the effect of generations of high abundance on the abundance of fish, straight lines - trends in catches 
можно сказать и про других морских рыб, которые, не имея столь своеобразного жизненного цикла, также обитают в нестабильных условиях среды, весьма различающихся в ходе нагульных, нерестовых и зимовальных миграций видов.

Очевидно, что наиболее уязвимы (высокая естественная смертность) рыбы на ранних стадиях развития (личинки, сеголетки и годовики). В пределах первого года жизни молодь переходит на другой тип питания, у неё обозначаются смена биотопов и расширение ареалов с соответствующей адаптацией к новым условиям среды, включая повышенное давление хищников. Как правило, именно в годовалом возрасте закладывается будущая численность рыб, важность учёта особей этой возрастной категории отражена рядом исследователей [Дементьева, 1961; Науменко, 2001; Максименков, 2002; Балыкин, 2006]. Высокочисленные поколения рыб, обнаружившие себя на стадии сеголеток и годовиков, в дальнейшем даже при неблагоприятных условиях среды их обитания, как правило, преобладают в уловах и, достигнув половой зрелости, формируют основу для успешного и, в некоторых случаях, долговременного промысла. Другой особенностью появления урожайных поколений является их цикличность, которая у каждого вида или популяции имеет свою периодичность.

В этой связи для морских рыб, по которым имелись долговременные данные по биомассам (общей, промысловой или нерестовой), были найдены встречающиеся в научной литературе упоминания о появлении урожайных поколений. В общей сложности привлечены данные 380 поколений 27 запасов рыб (табл. 2). С учётом информации о возрасте рыб, в котором они начинают проявлять себя заметным увеличением биомассы, такие генерации впоследствии отмечали на графиках долговременных рядов обилия (рис. 9-14). К примеру, пик биомассы у корфо-карагинской сельди в 1998-2000 гг. преимущественно сформирован урожайным поколением 1993 г. [Науменко, 2001; Шунтов, 2016], у западноберинговоморского минтая генерациями 2001, 2002, 2006 гг. обеспечено высокое обилие рыб в 2008-2011 гг., а у минтая восточной Камчатки поколениями 2000, 2001, 2003 гг. - в 2009-2012 гг. [Антонов, 2011].

Для тихоокеанских лососей, в силу скудности исходных данных об урожайных поколениях, численность генераций определялась предположительно, исходя из среднего возраста массового захода рыб в реки на нерест, значимого увеличения их уловов (за счёт влияния высокочисленных поколений) в конкретные годы и среднемноголетнего тренда уловов лососей (табл. 1). Учитывая, что рассматриваемые группировки рыб сформированы производителями из многочисленных рек западного и северо-восточного побережий Камчатки и Чукотки, а также тот факт, что тихоокеанские лососи (за исключением горбуши), имеют сложную возрастную структуру, были проанализированы опубликованные материалы с целью выявления преобладающих в уловах возрастных классов рыб из различных нерестовых водоёмов в пределах Охотского и Берингова морей. За редким исключением у кеты в ходе нерестовых миграций преобладали рыбы в возрасте 3+ и 4+ [Макоедов и др., 2009], у нерки - 1.3+ и 2.3+ [Бугаев, 2011], кижуча - 1.1+ и 2.1+ [Зорбиди, 2010] и чавычи - 1.3+ и 1.4+ [Бугаев и др., 2007]. При этом у кеты и чавычи среди присутствующих на промысле возрастных классов, как правило, доминировали рыбы соответственно в возрасте 3+ и 1.3+, а особи возрастов 4+ и 1.4+ имели меньшую численность. У нерки и кижуча преобладали производители с двумя речными годами.

Установленные таким образом высокочисленные поколения тихоокеанских лососей (всего 97) также нанесены на кривые вылова (табл. 2, рис. 15). В данном случае обращает на себя внимание значительное увеличение числа урожайных поколений практически у всех видов лососей с начала 2000-х гг., что привело к существенному росту их уловов. Последнее стало возможным не только благодаря высокой численности производителей в этот период, но и благоприятным условиям их морского нагула [Шунтов, Темных, 2008]. Отметим, что отдельные поколения высокой численности могут проявлять себя в течение двух лет. Так, урожайные поколения кеты в возрасте 3+ доминируют в уловах во время нерестовых миграций, на следующий год рыбы того же года рождения обнаруживают себя в меньших количествах уже в возрасте 4+ (то же у чавычи в возрасте $1.3+$ и 1.4+). У нерки и кижуча высокочисленные поколения проявляются в первый год нереста в возрасте $1.3+$ и 1.1+ соответственно. На следующий год эти же поколения заходят в реки, но в отличие от кеты и чавычи, в большем количестве в возрасте 2.3+ у нерки и 2.1+ у кижуча. Характерный пример этого приведён для нерки западного побережья, когда урожайные поколения 2008, 2011 и 2014 гг. формировали повышенные уловы рыб соответственно в 2012-2013, 2015-2016 и 20182019 гг. (рис. 15 в).

Число поколений высокой численности, частота и периодичность их появления по отдельным запасам рыб приведены в табл. 3, данные которой показали наибольшее число урожайных генераций у восточноохотоморского минтая, восточнокамчатской трески, карагинских наваги и желтопёрой камбалы, охотской 
сельди, горбуши и горбуши северо-восточного побережья. Наименее плодовиты минтай северо-восточного Сахалина, западносахалинская треска, западнокамчатская навага, южный однопёрый терпуг, желтопёрая западносахалинская камбала, корфо-карагинская сельдь и чавыча западного побережья Камчатки. Максимальное число высокочисленных поколений рыб, следующих одно за другим ежегодно без перерывов, наблюдалось у желтопёрой камбалы залива Терпения (до 12 поколений), восточноохотоморского минтая, западносахалинской и карагинской желтопёрых камбал (до 6), анадырско-наваринской и западнокамчатской трески (до 5). Наиболее часто (через год и более) урожайные поколения появлялись у горбуши северо-восточного побережья, анадырско-наваринского минтая, восточнокамчатской трески, карагинских наваги

Таблица 2. Возраст формирования повышенной биомассы (вылова для лососёвых рыб) и годы появления урожайных поколений основных промысловых рыб в дальневосточных морях, тихоокеанских водах Камчатки и северных и южных Курильских островов

Table 2. The age of the formation of increased biomass (catch for salmon fish) and the years of the appearance of productive generations of the main commercial fish in the Far Eastern seas, Pacific waters of Kamchatka and the northern and southern Kuril Islands

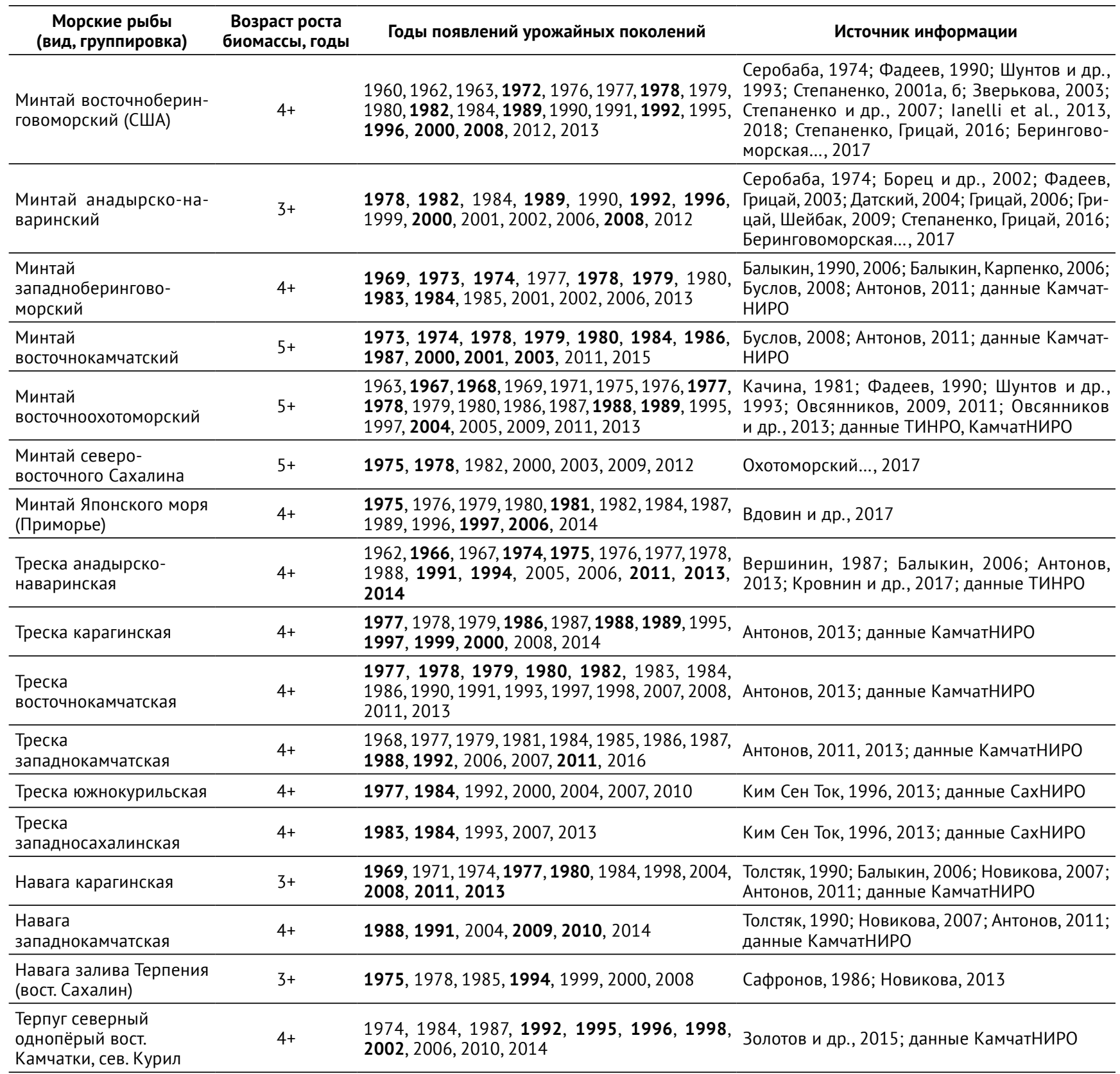




\section{А.В. ДАТСКИЙ, В.В. КУЛИК, С.А. ДАТСКАЯ}

ДИНАМИКА ОБИЛИЯ МАССОВЫХ ПРОМЫСЛОВЫХ РЫБ ДАЛЬНЕВОСТОЧНЫХ МОРЕЙ И ПРИЛЕГАЮЩИХ РАЙОНОВ ОТКРЫТОЙ ЧАСТИ ТИХОГО ОКЕАНА И ВЛИЯЮЩИЕ НА НЕЁ ФАКТОРЫ

Окончание табл. 2

\begin{tabular}{|c|c|c|c|}
\hline $\begin{array}{c}\text { Морские рыбы } \\
\text { (вид, группировка) }\end{array}$ & $\begin{array}{l}\text { Возраст роста } \\
\text { биомассы, годы }\end{array}$ & Годы появлений урожайных поколений & Источник информации \\
\hline $\begin{array}{l}\text { Терпуг южный } \\
\text { однопёрый южн. Курил }\end{array}$ & $3+$ & 1974, 1986, 1995, 1998, 2001, 2008, 2010, 2016 & Золотов, Фатыхов, 2016 \\
\hline $\begin{array}{l}\text { Камбала двухлинейная } \\
\text { восточнокамчатская }\end{array}$ & $5+(6+-8+)$ & $\begin{array}{l}\text { 1950, 1951,1952,1953,1972,1973,1976,1977, } \\
\text { 1978, 1981, 1982, 1983, 1988, 1989, 1990, } \\
1996,2004,2007,2008,2009\end{array}$ & Антонов, 2011; данные КамчатНИРО \\
\hline $\begin{array}{l}\text { Камбала желтопёрая } \\
\text { карагинская }\end{array}$ & $5+(6+-7+)$ & $\begin{array}{l}\text { 1952, 1953,1954, 1960, 1961, 1962, 1967, 1975, } \\
\text { 1976, 1977, 1978, 1979, 1980, 1984, 1986, 1987, } \\
1988,1992,1993,1997,1998,2004,2009,2010 \text {, } \\
2013\end{array}$ & Антонов, 2011; данные КамчатНИРО \\
\hline $\begin{array}{l}\text { Камбала желтопёрая } \\
\text { западнокамчатская }\end{array}$ & $5+(6+-8+)$ & $\begin{array}{l}\text { 1946, 1947, 1948, 1949, 1969, 1975, 1976, } \\
\text { 1977, 1978, 1982, 1984, 1986, 1990, 1993, 1994, } \\
1995,1998,1999,2004,2007,2010,2012\end{array}$ & $\begin{array}{l}\text { Антонов, 2011; Дьяков Ю.П., 2011; данные } \\
\text { КамчатНИРО }\end{array}$ \\
\hline $\begin{array}{l}\text { Камбала желтопёрая } \\
\text { залива Терпения (вост. } \\
\text { Сахалин) }\end{array}$ & $6+(6+-8+)$ & $\begin{array}{l}\text { 1946, 1947, 1950,1951, 1952, 1953, 1954, } \\
\text { 1955, 1956, 1957, 1958, 1959, 1960, 1961, } \\
\text { 1986, 1987, 1988, 1989, 1990, 1991, 2002, } \\
2003,2004\end{array}$ & $\begin{array}{l}\text { Тарасюк, 1997; Золотов и др., 2014; данные } \\
\text { СахНИРО }\end{array}$ \\
\hline $\begin{array}{l}\text { Камбала желтопёрая } \\
\text { западносахалинская }\end{array}$ & $5+(6+-8+)$ & $\begin{array}{l}\text { 1945, 1946, 1947, 1954, 1956, 1957, 1958, } \\
\text { 1959, 1960, 1961, 1979, 1981, 1982, 1983, } \\
\text { 1984, 1989,1990, } 2010\end{array}$ & $\begin{array}{l}\text { Тарасюк, 1997; Золотов и др., 2014; данные } \\
\text { СахНИРО }\end{array}$ \\
\hline $\begin{array}{l}\text { Сельдь } \\
\text { восточноберингово- } \\
\text { морская (РФ, США) } \\
\end{array}$ & $5+$ & $\begin{array}{l}\text { 1952, 1957, 1962, 1967, 1974, 1991, 2002, } \\
2003,2004,2005,2006,2007\end{array}$ & Науменко, 2001; Лобода, Жигалин, 2017 \\
\hline $\begin{array}{l}\text { Сельдь корфо- } \\
\text { карагинская }\end{array}$ & $5+$ & $\begin{array}{l}\text { 1923, 1944, 1951, 1952, 1956, 1971, 1993, } \\
2006,2009,2010\end{array}$ & $\begin{array}{l}\text { Науменко, 2001, 2010; Антонов, 2011; данные } \\
\text { КамчатНИРО }\end{array}$ \\
\hline $\begin{array}{l}\text { Сельдь гижигинско- } \\
\text { камчатская }\end{array}$ & $6+$ & $\begin{array}{l}\text { 1924, 1932, 1943, 1951, 1956, 1959, 1961, } \\
1971,1993,1994,2004,2005\end{array}$ & Науменко, 2001; Смирнов, 2006, 2014 \\
\hline Сельдь охотская & $6+$ & $\begin{array}{l}\text { 1925, 1931, 1933, 1952, 1957, 1958, 1962, } \\
\text { 1967, 1968, 1974, 1988, 1989, 1997, 2004, 2006, } \\
2007,2009,2014,2015\end{array}$ & $\begin{array}{l}\text { Науменко, 2001; Лобода, Мельников, 2005; Ло- } \\
\text { бода, 2007; Фархутдинов, 2005; данные Ма- } \\
\text { гаданНИРО }\end{array}$ \\
\hline $\begin{array}{l}\text { Горбуша северо- } \\
\text { восточного побережья }\end{array}$ & $1+$ & $\begin{array}{l}\text { 1988, 1990, 1992, 1994, 1996, 1998, 2002, 2006, } \\
2008,2010,2014,2015,2016,2017,2018\end{array}$ & Шунтов, Темных, 2011; собственные данные \\
\hline $\begin{array}{l}\text { Горбуша западного } \\
\text { побережья }\end{array}$ & $1+$ & $\begin{array}{l}\text { 1991, 1997, 1999, 2003, 2007, 2009, 2011, 2015, } \\
\text { 2017, } 2019\end{array}$ & $\begin{array}{l}\text { Радченко, 2009; Шунтов, 2016; собственные } \\
\text { данные }\end{array}$ \\
\hline $\begin{array}{l}\text { Кета северо-восточного } \\
\text { побережья }\end{array}$ & $3+, 4+$ & $\begin{array}{l}\text { 1976, 1980, 1983, 1987, 1997, 2002, 2004, 2006, } \\
2009,2011,2013,2016\end{array}$ & $\begin{array}{l}\text { Макоедов и др., 2009; Шунтов, Темных, 2011; } \\
\text { собственные данные }\end{array}$ \\
\hline $\begin{array}{l}\text { Кета западного } \\
\text { побережья }\end{array}$ & $3+, 4+$ & 1982, 1997, 1999, 2003, 2007, 2009, 2011, 2015 & Макоедов и др., 2009; собственные данные \\
\hline $\begin{array}{l}\text { Нерка северо- } \\
\text { восточного побережья }\end{array}$ & $1.3+, 2.3+$ & 1991, 1995, 2002, 2004, 2006, 2008, 2011, 2014 & Бугаев, 2011; собственные данные \\
\hline $\begin{array}{l}\text { Нерка западного } \\
\text { побережья }\end{array}$ & $1.3+, 2.3+$ & 1986, 1992, 1998, 2003, 2006, 2008, 2011, 2014 & Бугаев, 2011; собственные данные \\
\hline $\begin{array}{l}\text { Кижуч северо- } \\
\text { восточного побережья }\end{array}$ & $1.1+, 2.1+$ & $\begin{array}{l}\text { 1972, 1974, 1976, 1979, 1981, 1984, 1989, 2005, } \\
\text { 2011, 2012, } 2016\end{array}$ & Зорбиди, 2010; собственные данные \\
\hline $\begin{array}{l}\text { Кижуч западного } \\
\text { побережья }\end{array}$ & $1.1+, 2.1+$ & $1982,1989,2005,2008,2010,2012,2015,2017$ & Зорбиди, 2010; собственные данные \\
\hline $\begin{array}{l}\text { Чавыча северо- } \\
\text { восточного побережья }\end{array}$ & $1.3+, 1.4+$ & $\begin{array}{l}\text { 1968, 1971, 1973, 1979, 1982, 1989, 1995, 2002, } \\
2004,2006,2011\end{array}$ & Бугаев и др., 2007; собственные данные \\
\hline $\begin{array}{l}\text { Чавыча западного } \\
\text { побережья }\end{array}$ & $1.3+, 1.4+$ & 1971, 1978, 1982, 1987, 1992, 2004 & Бугаев и др., 2007; собственные данные \\
\hline
\end{tabular}

Примечание: Жирным шрифтом выделены возрастные группы, составляющие основу уловов лососей, а также суперурожайные поколения морских рыб.

и желтопёрой камбалы, северного однопёрого терпуга, охотской сельди.

В целом за весь период наблюдений именно генерации высокой численности, составившие около $20 \%$ всех проанализированных поколений, в большинстве своём и являлись основой для формирования высокой биомассы морских рыб в дальневосточных морях и прилегающих к ним акваториях. Безусловно, далеко 
ANDREY V. DATSKY, VLADIMIR V. KULIK, SOFIA A. DATSKAYA

THE DYNAMICS OF THE ABUNDANCE OF COMMERCIAL FISH IN THE FAR EASTERN SEAS AND ADJACENT AREAS OF THE OPEN PART OF THE PACIFIC OCEAN AND FACTORS INFLUENCING IT

Таблица 3. Число поколений высокой численности основных морских рыб, их частота и периодичность появления в дальневосточных морях, тихоокеанских водах Камчатки и северных и южных Курильских островов

Table 3. The number of generations of high numbers of the main marine fish, their frequency and frequency of occurrence in the Far Eastern seas, Pacific waters of Kamchatka and the northern and southern Kuril Islands

\begin{tabular}{|c|c|c|c|c|}
\hline Морские рыбы (виды, группировка) & $\begin{array}{l}\text { Число лет } \\
\text { наблюдений }\end{array}$ & $\begin{array}{l}\text { Число урож./ } \\
\text { суперурож. } \\
\text { поколений }\end{array}$ & $\begin{array}{c}\text { Частота появления } \\
\text { урож./суперурож. } \\
\text { поколений }\end{array}$ & $\begin{array}{l}\text { Периодичность появления урожайных } \\
\text { поколений (среднее, (пределы)) }\end{array}$ \\
\hline Минтай восточноохотоморский & 55 & $22 / 7$ & $2,5 / 7,9$ & 2 (1-6) поколения через 2,9 (1-6) года \\
\hline Минтай восточноберинговоморский (США) & 57 & $21 / 8$ & $2,7 / 7,1$ & $1,9(1-5)$ поколения через $3,3(1-8)$ года \\
\hline Минтай анадырско-наваринский & 39 & $14 / 7$ & $2,9 / 5,6$ & $1,4(1-4)$ поколения через 2,3 (1-4) года \\
\hline Минтай Японского моря (Приморье) & 43 & $13 / 4$ & $3,3 / 10,8$ & 1,6 (1-4) поколения через 3,9 (1-8) года \\
\hline Минтай восточнокамчатский & 44 & $13 / 11$ & $3,4 / 4,0$ & $1,6(1-3)$ поколения через 4,3 (1-12) года \\
\hline Минтай западноберинговоморский & 48 & $14 / 7$ & $3,4 / 6,9$ & 2 (1-4) поколения через 4,8 (2-15) года \\
\hline Минтай северо-восточного Сахалина & 43 & $7 / 2$ & $6,1 / 21,5$ & 1 поколение через 5,2 (2-17) года \\
\hline Треска восточнокамчатская & 41 & $17 / 5$ & $2,4 / 8,2$ & $1,9(1-4)$ поколения через $2,5(1-8)$ года \\
\hline Треска анадырско-наваринская & 55 & $16 / 8$ & $3,4 / 6,9$ & 1,8 (1-5) поколения через 4,6 (1-10) года \\
\hline Треска карагинская & 48 & $13 / 7$ & $3,7 / 6,9$ & 1,8 (1-4) поколения через 4,2 (1-7) года \\
\hline Треска западнокамчатская & 61 & $14 / 3$ & $4,4 / 20,3$ & 1,6 (1-5) поколения через 4,4 (1-13) года \\
\hline Треска южнокурильская & 41 & $7 / 2$ & $5,9 / 20,5$ & 1 поколение через 4,5 (2-18) года \\
\hline Треска западносахалинская & 35 & $5 / 2$ & $7,0 / 17,5$ & 1,3 (1-2) поколения через 8,7 (5-13) года \\
\hline Навага карагинская & 49 & $11 / 6$ & $4,5 / 8,2$ & 1 поколение через 3,4 (1-13) года \\
\hline Навага залива Терпения (вост. Сахалин) & 44 & $7 / 3$ & $6,3 / 14,7$ & 1,2 (1-2) поколения через 5,4 (2-8) года \\
\hline Навага западнокамчатская & 61 & $6 / 4$ & $10,2 / 15,3$ & $1,2(1-2)$ поколения через 5,3 (2-12) года \\
\hline $\begin{array}{l}\text { Терпуг северный однопёрый вост. Камчатки } \\
\text { и сев. Курил }\end{array}$ & 50 & $11 / 5$ & $4,5 / 10,0$ & 1,1 (1-2) поколения через 3,3 (1-9) года \\
\hline Терпуг южный однопёрый южных Курил & 44 & $8 / 3$ & $5,5 / 14,7$ & 1 поколение через 5 (1-11) лет \\
\hline Камбала желтопёрая карагинская & 67 & $25 / 8$ & $2,7 / 8,4$ & 2,3 (1-6) поколения через 3,7 (1-7) года \\
\hline $\begin{array}{l}\text { Камбала желтопёрая залива Терпения (вост. } \\
\text { Сахалин) }\end{array}$ & 72 & $23 / 13$ & $3,1 / 5,5$ & $5,8(2-12)$ поколения через $12(2-24)$ лет \\
\hline Камбала желтопёрая западнокамчатская & 71 & $22 / 9$ & $3,2 / 7,9$ & 1,7 (1-4) поколения через 3,8 (1-19) года \\
\hline Камбала двухлинейная восточнокамчатская & 67 & $20 / 8$ & $3,4 / 8,4$ & 2,5 (1-4) поколения через 5,7 (2-18) года \\
\hline Камбала желтопёрая западносахалинская & 73 & $18 / 9$ & $4,1 / 8,1$ & $2,6(1-6)$ поколения через $8(1-19)$ лет \\
\hline Сельдь охотская & 93 & $19 / 8$ & $4,9 / 11,6$ & 1,3 (1-2) поколения через 5,5 (1-18) года \\
\hline Сельдь восточноберинговоморская (РФ, США) & 66 & $12 / 5$ & $5,5 / 13,2$ & $1,7(1-6)$ поколения через 7,3 (4-16) года \\
\hline Сельдь гижигинско-камчатская & 94 & $12 / 4$ & $7,8 / 23,5$ & 1,2 (1-2) поколения через 7,8 (1-21) года \\
\hline Сельдь корфо-карагинская & 95 & $10 / 4$ & $9,5 / 23,8$ & 1,3 (1-2) поколения через 11,1 (2-21) года \\
\hline Горбуша северо-восточного побережья & 50 & $15 / 4$ & $3,3 / 12,5$ & $1,4(1-5)$ поколения через $1,6(1-3)$ года \\
\hline Кета северо-восточного побережья & 50 & $12 / 3$ & $4,2 / 16,7$ & 1 поколение через 2,6 (1-9) года \\
\hline Кижуч северо-восточного побережья & 50 & $11 / 4$ & $4,5 / 12,5$ & $1,1(1-2)$ поколения через 3,8 (1-15) года \\
\hline Чавыча северо-восточного побережья & 50 & $11 / 1$ & $4,5 / 50,0$ & 1 поколение через 3,3 (1-6) года \\
\hline Горбуша западного побережья & 50 & $10 / 3$ & $5,0 / 16,7$ & 1 поколение через 2,1 (1-5) года \\
\hline Кета западного побережья & 50 & $8 / 5$ & $6,3 / 10,0$ & 1 поколение через 3,7 (1-14) года \\
\hline Нерка западного побережья & 50 & $8 / 5$ & $6,3 / 10,0$ & 1 поколение через 3,0 (1-5) года \\
\hline Кижуч западного побережья & 50 & $8 / 4$ & $6,3 / 12,5$ & 1 поколение через 4,0 (1-15) года \\
\hline Нерка северо-восточного побережья & 50 & $8 / 2$ & $6,3 / 25,0$ & 1 поколение через 2,3 (1-6) года \\
\hline Чавыча западного побережья & 50 & $6 / 0$ & $8,3 /-$ & 1 поколение через 5,6 (3-11) года \\
\hline
\end{tabular}

Примечание. Рыбы даны (по видам, у тихоокеанских лососей в целом) в порядке увеличения частоты появлений поколений повышенной численности (урожайных, включая суперурожайные) за период наблюдений. Жирным шрифтом выделены лучшие показатели воспроизводительной способности (появление большего числа поколений высокой численности через меньшие промежутки времени) отдельных запасов морских рыб. 


\section{А.В. ДАТСКИЙ, В.В. КУЛИК, С.А. ДАТСКАЯ}

ДИНАМИКА ОБИЛИЯ МАССОВЫХ ПРОМЫСЛОВЫХ РЫБ ДАЛЬНЕВОСТОЧНЫХ МОРЕЙ И ПРИЛЕГАЮЩИХ РАЙОНОВ ОТКРЫТОЙ ЧАСТИ ТИХОГО ОКЕАНА И ВЛИЯЮЩИЕ НА НЕЁ ФАКТОРЫ

не всегда рост обилия рыб есть следствие влияния исключительно высокочисленных поколений (присутствует вклад, иногда значительный, рыб смежных генераций), однако воздействие урожайных поколений на увеличение биомассы и уловов рыб очевидно. Отметим при этом, что в отдельные годы неблагоприятные условия среды обитания гидробионтов вкупе с деятельностью человека могут приводить к нивелированию урожайных генераций, и ожидаемый рост обилия рыб не наблюдается.
Таким образом, в основном можно согласиться с тем, что наибольшие величины обилия морских рыб образованы особями поколений выше среднего. Принимая во внимание определяющее воздействие таких поколений на обилие рыб и их уловы, были выделены максимумы биомассы (вылова), приуроченные к конкретным годам (табл. 4, рис. 9-15). В большинстве случаев такие пики хорошо заметны, лишь у отдельных запасов рыб (минтай западноберинговоморский, восточнокамчатский и северо-восточного

Таблица 4. Максимумы биомассы (вылова) рыб и периодичность их формирования в дальневосточных морях, тихоокеанских водах Камчатки и северных и южных Курильских островов

Table 4. Maximum biomass (catch) of fish and the frequency of their formation in the Far Eastern seas, Pacific waters of Kamchatka and the northern and southern Kuril Islands

\begin{tabular}{|c|c|c|}
\hline Вид, группировка & Максимумы биомассы (вылова) рыб, годы & $\begin{array}{l}\text { Периодичность средняя } \\
\text { (пределы), лет }\end{array}$ \\
\hline Минтай Японского моря (Приморье) & 1980, 1991, 2000, 2010, 2019 & $9,8(9-11)$ \\
\hline Минтай анадырско-наваринский & $1986,1996,2005,2017$ & $10,3(9-12)$ \\
\hline Минтай восточнокамчатский & $1978,1991,2000,2009$ & $10,3(9-13)$ \\
\hline Минтай восточноберинговоморский (США) & $1971,1985,1993,2001,2014$ & $10,8(8-14)$ \\
\hline Минтай западноберинговоморский & $1979,1988, \underline{1997}, 2007,2020$ & $11,0(9-13)$ \\
\hline Минтай северо-восточного Сахалина & $1976,1986, \underline{1996}, 2008,2020$ & $11,0(10-12)$ \\
\hline Минтай восточноохотоморский & $1973,1985,1997,2010,2018$ & $11,2(8-13)$ \\
\hline Треска западносахалинская & $1989,1999,2013,2020$ & $10,3(7-14)$ \\
\hline Треска южнокурильская & $1988,1998,2011,2020$ & $10,6(9-13)$ \\
\hline Треска восточнокамчатская & 1986, 1996, 2009 & $11,5(10-13)$ \\
\hline Треска западнокамчатская & 1972, 1983, 1993, 2009, 2021 & $12,3(10-16)$ \\
\hline Треска анадырско-наваринская & $1969,1980,1996,2008,2018$ & $12,3(10-16)$ \\
\hline Треска карагинская & $1981,1992,2005,2019$ & $12,7(11-14)$ \\
\hline Навага залива Терпения (вост. Сахалин) & $1979,1987,1997,2010,2020$ & $10,3(8-13)$ \\
\hline Навага западнокамчатская & 1997, 2008, 2019 & $11,0(11)$ \\
\hline Навага карагинская & $1981,1989,2002,2015$ & $11,3(8-13)$ \\
\hline Терпуг южный одноперый южных Курил & $1977,1988,1997,2003,2013,2020$ & $8,6(6-11)$ \\
\hline $\begin{array}{l}\text { Терпуг северный одноперый вост. Камчатки и сев. Ку- } \\
\text { рил }\end{array}$ & $1971,1983,1993,2002,2008,2020$ & $9,8(6-12)$ \\
\hline Камбала желтопёрая западнокамчатская & $1952,1963,1974,1983,1991,2004,2019$ & $11,2(8-15)$ \\
\hline Камбала двухлинейная восточнокамчатская & $1957,1966,1978,1988,1998,2014$ & $11,4(9-16)$ \\
\hline Камбала желтопёрая залива Терпения (вост. Сахалин) & $1955,1965,1975,1985,1995,2012$ & $11,4(10-17)$ \\
\hline Камбала желтопёрая карагинская & $1955,1968,1984,1998,2005,2014$ & $11,8(7-16)$ \\
\hline Камбала желтопёрая западносахалинская & $1951,1964,1975,1988,1998,2012$ & $12,2(10-14)$ \\
\hline Сельдь восточноберинговоморская (США) & $1988,1993,2005,2008,2012,2018$ & $6,0(3-12)$ \\
\hline Сельдь охотская & $\begin{array}{l}\text { 1948, 1958, 1964, 1968, 1973, 1980, 1985, 1997, 2005, } \\
2010,2016\end{array}$ & $6,8(4-12)$ \\
\hline Сельдь гижигинско-камчатская & $\begin{array}{l}\text { 1948, 1957, 1962, 1967, 1978, 1983, 1990, 2001, } 2006, \\
2012,2017\end{array}$ & $6,9(5-11)$ \\
\hline Сельдь корфо-карагинская & $\begin{array}{l}\text { 1950, 1957, 1961, 1967, 1976, 1984, 1994, 1999, } 2008, \\
2015\end{array}$ & $7,2(4-10)$ \\
\hline Сельдь восточноберинговоморская (РФ) & 1965, 1973, 1982, 1992, 2001, 2010, 2015 & $8,3(5-10)$ \\
\hline Горбуша северо-восточного побережья & $\begin{array}{l}\text { 1971, 1973, 1975, 1977, 1979, 1981, 1989, 1991, 1993, } \\
\text { 1995, 1997, 1999, 2003, 2007, 2009, 2011, 2015, 2017, } \\
2019\end{array}$ & $2,7(2-8)$ \\
\hline Горбуша западного побережья & $\begin{array}{l}\text { 1979, 1983, 1996, 1998, 2000, 2002, 2004, 2008, } 2010 \text {, } \\
2012,2016,2018,2020\end{array}$ & $3,4(2-13)$ \\
\hline
\end{tabular}


Окончание табл. 4

\begin{tabular}{llc}
\hline \multicolumn{1}{c}{ Вид, группировка } & \multicolumn{1}{c}{ Максимумы биомассы (вылова) рыб, годы } & $\begin{array}{c}\text { Периодичность средняя } \\
\text { (пределы), лет }\end{array}$ \\
\hline Кижуч северо-восточного побережья & $\begin{array}{l}1974,1977,1979,1982,1984,1987,1992,1997,2002, \\
2008,2015,2018,2020\end{array}$ & $4,1(2-7)$ \\
\hline Нерка северо-восточного побережья & $1979,1984,1992,1996,1999,2007,2009,2013,2016$, & $4,4(2-8)$ \\
\hline Нерка западного побережья & 2019 & $4,8(2-6)$ \\
\hline Кижуч западного побережья & $1990,1996,2002,2007,2013,2015,2019$ & $5,0(2-11)$ \\
\hline Чавыча северо-восточного побережья & $1985,1992,1997,2000,2008,2010,2015,2018,2020$ & $5,3(2-9)$ \\
\hline Чавыча западного побережья & $1972,1975,1977,1983,1986,1993,1999,2008,2015$ & $5,4(3-11)$ \\
\hline Кета северо-восточного побережья & $1972,1975,1979,1982,1986,1992,1996,2008,2016$ & $5,7(3-10)$ \\
\hline Кета западного побережья & $1979,1983,1986,1990,2000,2009,2014,2019$ & \\
\hline
\end{tabular}

Примечание. Рыбы даны (по видам, у тихоокеанских лососей в целом) в порядке увеличения периодичности формирования обилия. В колонке «Максимумы биомассы (вылова) рыб, годы» подчёркнуты годы, в которые максимумы биомассы не наблюдались, однако такие пики были бы наиболее вероятны (объяснения в тексте). У горбуши приведены годы, когда её уловы были выше линии тренда.

Сахалина, желтопёрая камбала западных Камчатки и Сахалина, залива Терпения, сельдь восточноберинговоморская российских вод) в некоторые временные периоды максимумы биомасс не наблюдались. Однако с учётом определённой периодичности высоких биомасс для каждого из этих видов (популяций) подобные максимумы были бы с той или иной долей вероятности зафиксированы именно в конкретные годы (подчёркнуты в табл. 4). Основной причиной отсутствия высоких значений биомассы отмеченных выше группировок минтая в указанные годы следует признать воздействие чрезмерного и нерегулируемого промысла в 1980-1990-е гг. [Антонов, 2011]. То же можно сказать и в отношении желтопёрой камбалы, когда непомерный промысел среднетоннажных российских и японских судов у берегов западной Камчатки и Сахалина соответственно в 1950-х - первой половине 1970-х гг. и начале 1980-х гг. привёл к подрыву запасов вида [Фадеев, 1971; Борец, 1997; Тарасюк, 1997; Дьяков Ю.П., 2011]. Низкий уровень запасов региональных группировок вида в отмеченные периоды, по-видимому, и явился следствием того, что ожидаемые пики биомасс западнокамчатских, западно- и восточносахалинских камбал соответственно в 1963, 1975 и 1975 (1985) гг. не были сформированы (табл. 4). Снижение промыслового воздействия привело к постепенному восстановлению численности этих камбал (рис. 13 б-г) и появлению максимумов биомасс в последующие после провалов годы.

Для уточнения степени влияния промысла на обилие морских рыб (и возможного его исключения из перечня факторов, определяющих естественную динамику численности рыб) были рассчитаны доли их уловов от биомасс за весь период исследований. Аналогичная процедура расчётов проведена и для 2020 г., когда определили процентное соотношение общих допустимых уловов (ОДУ) или рекомендованного вылова (РВ) рыб от прогнозных оценок их биомасс, рассчитанных с использованием математических моделей в рамках предосторожного подхода [Бабаян, 2000].

Из данных табл. 5 можно сделать следующие выводы:

Во-первых, наибольший вылов от биомассы у анализируемых видов и группировок наблюдался в 1970-1990-е гг. (20 запасов из 28), в 2000-е гг. на большинство рыб промысловый пресс снизился.

Во-вторых, только два запаса (восточнокамчатский минтай и южнокурильская треска) максимально эксплуатировали на пике их биомасс, у прочих рыб высокая промысловая нагрузка отмечалась до или после максимумов обилия.

В третьих, если сравнивать долю прогнозируемого вылова от обилия в 2020 г. с аналогичными показателями 2010-2019 гг., когда расчётные показатели биомасс рыб были методически приближены к оптимальным с точки зрения минимизации ущерба от проведения промысла, можно заметить, что она практически по всем запасам имеет тенденцию к увеличению. Только у шести группировок (западноберинговоморский минтай, минтай северо-восточного Сахалина, анадырско-наваринская треска, навага залива Терпения, восточнокамчатская двухлинейная и западнокамчатская желтопёрая камбалы) доля прогнозируемого вылова от биомассы рекомендована к снижению. При этом для трески северо-западной части Берингова моря такая рекомендация обусловлена резким ростом биомассы рыб вследствие появления нескольких урожайных поколений [Кровнин и др., 2017] и повышением миграционной активности рыб из восточной части моря в западную. Ежегодный ОДУ данной группировки был увеличен с 29,5 тыс. Т 


\section{А.В. ДАТСКИЙ, В.В. КУЛИК, С.А. ДАТСКАЯ}

ДИНАМИКА ОБИЛИЯ МАССОВЫХ ПРОМЫСЛОВЫХ РЫБ ДАЛЬНЕВОСТОЧНЫХ МОРЕЙ И ПРИЛЕГАЮЩИХ РАЙОНОВ ОТКРЫТОЙ ЧАСТИ ТИХОГО ОКЕАНА И ВЛИЯЮЩИЕ НА НЁ̈ ФАКТОРЫ

Таблица 5. Доля вылова морских рыб от их биомассы (\%) в дальневосточных морях и прилегающих акваториях в 1940-2020 гг.

Table 5. The share of marine fish catch from their biomass (\%) in the Far Eastern seas and adjacent waters in 1940-2020.

\begin{tabular}{|c|c|c|c|c|c|c|c|c|c|c|}
\hline Вид, группировка & 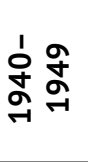 & $\begin{array}{l}1 \\
\text { 오ํ } \\
\text { ผू } \\
\text { ने }\end{array}$ & 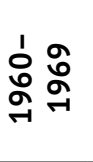 & $\begin{array}{l}1 \\
\stackrel{1}{N} \\
\text { a } \\
\text { न }\end{array}$ & $\begin{array}{l}1 \\
\text { o } \\
\infty \\
\text { a } \\
\sigma \\
\text { ने }\end{array}$ & $\begin{array}{l}\text { ’ g } \\
\text { ब } \\
\text { g }\end{array}$ & 응 용 & l' & $\begin{array}{c}\text { Доля вылова от } \\
\text { биомассы } \\
\text { (средняя, } \\
\text { (пределы)), \% }\end{array}$ & $\begin{array}{c}\text { ОДУ/РВ } \\
\text { в } 2020 \text { г. } \\
\text { от био- } \\
\text { массы, \% }\end{array}$ \\
\hline $\begin{array}{l}\text { Минтай северо-восточного } \\
\text { Сахалина }\end{array}$ & - & - & - & 7,7 & 10,2 & 10,0 & 3,1 & 22,5 & $11,1(1,0-35,0)$ & 22,4 \\
\hline Минтай анадырско-наваринский & - & - & - & 17,3 & 42,9 & 40,7 & 28,6 & 11,2 & $30,5(9,3-77,4)$ & 13,7 \\
\hline Минтай восточнокамчатский & - & - & - & 44,5 & 27,5 & 18,6 & 9,5 & 11,4 & $19,8(4,4-53,2)$ & 13,4 \\
\hline Минтай восточноохотоморский & - & - & 8,4 & 16,6 & 12,5 & 18,6 & 10,4 & 9,5 & $12,9(0,9-25,2)$ & 10,8 \\
\hline $\begin{array}{l}\text { Минтай восточноберинговоморский } \\
\text { (США) }\end{array}$ & - & - & 7,0 & 11,7 & 6,4 & 7,9 & 10,0 & 7,2 & $8,5(3,5-23,4)$ & 9,4 \\
\hline Минтай Японского моря (Приморье) & - & - & - & 25,0 & 18,4 & 7,9 & 3,2 & 2,9 & $9,6(0,1-41,3)$ & 9,3 \\
\hline Минтай западноберинговоморский & - & - & - & 11,7 & 12,9 & 26,6 & 22,9 & 13,7 & $17,6(2,1-77,1)$ & 3,8 \\
\hline Треска карагинская & - & - & - & 2,1 & 7,9 & 11,0 & 11,7 & 25,5 & $11,8(0-34,0)$ & 34,9 \\
\hline Треска западнокамчатская & - & 4,8 & 8,5 & 6,7 & 11,4 & 5,9 & 9,5 & 11,3 & $8,7(2,2-25,0)$ & 31,9 \\
\hline Треска западносахалинская & - & - & - & - & - & - & 4,1 & 4,1 & $4,4(1,7-9,8)$ & 23,2 \\
\hline Треска восточнокамчатская & - & - & - & 6,5 & 17,1 & 23,6 & 14,7 & 18,5 & $17,6(3,7-35,7)$ & 21,3 \\
\hline Треска южнокурильская & - & - & - & - & 16,3 & 10,4 & 4,7 & 10,5 & $10,3(0,1-34,1)$ & 20,4 \\
\hline Треска анадырско-наваринская & - & - & 11,5 & 37,1 & 16,4 & 12,2 & 10,4 & 6,7 & $16,4(0,1-118,8)$ & 3,7 \\
\hline Навага карагинская & - & - & - & 9,1 & 9,9 & 12,8 & 10,7 & 5,6 & $9,6(1,1-33,2)$ & 26,5 \\
\hline Навага западнокамчатская & - & 32,5 & 39,6 & 28,9 & 6,6 & 13,2 & 17,3 & 13,2 & $20,4(0,1-71,4)$ & 25,2 \\
\hline $\begin{array}{l}\text { Навага залива Терпения (вост. } \\
\text { Сахалин) }\end{array}$ & - & - & - & - & 20,2 & 21,1 & 29,7 & 29,6 & $26,4(8,3-41,7)$ & 22,2 \\
\hline $\begin{array}{l}\text { Терпуг северный однопёрый вост. } \\
\text { Камчатки и сев. Курил }\end{array}$ & - & - & 16,3 & 18,3 & 3,2 & 3,4 & 9,6 & 15,9 & $10,3(0,3-47,0)$ & 17,3 \\
\hline $\begin{array}{l}\text { Терпуг южный однопёрый южных } \\
\text { Курил }\end{array}$ & - & - & - & 4,6 & 17,6 & 6,5 & 5,9 & 4,7 & $8,4(0,3-35,1)$ & 15,8 \\
\hline Камбала желтопёрая карагинская & - & 17,6 & 12,1 & 15,7 & 14,2 & 11,1 & 18,5 & 16,3 & $14,9(0,7-42,0)$ & 20,3 \\
\hline $\begin{array}{l}\text { Камбала желтоперая } \\
\text { западнокамчатская }\end{array}$ & - & 7,3 & 16,6 & 13,1 & 6,0 & 3,6 & 17,5 & 22,3 & $12,3(1,2-34,6)$ & 17,8 \\
\hline $\begin{array}{l}\text { Камбала желтопёрая залива } \\
\text { Терпения (вост. Сахалин) }\end{array}$ & - & 12,8 & 13,5 & 17,0 & 1,1 & 5,9 & 11,6 & 5,9 & $9,7(0-31,3)$ & 11,5 \\
\hline $\begin{array}{l}\text { Камбала желтопёрая } \\
\text { западносахалинская }\end{array}$ & - & 6,5 & 4,5 & 5,1 & 4,2 & 4,2 & 7,2 & 4,3 & $5,2(0,9-14,1)$ & 17,3 \\
\hline $\begin{array}{l}\text { Камбала двухлинейная } \\
\text { восточнокамчатская }\end{array}$ & - & 14,4 & 19,3 & 12,5 & 12,5 & 11,3 & 12,7 & 14,3 & $13,8(4,3-26,4)$ & 10,7 \\
\hline Сельдь охотская & 2,6 & 8,8 & 20,2 & 25,9 & 14,5 & 24,2 & 23,0 & 17,4 & $18,3(2,4-54,1)$ & 23,4 \\
\hline Сельдь гижигинско-камчатская & 5,2 & 8,9 & 11,4 & 18,9 & 1,9 & 3,3 & 6,4 & 17,4 & $9,5(0,2-59,6)$ & 20,5 \\
\hline Сельдь корфо-карагинская & 1,0 & 2,5 & 24,3 & 2,0 & 8,3 & 6,8 & 5,2 & 11,1 & $7,6(0-54,3)$ & 17,8 \\
\hline $\begin{array}{l}\text { Сельдь восточноберинговоморская } \\
\text { (РФ) }\end{array}$ & - & 5,1 & 8,3 & 13,1 & 7,3 & 188,0 & 122,6 & 8,1 & $48,6(1,3-789,4)$ & 12,1 \\
\hline $\begin{array}{l}\text { Сельдь восточноберинговоморская } \\
\text { (США) }\end{array}$ & - & - & - & - & - & - & 12,7 & 9,5 & $11,5(7,4-16,0)$ & - \\
\hline
\end{tabular}

Примечание. Жирным шрифтом выделены наибольшая доля (\%) вылова рыб относительно их биомассы, а также популяции рыб, доля вылова которых ниже в прогнозе на 2020 г. относительно периода 2010-2019 гг. Серым цветом выделены периоды наибольшей биомассы видов и популяций рыб (см. рис. 9-14). 
в 2016 г. до 120,0 тыс. т в 2020 г., а дальнейший рост уловов трески, несмотря на имеющиеся возможности, оказался нецелесообразен по причине неготовности флота к освоению большего объёма ресурса.

В целом на современном этапе основные виды рыб в северо-западной части Тихого океана осваиваются в щадящем режиме, их вылов с 2009 г. поступательно растёт [Антонов, Датский, 2019], не оказывая значительного воздействия на биомассу (рис. 9-15). Лишь в редких случаях в условиях значительного перелова можно предположить, что рыбопромысловая деятельность приводит к изменению обилия рыб и её периодичности. Именно такая ситуация наблюдалась в 1990-е гг. в отношении западноберинговоморской и восточнокамчатской группировок минтая, восточноберинговоморской сельди в водах России, когда прогнозируемые пики их биомасс соответственно в 1997, 2000 и 1992 гг. не были сформированы по причине сравнительно высокой доли их изъятия относительно биомассы рыб. Здесь же можно привести и указанные выше примеры с западнокамчатской и восточносахалинской желтопёрыми камбалами, когда после пика их биомасс уровень промыслового изъятия, вместо ожидаемого снижения, существенно возрастал (табл. 4, 5).

Сообразно выделенным максимумам биомассы и вылова для конкретных запасов рыб, рассчитана периодичность формирования обилия, которая для каждого вида или группировки изменялась от минимальных значений у лососей до наибольших величин у трески и камбал (табл. 4). У минтая периоды появления наибольшей биомассы находились в пределах 9,9-11,2 лет; трески - 10,3-12,7; наваги - 10,3-11,3; терпугов - 8,6-9,8; желтопёрой камбалы - 11,2-12,2; сельди - 6,0-8,3 лет. У лососёвых, за исключением горбуши, цикличность появления повышенных уловов была наименьшей у нерки (4,4-4,8 лет) и кижуча $(4,1-5,0)$, далее следовала чавыча $(5,3-5,4)$, а наибольший период между высокими уловами наблюдался у кеты - 5,7-6,8.

Периодичность в формировании повышенной биомассы или вылова у региональных группировок рыб различалась (табл. 4, 6). У минтая наибольшие интервалы между максимумами обилия наблюдались у рыб Охотского моря и южной части Берингова моря, наименьшие - у особей северо-западной части Берингова моря, тихоокеанских вод Камчатки и акватории Японского моря (Приморье). У трески длительные по времени пики биомасс, помимо рыб с западной Камчатки, выявлены у группировок, обитающих в западной части Берингова моря и тихоокеанских водах Камчатки. Наименьшая цикличность присуща рыбам южных Курил и западного Сахалина. У наваги, желтопёрой камбалы и сельди ситуация обратная:

Таблица 6. Группировки морских рыб с наибольшей и наименьшей периодичностью формирования повышенной биомассы (вылова)

Table 6. Groupings of marine fish with the highest and lowest frequency of formation of increased biomass (catch)

\begin{tabular}{|c|c|c|}
\hline Вид & Группировки с наибольшей периодичностью & Группировки с наименьшей периодичностью \\
\hline Минтай & $\begin{array}{l}\text { Охотское море (восточноохотоморская, северо-вос- } \\
\text { точного Сахалина), } \\
\text { юго-восточная и юго-западная части Берингова } \\
\text { моря (восточноберинговоморская, западноберин- } \\
\text { говоморская) }\end{array}$ & $\begin{array}{l}\text { Северо-западная часть Берингова моря } \\
\text { (анадырско-наваринская), тихоокеанские } \\
\text { воды Камчатки (восточнокамчатская), } \\
\text { Японское море (Приморье) }\end{array}$ \\
\hline Треска & $\begin{array}{l}\text { Охотское море (западнокамчатская), } \\
\text { западная часть Берингова моря (анадырско-нава- } \\
\text { ринская, карагинская), } \\
\text { тихоокеанские воды Камчатки (восточнокамчат- } \\
\text { ская) }\end{array}$ & $\begin{array}{l}\text { Тихоокеанские воды южных Курил (южно- } \\
\text { курильская), } \\
\text { Японское море (западносахалинская) }\end{array}$ \\
\hline Навага & $\begin{array}{l}\text { Охотское море (западнокамчатская), } \\
\text { юго-западная часть Берингова моря (карагинская) }\end{array}$ & Охотское море (восточный Сахалин) \\
\hline Желтоперая камбала & $\begin{array}{l}\text { Юго-западная часть Берингова моря (карагинская), } \\
\text { Японское море (западносахалинская) }\end{array}$ & $\begin{array}{l}\text { Охотское море (западнокамчатская, вос- } \\
\text { точный Сахалин) }\end{array}$ \\
\hline Сельдь & $\begin{array}{l}\text { Западная часть Берингова моря (восточноберинго- } \\
\text { воморская, корфо-карагинская) }\end{array}$ & $\begin{array}{l}\text { Юго-восточная часть Берингова моря (вос- } \\
\text { точноберинговоморская), Охотское море } \\
\text { (охотская, гижигинско-камчатская) }\end{array}$ \\
\hline Тихоокеанские лососи & Кета и чавыча обоих побережий & $\begin{array}{l}\text { Горбуша обоих побережий, } \\
\text { кижуч и нерка северо-восточного побе- } \\
\text { режья }\end{array}$ \\
\hline
\end{tabular}


за исключением западнокамчатской наваги большие промежутки в формировании биомасс рыб выявлены в российских водах Берингова моря, а меньшие в акватории Охотского моря.

Вышесказанное вероятно может быть объяснено особенностями формирования абиотического фона дальневосточных морей и прилегающих тихоокеанских вод, имеющего специфические региональные особенности и значимые различия. Воздействие природных факторов в северных и южных акваториях северо-западной части Тихого океана зачастую находится в противофазе [Шунтов, Темных, 2008; 2011; Шунтов, 2001; 2016]. При этом существенные различия в условиях среды наблюдаются и в пределах одного водоёма и не только в направлении от севера к югу: западные части Охотского и Берингова морей суровее восточных [Шунтов, Иванов, 2019].

Если рассматривать периодичность формирования обилия по видам в целом, то наибольшая цикличность наблюдалась у типично донно-придон- ных желтопёрой камбалы и трески: соответственно 11,7 и 11,6 лет. Меньшую цикличность имели навага (10,9 лет), преимущественно донный вид, и минтай (10,6 лет), в полной мере осваивающий как пелагиаль, так и акваторию у дна.

Далее в порядке убывания находились обитающие во взрослом состоянии у дна северный и южный однопёрые терпуги (9,8 и 8,6 лет соответственно), пелагические сельдь $(7,1)$ и тихоокеанские лососи $(4,8)$. Сходные результаты в периодических колебаниях численности отдельных рыб в бассейнах Каспийского и Аральского морей, пелагиали Охотского моря и отдельных реках Дальнего Востока были отмечены и ранее [Кулик, 2007; 2009; Никольский, 2012].

Говоря о колебаниях численности, следует понимать, что у всех проанализированных рыб биология и экология различны (табл. 7, 8). В первую очередь, надо отметить, что сроки нереста у рассматриваемых видов разные: у минтая, трески, наваги, сельди нерест зимне-весенний и протекает в неблагоприятный пе-

Таблица 7. Сроки нереста и особенности распределения нерестующих особей, икры и личинок основных морских рыб в дальневосточных морях, тихоокеанских водах Камчатки и северных и южных Курильских островов

Table 7. Spawning periods and distribution patterns of spawning individuals, eggs and larvae of the main marine fish in the Far Eastern seas, Pacific waters of Kamchatka and the northern and southern Kuril Islands

\begin{tabular}{|c|c|c|c|c|}
\hline Вид, группировка & $\begin{array}{l}\text { Сроки нереста } \\
\text { (пик), месяцы }\end{array}$ & $\begin{array}{l}\text { Распределение не- } \\
\text { рестующих рыб }\end{array}$ & $\begin{array}{c}\text { Распределение икры } \\
\text { (личинок) }\end{array}$ & Источник \\
\hline $\begin{array}{l}\text { Минтай восточноберингово- } \\
\text { морский (США) }\end{array}$ & $2-6(4-5)$ & $\begin{array}{c}\text { над } 1500-3000 \text { м } \\
\text { (в слое } 300-500 \text { м), } \\
50-180 \text { м (у дна) }\end{array}$ & $\begin{array}{c}\text { Поверхностный слой } \\
0-60 \mathrm{M} \\
(0-400 \mathrm{M})\end{array}$ & $\begin{array}{l}\text { Серобаба, 1968; 1974; Okada, 1986; } \\
\text { Булатов, 1987; 2004; 2017; Hinckley, } \\
\text { 1987; Stepanenko, 1989; Шунтов } \\
\text { и др., } 1993\end{array}$ \\
\hline $\begin{array}{l}\text { Минтай анадырско- } \\
\text { наваринский }\end{array}$ & $4-9(5-6)$ & $\begin{array}{l}240-380 \text { м (у дна), } \\
40-90 \text { м (у дна) }\end{array}$ & $\begin{array}{c}\text { Поверхностный слой } \\
0-60 \mathrm{M} \\
(0-500 \mathrm{M})\end{array}$ & $\begin{array}{l}\text { Качина, Балыкин, 1981; Фадеев, } \\
\text { 1981; 1988; Булатов, 1986; 1987; } \\
\text { 2004; Шунтов и др., 1993; Балыкин, } \\
\text { Варкентин, 2002; Датский, } 2004\end{array}$ \\
\hline $\begin{array}{l}\text { Минтай } \\
\text { западноберинговоморский }\end{array}$ & $3-6(5)$ & 150-500 м (у дна) & $\begin{array}{c}\text { Поверхностный слой } \\
0-60 \mathrm{M} \\
(0-200 \mathrm{M})\end{array}$ & $\begin{array}{l}\text { Качина, Балыкин, 1981; Булатов, } \\
\text { 1986; Балыкин, 1993; Шунтов и др., } \\
1993\end{array}$ \\
\hline Минтай восточнокамчатский & $3-6(4-5)$ & $\begin{array}{c}\text { над } 800-1500 \text { м } \\
\text { (в слое 200-600 м), } \\
50-150 \text { м (у дна) }\end{array}$ & $\begin{array}{c}\text { Поверхностный слой } \\
0-60 \mathrm{M} \\
(0-600 \mathrm{M})\end{array}$ & $\begin{array}{l}\text { Антонов, Золотов, 1987; Антонов, } \\
\text { 1991; Буслов, 2001; Буслов, Тепнин, } \\
2002 ; \text { Буслов и др., 2004; Булатов, } \\
2017\end{array}$ \\
\hline $\begin{array}{l}\text { Минтай } \\
\text { восточноохотоморский }\end{array}$ & $1-6(4)$ & 50-200 м (у дна) & $\begin{array}{c}\text { Поверхностный слой } \\
0-60 \text { м }\end{array}$ & $\begin{array}{l}\text { Горбунова, 1954; Зверькова, 1969; } \\
\text { 1987; Пушников, 1980; 1982; Фаде- } \\
\text { ев, 1981; 1987; Вышегородцев, 1987; } \\
\text { Золотов, 1991; Шунтов и др., 1993; } \\
\text { Овсянников, 2011; Варкентин, } 2015\end{array}$ \\
\hline $\begin{array}{l}\text { Минтай северо-восточного } \\
\text { Сахалина }\end{array}$ & $3-6(4-5)$ & 50-150 м (у дна) & $\begin{array}{c}\text { Поверхностный слой } \\
\text { 0-60 м }\end{array}$ & $\begin{array}{l}\text { Пушников, 1978; 1982; Зверькова, } \\
\text { Пушников, 1980; Зверькова, 1981; } \\
\text { Фадеев, Смирнов, 1987; Шунтов } \\
\text { и др., } 1993\end{array}$ \\
\hline $\begin{array}{l}\text { Минтай Японского моря } \\
\text { (Приморье) }\end{array}$ & $1-5(4)$ & 50-200 м (у дна) & $\begin{array}{c}\text { Поверхностный слой } \\
\text { 0-60 м }\end{array}$ & $\begin{array}{l}\text { Горбунова, 1954; Зверькова, 1971; } \\
\text { 1977; Нуждин, 1987; 2008; Шунтов } \\
\text { и др., 1993; Фадеев, } 2009\end{array}$ \\
\hline $\begin{array}{l}\text { Треска анадырско- } \\
\text { наваринская }\end{array}$ & $3-5(4)$ & 130-370 м (у дна) & 75-250 м, у дна & $\begin{array}{l}\text { Моисеев, 1953; Мухачева, Звягина, } \\
\text { 1960; Антонов, } 2013\end{array}$ \\
\hline Треска карагинская & $2-4(3)$ & 120-270 м (у дна) & 120-250 м, у дна & $\begin{array}{l}\text { Моисеев, 1953; Vinnikov, 1996; Анто- } \\
\text { нов, 2013; Савин, } 2013\end{array}$ \\
\hline
\end{tabular}


ANDREY V. DATSKY, VLADIMIR V. KULIK, SOFIA A. DATSKAYA

THE DYNAMICS OF THE ABUNDANCE OF COMMERCIAL FISH IN THE FAR EASTERN SEAS AND ADJACENT AREAS OF THE OPEN PART OF THE PACIFIC OCEAN AND FACTORS INFLUENCING IT

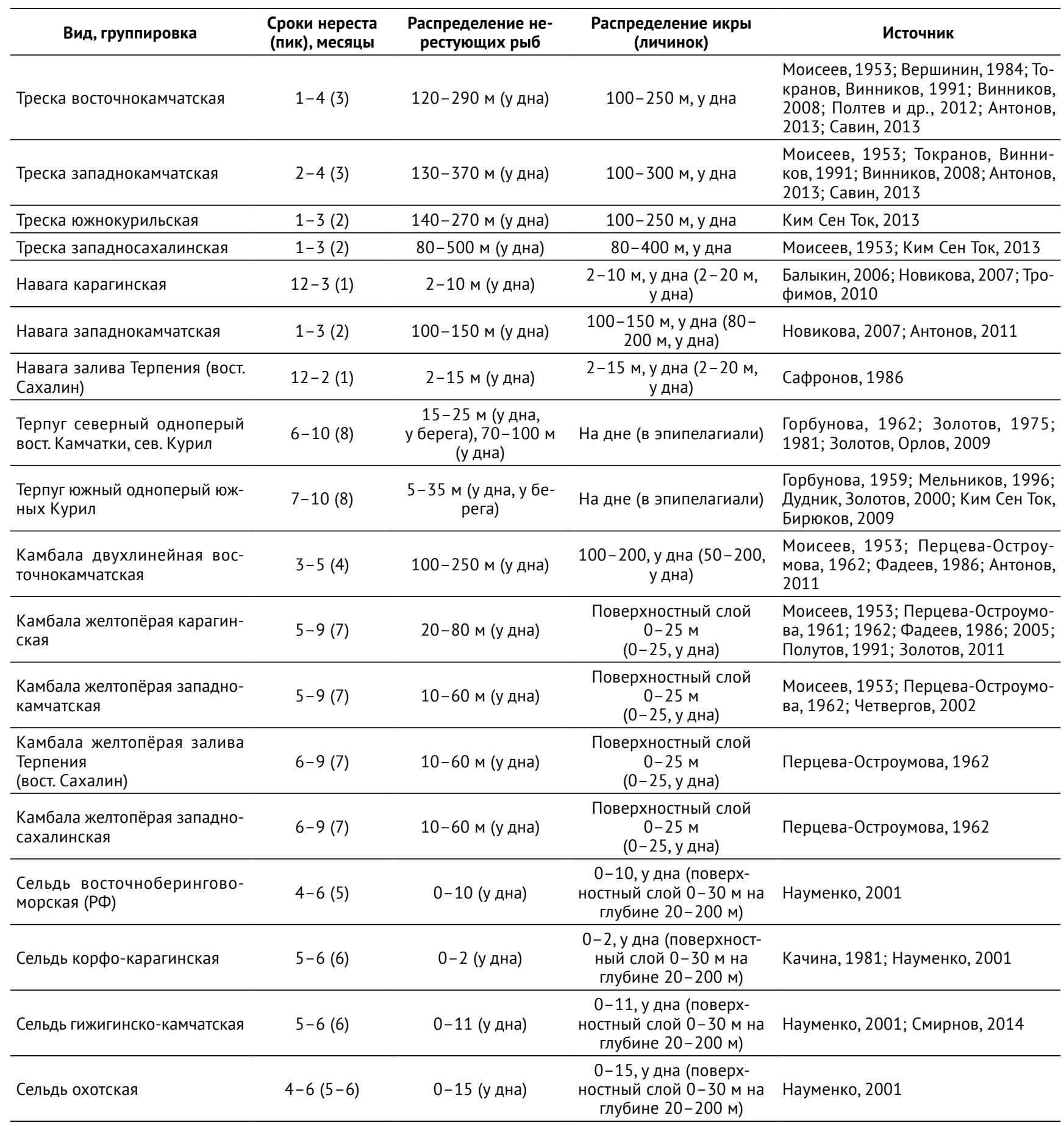

риод времени (тяжёлая ледовая обстановка, относительно низкие температурные показатели, сложные гидрометеоусловия), у терпугов и желтопёрой камбалы - преимущественно летне-осенний, когда условия среды более благоприятные. Во-вторых, нерестилища у терпугов, карагинской и восточносахалинской наваги, сельди находятся в прибрежных водах, зачастую в приливно-отливной зоне, где фоновые усло- вия довольно лабильны, у прочих видов, за исключением лососей, места нереста располагаются на значительных глубинах, как правило, у дна с более стабильной абиотикой. Тихоокеанские лососи в данном случае имеют наиболее экстремальные условия для нереста, когда, помимо перехода из солёной водной среды в пресную, они вынуждены преодолевать значительные расстояния и препятствия в пределах не- 
рестовых рек. В третьих, общее выживание рыб и их естественная смертность во многом обусловлены особенностями распределения икры и личинок и средой, в которой они развиваются. И здесь лососи также находятся в невыгодных условиях: личинки вылупляются зимой-весной, и в период ската численность молоди в значительной степени регулируется температурой воды и ледовитостью, влияющих на развитие кормовой базы, в результате в холодные годы могут появиться высокоурожайные поколения и наоборот [Шунтов, Темных, 2011]. У прочих видов условия развития икры и личинок более стабильны, не считая сельдь, навагу (без западнокамчатской группировки) и желтопёрую камбалу, у которых численность будущих поколений закладывается в прибрежье, где гидрологический и температурный режимы менее устойчивы, нежели на больших глубинах.

Таким образом, особенности биологии и экологии рыб формируют специфические для каждого вида или популяции реакции на воздействие внешних факторов среды, оказывающих к тому же влияние в пределах ограниченных морских акваторий. Здесь необходимо учитывать и различные природные стратегии размножения живых организмов, при определённых обстоятельствах обеспечивающие оптимальную численность для конкретных видов. Среди разнообразных экологических стратегий, свойственных тем или иным видам и направленным в конечном итоге на повышение вероятности выживания, выделяются $r$-стратегия, определяемая отбором, направленным на повышение скорости роста воспроизводства, и К-стратегия, связанная с отбором на повышение выживаемости [Mac-Arthur, Wilson, 1967]. В нашем случае к представителям последней можно отнести камбал, имеющих более стабильное развитие в силу большей продолжительности жизни и относительно высокой адаптаций к воздействию климата, к первым - всех остальных. Для камбал характерно появление двух и более (до 12, табл. 3) смежных поколений высокой численности, которые разделены значительными временными периодами. У прочих запасов рыб, как правило, одно (реже два) урожайное поколение появляется через меньшее число лет (минимально у минтая, терпугов, наваги и лососей). Отметим, что у сельди, как и у камбал, выявлены сходные значительные временные периоды между появлением высокочисленных поколений, с той лишь разницей, что у сельди единовременно появлялось в основном одно поколение. Можно предположить, что влияние факторов среды на обилие камбал менее чувствительно по причине компенсации численности рыбами смежных поколений: сглаженные максимумы биомассы формируются с большей амплитудой.

Таблица 8. Сроки нереста производителей, выклева личинок и ската молоди тихоокеанских лососей западного и северо-восточного побережья Камчатки и Чукотки

Table 8. Terms of spawning of producers, hatching of larvae and stingrays of juvenile Pacific salmon on the western and northeastern coast of Kamchatka and Chukotka

\begin{tabular}{|c|c|c|c|c|}
\hline Вид, расположение & $\begin{array}{l}\text { Сроки нереста } \\
\text { (пик), месяцы }\end{array}$ & $\begin{array}{l}\text { Сроки выкле- } \\
\text { ва личинок, } \\
\text { месяцы }\end{array}$ & $\begin{array}{l}\text { Скат молоди (пре- } \\
\text { обладающий воз- } \\
\text { раст, годы), месяцы }\end{array}$ & Источник информации \\
\hline $\begin{array}{l}\text { Горбуша северо-восточного } \\
\text { побережья }\end{array}$ & $7-11(8)$ & $9-2$ & $5-8(0+)$ & Шунтов, Темных, 2008 \\
\hline Горбуша западного побережья & $7-11(8)$ & $9-2$ & $4-7(0+)$ & Шунтов, Темных, 2008 \\
\hline $\begin{array}{l}\text { Кета северо-восточного } \\
\text { побережья }\end{array}$ & $7-11(8)$ & $1-3$ & $5-8(0+)$ & $\begin{array}{l}\text { Шунтов, Темных, 2008; Макоедов и др., } \\
2009\end{array}$ \\
\hline Кета западного побережья & $7-11(8)$ & $1-3$ & $4-7(0+)$ & $\begin{array}{l}\text { Шунтов, Темных, 2008; Макоедов и др., } \\
2009\end{array}$ \\
\hline $\begin{array}{l}\text { Нерка северо-восточного } \\
\text { побережья }\end{array}$ & $6-12(7-8)$ & $1-5$ & $3-9(1+, 2+)$ & Шунтов, Темных, 2008; Бугаев, 2011 \\
\hline Нерка западного побережья & $6-12(7-8)$ & $1-5$ & $5-7(1+, 2+)$ & Шунтов, Темных, 2008; Бугаев, 2011 \\
\hline $\begin{array}{l}\text { Кижуч северо-восточного } \\
\text { побережья }\end{array}$ & $6-10(8-9)$ & $1-8$ & $5-8(1+, 2+)$ & Шунтов, Темных, 2008; Зорбиди, 2010 \\
\hline Кижуч западного побережья & $7-2(8-9)$ & $1-8$ & $5-8(1+, 2+)$ & Шунтов, Темных, 2008; Зорбиди, 2010 \\
\hline $\begin{array}{l}\text { Чавыча северо-восточного } \\
\text { побережья }\end{array}$ & $8-9$ & $10-5$ & $5-8(1+)$ & Шунтов, Темных, 2008 \\
\hline Чавыча западного побережья & $6-9(7-8)$ & $10-5$ & $4-8(1+)$ & Шунтов, Темных, 2008 \\
\hline
\end{tabular}


Для выявления воздействия абиотических и прочих факторов на обилие морских рыб на основе многолетних данных межгодовой изменчивости факторов среды, упомянутых в разделе «Материал и методика» [Datsky et al., 2021: табл. 1], была рассчитана сила связи между ними и биомассой рыб, которая измерялась через МИК. Первичный анализ МИК показал, что без сдвига находятся 8750 статистических связей, где МИК $\geqslant 0,9$, а со сдвигом - 42773 [Datsky et al., 2021: табл. 2, 3]. Объяснение полученных результатов может быть представлено в дальнейших исследованиях. Здесь отметим, что среди используемых в работе факторов среды (табл. 9), тесно связанных с обилием региональных группировок морских рыб, наиболее часто встречающимися являются температура воды в различных горизонтах (от поверхности до дна), ледовитость, цветение фитопланктона и биомасса различных фракций и видов зоопланктона.

Таблица 9. Значимые связи (значения МИК $\geqslant 0,9$ ) между факторами среды и биомассой рыб в морских акваториях Дальнего Востока

Table 9. Significant relationships (MIC values $\geqslant 0.9$ ) between environmental factors and fish biomass in marine areas of the Far East

\begin{tabular}{|c|c|c|c|c|c|c|c|c|c|c|c|c|c|c|c|c|}
\hline \multirow{2}{*}{ Вид, группировка } & \multicolumn{15}{|c|}{ Факторы среды } & \multirow{2}{*}{$\begin{array}{c}\text { Количество } \\
\text { значимых } \\
\text { факторов } \\
\text { среды }\end{array}$} \\
\hline & 1 & 2 & 3 & 4 & 5 & 6 & 7 & 8 & 9 & 10 & 11 & 12 & 13 & 14 & 15 & \\
\hline Минтай анадырско-наваринский & & & + & + & + & + & + & & + & + & + & + & & & + & 10 \\
\hline Минтай северо-восточного Сахалина & & & + & + & + & & + & & & + & + & + & + & + & + & 10 \\
\hline Минтай западноберинговоморский & & & + & + & + & + & + & & & + & + & + & & & + & 9 \\
\hline $\begin{array}{l}\text { Минтай восточноберинговоморский } \\
\text { (США) }\end{array}$ & & & + & + & & & + & & & + & + & + & & & + & 7 \\
\hline Минтай восточноохотоморский & & & + & & & & + & & & + & + & + & & & + & 6 \\
\hline Минтай Японского моря (Приморье) & + & + & & & & & & & & + & & & & & + & 4 \\
\hline Минтай восточнокамчатский & & & + & & & & + & & & & & & & & + & 3 \\
\hline Треска анадырско-наваринская & & & + & + & + & & + & & & + & + & + & & & + & 8 \\
\hline Треска карагинская & & & + & + & & + & + & & + & & & + & & & + & 7 \\
\hline Треска западнокамчатская & & & & & & & + & & & + & + & + & + & + & + & 7 \\
\hline Треска южнокурильская & & & + & + & + & & + & & & & & & & & + & 5 \\
\hline Треска западносахалинская & & & + & & & & & & & & + & + & & & & 3 \\
\hline Треска восточнокамчатская & & & & & & & + & & & & & & & & + & 2 \\
\hline Навага карагинская & & & + & + & & & & & + & & + & + & & & + & 6 \\
\hline $\begin{array}{l}\text { Навага залива Терпения (вост. } \\
\text { Сахалин) }\end{array}$ & & & + & & & & + & & & & & + & + & + & + & 6 \\
\hline Навага западнокамчатская & & & & & & & & & & + & + & + & + & & + & 5 \\
\hline $\begin{array}{l}\text { Терпуг северный одноперый вост. } \\
\text { Камчатки и сев. Курил }\end{array}$ & & & + & + & & + & + & & & + & + & + & & & + & 8 \\
\hline $\begin{array}{l}\text { Терпуг южный одноперый южных } \\
\text { Курил }\end{array}$ & & & & & & & + & & & & & + & & & + & 3 \\
\hline $\begin{array}{l}\text { Камбала двухлинейная } \\
\text { восточнокамчатская }\end{array}$ & & & + & & + & + & + & & + & & & & & & + & 6 \\
\hline $\begin{array}{l}\text { Камбала желтопёрая } \\
\text { западнокамчатская }\end{array}$ & & & + & & & & & & & + & + & + & & + & + & 6 \\
\hline Камбала желтопёрая карагинская & & & & + & & + & + & & & & + & + & & & & 5 \\
\hline $\begin{array}{l}\text { Камбала желтопёрая залива } \\
\text { Терпения (вост. Сахалин) }\end{array}$ & & & & & & & & & & + & + & + & & + & & 4 \\
\hline $\begin{array}{l}\text { Камбала желтопёрая } \\
\text { западносахалинская }\end{array}$ & & & & & & & & & & & + & & & & & 1 \\
\hline $\begin{array}{l}\text { Сельдь восточноберинговоморская } \\
\text { (США) }\end{array}$ & & & + & + & + & + & + & & + & + & + & + & & & + & 10 \\
\hline Сельдь гижигинско-камчатская & & & + & & & & + & & & + & & + & + & + & & 6 \\
\hline
\end{tabular}


Окончание табл. 9

\begin{tabular}{|c|c|c|c|c|c|c|c|c|c|c|c|c|c|c|c|c|}
\hline \multirow{2}{*}{ Вид, группировка } & \multicolumn{15}{|c|}{ Факторы среды } & \multirow{2}{*}{$\begin{array}{c}\text { Количество } \\
\text { значимых } \\
\text { факторов } \\
\text { среды }\end{array}$} \\
\hline & 1 & 2 & 3 & 4 & 5 & 6 & 7 & 8 & 9 & 10 & 11 & 12 & 13 & 14 & 15 & \\
\hline $\begin{array}{l}\text { Сельдь восточноберинговоморская } \\
\text { (РФ) }\end{array}$ & & & & & & + & & & + & & + & + & & & + & 5 \\
\hline Сельдь корфо-карагинская & & & & & & + & & & + & & + & + & & & & 4 \\
\hline Сельдь охотская & & & + & & & & & & & + & + & + & & & & 4 \\
\hline
\end{tabular}

Примечание. Факторы среды [Datsky et al., 2021: табл. 1]: 1 - атмосферное давление, мбар; 2 - относительная влажность воздуха, \%; 3 температура воды (поверхность), $\mathrm{t}^{\circ} \mathrm{C} ; 4-$ температура воды (у дна), t ${ }^{\circ} \mathrm{C} ; 5$ - аномалии температуры воды (слой 50 м), t ${ }^{\circ} \mathrm{C} ; 6$ - аномалии температуры воды (у дна), ${ }^{\circ} \mathrm{C} ; 7$ - ледовитость, \%; 8 - ледовитость (площадь льдов), км²; 9 - цветение фитопланктона (кокколитофоры), тыс. км²; 10 - биомасса мелкой фракции зоопланктона, мг/куб. м; 11 - биомасса средней фракции зоопланктона, мг/куб. м; 12 - биомасса крупной фракции зоопланктона, мг/куб. м; 13 - биомасса сагитт, млн т; 14 - биомасса эвфаузиид, млн т; 15 - солнечная активность, число Вольфа, W. Пустые ячейки - данные отсутствуют, данные есть, но МИК < 0,9. Группировки видов даны в порядке снижения количества значимых факторов среды, сопряженных с обилием рыб.

Наибольшее количество факторов среды, сопряженных с биомассой рыб, выявлено у минтая и наваги Берингова моря и вод восточного Сахалина, трески и желтопёрой камбалы Берингова моря и акватории западной Камчатки, сельди восточноберинговоморской и гижигинско-камчатской (табл. 9). Для формирования обилия почти всех группировок минтая самыми значимыми оказались температура поверхности воды и ледовитость (что объяснимо, см. табл. 7), биомасса мелкой и прочих фракций зоопланктона. У трески важным фактором, помимо указанных выше, являлась температура воды у дна. Отметим также значимость для всех анализируемых рыб присутствия средней и крупной фракций зоопланктона. Отдельно следует упомянуть силу связи между числами Вольфа, определяющими солнечную активность, и биомассой рыб с различной временной задержкой [Datsky et al., 2021: табл. 4]. Несмотря на отсутствие в настоящее время чёткого физического обоснования механизмов влияния солнечной активности на земные процессы [Колесник, 2002 б], найденные закономерности могут представлять научный интерес в будущем. Такие связи с обилием рыб сильны (МИК $\geqslant 0,9)$ у 21 единицы запасов из 28 (табл. 9), среди которых все группировки минтая и наваги, треска Берингова и Охотского морей и прилегающей акватории Тихого океана, восточноберинговоморская сельдь, камбалы желтопёрая западнокамчатская и двухлинейная, два вида терпугов. Напротив, сравнительно низкие связи солнечных циклов и биомасс обнаружены для сельдей Охотского и юго-западной части Берингова морей, желтопёрой камбалы карагинской, западного и восточного Сахалина, западносахалинской трески.

Так, если отключить оптимизацию псевдоузлов тонкоплёночного сплайна в пакете mgcv через обобщённую кросс-валидацию и назначить их размер- ность $(k)$ равной 20, то только по одному из предикторов (ледовитость Охотского моря в декабре-мае 3 года назад) доля описанной дисперсии вырастет до $53,1 \%$, что гораздо выше, чем у финальной ОЛМ (29,2\%). При этом есть важные последствия такой настройки. Во-первых, форму сплайна будет невозможно интерпретировать (рис. 16), во-вторых, её ВIC будет существенно выше (706), чем у ОЛМ (662). Другими словами, ОАМ здесь формально хуже ОЛМ: она имеет меньше обобщающей способности, несмотря на лучшее схождение с наблюдениями. Если также неправильно настроить ОАМ, зафиксировав размерность сплайнов на 20 , а не оптимизировать её ещё и со вторым членом ОЛМ (число Вольфа 4 года назад), то доля описанной дисперсии достигнет 91,6\%, но сплайны потеряют статистическую значимость $(p>0,1)$. В целом, при сознательной настройке ОАМ без оптимизации измерений сплайнов, например, через кросс-валидацию, модельную кривую по динамике промысловой биомассы минтая можно провести абсолютно точно, но смысловой нагрузки она нести не будет. Авторам такой идеально проходящей по наблюдениям ОАМ будет трудно объяснить сплайны в виде «кардиограмм» вместо простых и понятных эффектов (линейных, квадратичных или других более интерпретируемых), а прогнозы такой ОАМ в перспективе приведут к значительным ошибкам.

Таким образом, если по отдельности связи, согласно МИК, определялись как нелинейные, что и наблюдается при настройке ОАМ (рис. 16), то в совместном их сочетании в логарифмическом масштабе с оптимизацией числа измерений сплайнов, последние оказались равны 1 (стали линейными, но в логарифмическом масштабе). Так, ОАМ стала ОЛМ, которая описывается формулами 1-6 и рассчитанными на их основе параметрами модели (табл. 11): 
ANDREY V. DATSKY, VLADIMIR V. KULIK, SOFIA A. DATSKAYA

THE DYNAMICS OF THE ABUNDANCE OF COMMERCIAL FISH IN THE FAR EASTERN SEAS AND ADJACENT AREAS OF THE OPEN PART OF THE PACIFIC OCEAN AND FACTORS INFLUENCING IT

Таблица 10. Особенности формирования обилия рыб в дальневосточных морях и прилегающих акваториях

Table 10. Features of the formation of the abundance of fish in the Far Eastern seas and adjacent waters

\begin{tabular}{|c|c|c|c|}
\hline Район & $\begin{array}{c}\text { Виды со сходной } \\
\text { динамикой биомассы }\end{array}$ & $\begin{array}{c}\text { Виды с противоположной } \\
\text { динамикой биомассы }\end{array}$ & Пояснение \\
\hline $\begin{array}{l}\text { Северо-западная } \\
\text { часть Берингова моря } \\
\text { (анадырско-наваринский } \\
\text { район) }\end{array}$ & минтай - треска & $\begin{array}{l}\text { минтай - сельдь } \\
\text { треска - сельдь }\end{array}$ & $\begin{array}{l}\text { Рост обилия сельди приводит } \\
\text { к росту запасов минтая через } \\
2-4 \text { года, после этого запасы } \\
\text { сельди снижаются }\end{array}$ \\
\hline $\begin{array}{l}\text { Юго-западная часть } \\
\text { Берингова моря (корфо- } \\
\text { карагинский район) }\end{array}$ & $\begin{array}{l}\text { минтай - треска } \\
\text { треска - навага (до } 2010 \text { г.) } \\
\text { треска - желтопёрая камбала } \\
\text { навага - сельдь (после } 2010 \text { г.) } \\
\text { желтопёрая камбала - сельдь }\end{array}$ & $\begin{array}{l}\text { минтай - сельдь } \\
\text { минтай - желтопёрая камбала } \\
\text { треска - сельдь } \\
\text { навага - сельдь (до } 2010 \text { г.) }\end{array}$ & $\begin{array}{l}\text { Динамика биомассы тре- } \\
\text { ски имеет высокое сходство } \\
\text { с минтаем с запаздыванием } \\
\text { на 4-5 лет }\end{array}$ \\
\hline $\begin{array}{l}\text { Северо-западная часть } \\
\text { Тихого океана (у юго- } \\
\text { восточного побережья } \\
\text { Камчатки, северных } \\
\text { Курильских островов) }\end{array}$ & минтай - треска & $\begin{array}{l}\text { минтай - северный однопёрый } \\
\text { терпуг } \\
\text { минтай - двухлинейная кам- } \\
\text { бала } \\
\text { треска - северный однопёрый } \\
\text { терпуг } \\
\text { треска - двухлинейная кам- } \\
\text { бала }\end{array}$ & $\begin{array}{l}\text { Динамика биомассы тре- } \\
\text { ски имеет высокое сходство } \\
\text { с минтаем с запаздыванием } \\
\text { на 5-7 лет }\end{array}$ \\
\hline $\begin{array}{l}\text { Северо-западная часть } \\
\text { Тихого океана (у южных } \\
\text { Курильских островов) }\end{array}$ & $\begin{array}{l}\text { треска - южный однопёрый } \\
\text { терпуг } \\
\text { (до } 2000 \text { г.) }\end{array}$ & $\begin{array}{l}\text { треска - южный однопёрый } \\
\text { терпуг (после } 2000 \text { г.) }\end{array}$ & - \\
\hline $\begin{array}{l}\text { Северо-восточная часть } \\
\text { Охотского моря } \\
\text { (преимущественно } \\
\text { у западной Камчатки) }\end{array}$ & $\begin{array}{l}\text { минтай - треска (до } 2012 \text { г.) } \\
\text { минтай - желтопёрая камбала } \\
\text { (до } 2006 \text { г.) } \\
\text { треска - навага } \\
\text { треска - желтопёрая камбала }\end{array}$ & $\begin{array}{l}\text { минтай - сельдь } \\
\text { минтай - треска (после } 2012 \text { г.) } \\
\text { минтай - желтоперая камбала } \\
\text { (после } 2006 \text { г.) } \\
\text { треска - сельдь } \\
\text { желтоперая камбала - сельдь } \\
\text { навага - сельдь }\end{array}$ & - \\
\hline $\begin{array}{l}\text { Охотское море } \\
\text { (у северо-восточного } \\
\text { Сахалина, } \\
\text { залив Терпения) }\end{array}$ & $\begin{array}{l}\text { минтай - сельдь (после } 2001 \text { г.), } \\
\text { минтай - треска (до } 1993 \text { г.) }\end{array}$ & $\begin{array}{l}\text { минтай - сельдь (до } 2001 \text { г.) } \\
\text { минтай - треска (после } 1993 \text { г.) } \\
\text { минтай - желтопёрая камбала } \\
\text { треска - сельдь } \\
\text { треска - желтопёрая камбала }\end{array}$ & - \\
\hline $\begin{array}{l}\text { Японское море } \\
\text { (у западного Сахалина } \\
\text { и Приморья) }\end{array}$ & $\begin{array}{l}\text { минтай - треска } \\
\text { треска - желтопёрая камбала }\end{array}$ & - & - \\
\hline
\end{tabular}

$$
\begin{gathered}
B_{i} \sim \operatorname{Gamma}\left(\mu_{i}, v\right) ; \\
E\left(B_{i}\right)=\mu_{i}=e^{\eta_{i}} ; \\
g\left(\mu_{i}\right)=\ln \left(\mu_{i}\right) ; \\
\operatorname{Var}\left(B_{i}\right)=\varphi \mu_{i}^{2} ; \\
\varphi=\sigma^{2}=v^{-1} ; \\
\eta_{i}=\beta_{0}+\beta_{1} \mathrm{x}_{i}+\beta_{2} \mathrm{y}_{i},
\end{gathered}
$$

где $B$ - промысловая биомасса, тыс. т; Gamma - распределение гамма с параметрами $\mu_{\mathrm{i}}, v ; E$ - математическое ожидание; $\eta$ - линейный предиктор, $g$ - функция связи с наблюдениями; Var - дисперсия с параметром $\varphi, \beta_{0}, \beta_{1}$ и $\beta_{2}$ - параметры ОЛМ, $x$ - ледови- тость Охотского моря 3 года назад в декабре-мае, \%; y - число Вольфа 4 года назад.

Отметим здесь, что по отдельности корреляция Пирсона между натуральным логарифмом промысловой биомассы минтая и предикторами х и у слаба: $r\left(\ln \left(B_{\mathrm{i}}\right), \ln \left(\mathrm{x}_{\mathrm{i}}\right)\right)=0,34$ и статистически незначима $r\left(\ln \left(B_{\mathrm{i}}\right), \ln \left(\mathrm{y}_{\mathrm{i}}\right)\right)=-0,21(p>0,16)$, а в ОЛМ все найденные коэффициенты имеют высокую статистическую значимость ( $p<0,0001)$. При этом в целом доля описанной дисперсии равна 29,2\%, а корреляция в естественном масштабе между рядами $r(\mathrm{~B}, \mathrm{E}(\mathrm{B})=0,57$. Таким образом, МИК действительно позволил найти предикторы, которые в классическом поиске через корреляции были бы пропущены (их эффекты линейны, но в совокупности в логарифмическом масштабе, а не по отдельности). Предсказанные значения $\mathrm{E}(\mathrm{B})$ по формуле показаны на рис. 17. 


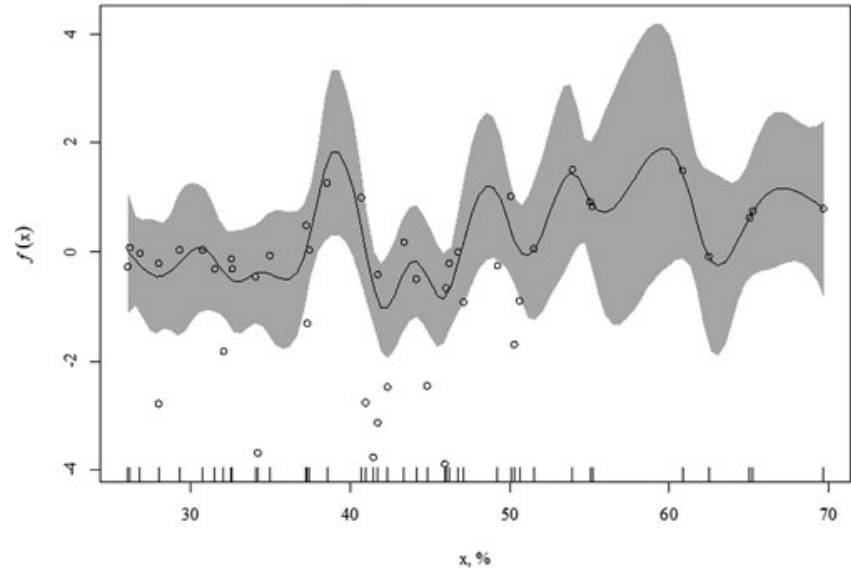

Рис. 16. Ответ фиксированного сплайна в обобщенных аддитивных моделях (ОАМ) для прогноза промысловой биомассы минтая у северо-восточного Сахалина (по оси ординат) в зависимости от ледовитости Охотского моря 3 года назад в декабре-мае (по оси абсцисс,\%) [по: Пищальник и др., 2016; 2020]

Fig. 16. The answer of a fixed spline in generalized additive models (GAM) for forecasting the commercial biomass of walleye pollock off northeastern Sakhalin (on the ordinate) depending on the ice extent of the Sea of Okhotsk 3 years ago in December-May (on the abscissa,\%) [by: Pischalnik et al., 2016, 2020]

Следуя вышесказанному, из множества вероятных сильных парных нелинейных связей биомассы минтая у северо-восточного Сахалина с различными лагами потенциальных предикторов оптимальной оказалась ОЛМ, содержащая всего два предиктора, но с логлинейными отношениями. Сходных результатов, вероятно, можно ожидать и в других случаях. Следовательно, приведённые в приложении оценки МИК [Datsky
Таблица 11. Найденные параметры обобщённой линейной модели (ОЛМ) и их неопределённость

Table 11. The found parameters of the generalized linear model (GLM) and their uncertainty

\begin{tabular}{ccc}
\hline Параметр & Оценка параметра & $\begin{array}{c}\text { Стандартное отклонение, } \\
\text { оценки }\end{array}$ \\
\hline$\beta_{0}$ & 5,175160 & 0,419540 \\
\hline$\beta_{1}$ & 0,037998 & 0,009786 \\
\hline$\beta_{2}$ & $-0,006684$ & 0,001789 \\
\hline
\end{tabular}

et al., 2021: табл. 2, 3] не должны восприниматься как руководство к включению всех потенциальных предикторов в ОАМ для каждого запаса, а служат преимущественно для уточнения их стартовых наборов в целях последующего поиска оптимальных ОАМ, ОлМ или более сложных методов, например, машинного обучения. Таким образом, найденные сильные МИК особенно там, где корреляция близка к нулю, призваны воодушевить исследователей к проведению более детальных анализов, чем обычные линейные модели.

\section{ЗАКЛЮЧЕНИЕ}

Динамика численности гидробионтов зависит от множества факторов, которые можно сгруппировать в естественные абиотические (климато-океанологические, геофизические) и биотические (кормовая база, хищники, паразиты), популяционно-генетические, эндогенные и антропогенные (промысел, загрязнение среды обитания и т.п.). Совместный учет всех этих факторов в идеале должен привести исследователя

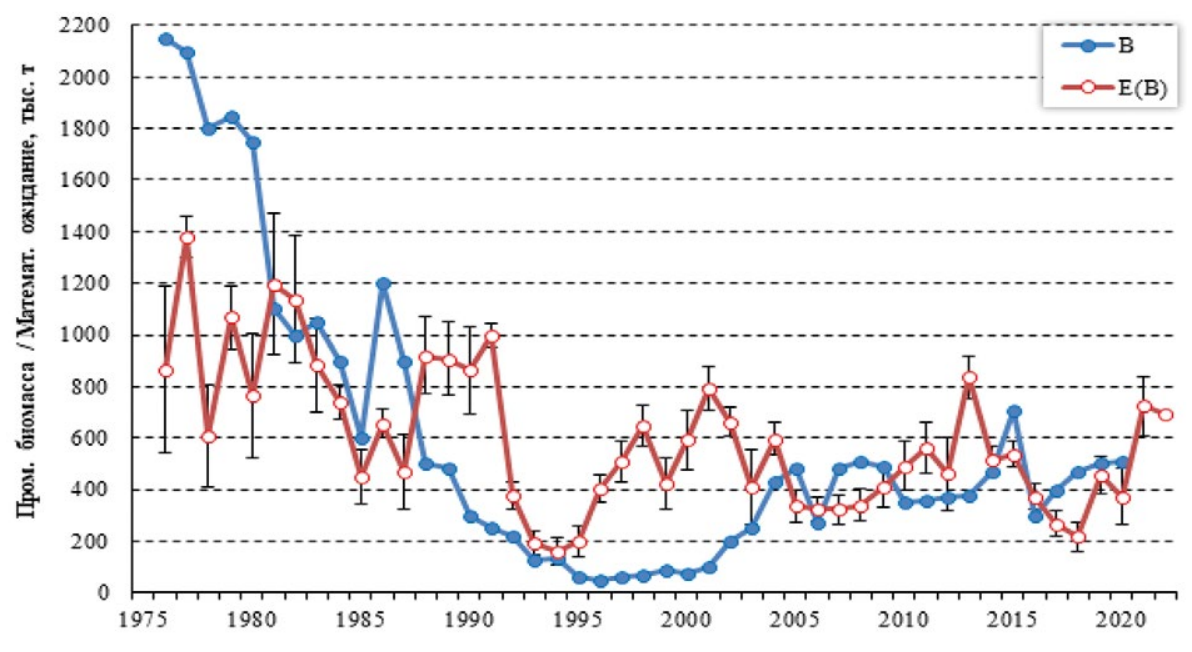

Рис. 17. Биомасса промыслового запаса минтая (В, тыс. т) у северо-восточного Сахалина и её математическое ожидание $\mathrm{E}(\mathrm{B})$. Усами показана стандартная ошибка

Fig. 17. Biomass of the commercial stock of walleye pollock ( $B$, thousand tons) in northeastern Sakhalin and its mathematical expectation $E(B)$. Mustache shows standard error 
к пониманию причин флюктуации численности рыб и достоверному прогнозу их вылова на ближайшую и долгосрочную перспективы. При этом следует признать слабую изученность отдельных сторон жизни гидробионтов и их окружения. Особенно это касается генетических и физиологических особенностей отдельных организмов и групп особей, а также начального периода их жизни. Очевидно, что именно осмысление эндогенных процессов в популяциях вкупе с изучением кормовой базы (простейшие, бактерии, миктофиты и т.п.) молоди (личинок, мальков) и обеспеченность ею ранних стадий рыб, позволит сделать качественный скачок в постижении природы периодических колебаний численности гидробионтов.

В то же время современные реалии в рыбной отрасли таковы, что результат нужен здесь и сейчас, а времени для многолетних и финансово затратных исследований нет. В этом случае представляется единственно верным обобщение всей имеющейся информации по обилию рыб и их окружению, позволяющее достоверно охарактеризовать состояние гидробионтов во времени. Важно отметить, что настоящим исследованием по единой методике были охвачены региональные группировки массовых рыб, которые, помимо своей рыбопромысловой значимости (на их долю приходится до 80\% вылова в дальневосточных морях и прилегающих к ним акваториях), относятся к видам с различной жизненной стратегией (пелагические, донно-придонные, анадромные). Последнее подразумевает, что такие объекты могут по-разному реагировать на одни и те же факторы среды. Полагая, что основное воздействие природной среды приходится на молодь рыб, дальнейший рост которых в случае появления урожайных поколений и приводит к пикам биомасс, на основе современных информационных технологий были выделены скоррелированные с обилием морских рыб базовые факторы, которые в дальнейшем могут использоваться в целях прогнозирования. Здесь необходимо отметить, что любые индексы сами по себе не «вскрывают» механизмы влияния условий среды. Именно поэтому в данной работе был использован максимальный информационный коэффициент, который статистически тонко и зачастую более надежно указывает на многочисленные и сложные связи факторов среды и биоты, нежели стандартные коэффициенты и индексы. По сути используемые в настоящее время модели прогнозирования, которые часто формальны и не всегда учитывают особенности биологии рыб и условия их обитания, могут быть скорректированы влиянием факторов среды, а, значит, приблизятся в своих результатах к реальности.
В целом природные связи с определённой периодичностью вызывают особый интерес в свете возможного прогнозирования уловов морских рыб. Весь накопленный запас знаний о внешних оболочках Земли (в первую очередь атмосфера и гидросфера) показывает сложную многопараметрическую систему, в которой наблюдаются колебательные процессы. Часть колебаний задана годичными изменениями условий инсоляции разных участков земной поверхности и соответствующими изменениями многих параметров. Другая часть связана с вращением Земли, перемещениями атмосферных масс, циркуляцией в земной атмосфере, циклонической деятельностью. Сочетание многих земных факторов и наложенного внешнего воздействия вызывает колебательные (циклические) процессы, периодичность которых зависит от инерционности компонентов системы [Язев и др., 2009]. Иными словами, природе свойственна пульсация разнообразных геофизических параметров, имеющих различные периоды и интенсивность. К примеру, в повторяемости сейсмической активности, атмосферных и льдообразовательных процессов, температурных режимов воздушных и водных масс выявлена преобладающая цикличность 8-11 лет (в меньшей степени 18-20 лет). Вполне закономерным представляется и соответствующий отклик живой природы посредством синхронизации существующих гелиогеофизических колебательных процессов соответствующих периодов.

Согласно ведущей концепции гелиобиофизики ритмические колебания гелиогеомагнитных показателей завели «биологические часы» и в процессе эволюции интегрировались в эндогенную ритмику биологических систем. При этом многие биоритмы синхронизируются геофизическими колебательными процессами соответствующих периодов [Бреус, 2003; Малоземов, 2016]. На уровне систем организмов хорошо известны колебания численности некоторых популяций. Эти «волны жизни» наиболее чётко наблюдаются с периодами около 3-4 и 10 лет. В некотором роде, подтверждением этому явились результаты настоящего исследования, когда в формировании максимумов обилия морских рыб, исключая тихоокеанских лососей, выявлена осредненная периодичность в пределах 6-13 лет (у пелагической сельди 6-8 лет, у прочих видов - 9-13 лет). В то же время у лососей (как и в появлении урожайных поколений большинства исследованных рыб) отмечена 3-7-летняя цикличность пиков обилия, что, по-видимому, может указывать на большую их чувствительность к воздействию природной среды.

Важным итогом исследования можно считать также тот факт, что по причине региональности воз- 
действия абиотических и прочих факторов в дальневосточных морях и прилегающих к ним акваториям Тихого океана, в динамике запасов рыб различных группировок в пределах одного вида выявлена отличная друг от друга цикличность в формировании их обилия. К примеру, у трески, обитающей у берегов западного Сахалина, максимумы продуктивности формировались в среднем на 2,4 года чаще, нежели у карагинской трески, а у охотской сельди относительно восточноберинговоморской - на 1,5 года. По этой причине обобщения на материале, включающем в себя осреднённые данные по многолетней динамике биомассы любого вида, обитающего на обширной акватории, вероятнее всего покажут отличные от реальности результаты и могут привести к неверным выводам в ходе прогнозирования уловов рыб.

Среди используемых в работе факторов среды, тесно связанных с обилием региональных группировок морских рыб, наиболее часто встречающимися были температура воды в различных горизонтах (от поверхности до дна), ледовитость, цветение фитопланктона, биомасса различных фракций и видов зоопланктона и солнечная активность. Максимальное количество таких факторов выявлено у группировок минтая и наваги Берингова моря и вод восточного Сахалина, трески и желтопёрой камбалы Берингова моря и акватории западной Камчатки, сельди восточноберинговоморской и гижигинско-камчатской. Для формирования обилия большинства группировок минтая наиболее значимыми оказались поверхностная температура воды, ледовитость, биомасса мелкой и прочих фракций зоопланктона, у трески дополнительно и температура воды у дна. Отметим также важность для всех анализируемых рыб доступного наличия средней и крупной фракций зоопланктона, основных кормовых ресурсов для молоди и впервые созревающих особей. Среди прочих причин флюктуации численности объектов исследования необходимо учитывать и взаимовлияние отдельных видов посредством хищничества и соперничества за сходную кормовую базу, а также антропогенное воздействие. В последнем случае, принимая во внимание незначительное загрязнение дальневосточных морей [Динамика..., 2000; Патин, 2008; Лукьянова и др., 2018], за исключением некоторых прибрежных районов Японского моря [Ростов и др., 2016], вмешательство человека в основном заключается в осуществлении промышленного и иных видов рыболовства. При этом настоящие исследования показали незначительное его влияние на обилие рыб на современном этапе: у большинства из них при росте биомассы уловы увеличиваются незначительно или даже снижаются.
В целом вопрос использования факторов окружающей морских рыб природной среды в прогнозировании их уловов является чрезвычайно актуальным ещё и по той причине, что гелиогеофизические и климато-океанологические явления на Земле изучаются довольно давно. В ходе многочисленных исследований выявлены закономерности в периодичности таких явлений, что позволило сформировать перспективные прогнозы, точность которых в отдельных случаях достигает $88 \%$ [Плотников и др., 2019]. В отношении биологических систем всё сложнее: помимо коротких временных рядов данных, прогнозирование численности рыб затруднено дополнительными сложными многофакторными связями [Радченко, 2015; Горбатенко, 2018], сложившимися в морских экосистемах в целом и рыбных сообществах в частности. Не следует забывать и о влиянии на биоту хищников, паразитов и болезней, а также о действии популяционных и эндогенных факторов. В последнем случае, физиологическое и генетическое состояние животных при различной численности существенно отличается, а при достижении максимумов обилия в действие вступают нейроэндокринные механизмы авторегуляции, начинаются демографические перестройки в популяциях, приводящие к изменению их биотического потенциала [Шварц, 1969; Чернявский, 1984; 2007]. В целом циклы как комплексное биологическое явление есть результат достаточно длительной сопряжённой эволюции морских рыб, других компонентов экосистемы, абиотических факторов среды, и прогнозирование уловов возможно при учёте наибольшего числа переменных.

Применённый в настоящей работе метод прогнозирования через использование МИК как раз и позволяет найти предикторы, которые в классическом поиске через корреляции были бы пропущены, и его применение видится перспективным при условии использования точных первичных данных для последующих расчётов. Такие данные должны быть максимально приближены к срокам и районам обитания рыб с обязательным учётом действия факторов среды на наиболее уязвимые онтогенетические группы (от икры до годовалых особей). В качестве примера важности сбора подобной информации можно привести классификацию суровости зим на основе многолетних материалов по ледовым условиям дальневосточных морей, где в зависимости от района сбора данных зима в пределах одного года варьировала как мягкая, умеренная и суровая [Думанская, 2017]. Вполне предсказуемо, что во всех трёх случаях результаты прогнозирования уловов рыб будут значимо отличаться. 
Решение проблемы точной фиксации факторов среды в пределах обитания морских рыб и их тонкой настройки на предмет влияния на обилие гидробионтов крайне важно и по причине возможных грядущих климатических перестроек на Земле. Поскольку вариации климата определяются долговременным дисбалансом поступающей в верхние слои земной атмосферы энергии солнечного излучения и уходящей суммарной энергии от Земли обратно в космос, после максимума 24-го солнечного цикла прогнозируется переходный от глобального потепления к глубокому похолоданию период нестабильных климатических изменений. В данном случае ориентировочно в 2042 11 г. намечается наступление глубокого квазидвухвекового минимума солнечной постоянной, а в 2055 11 г. (по причине инерции Мирового океана в отдаче накопленной солнечной энергии в течение $14 \pm 6$ лет) - наступления Малого ледникового периода [Абдусаматов, 2012]. Вероятность такого прогноза прослеживается в отдельных работах [Гудкович и др., 2013; Жеребцов и др., 2013]. Подобные изменения климата приведут и к перестройкам в морских экосистемах, включая рыбные сообщества, что в полной мере отразится на распределении ресурсов рыб и их обилии. И в этом случае выявление достоверных механизмов многофакторного влияния природной среды на морскую биоту позволит спрогнозировать грядущие изменения и снивелировать их возможные последствия в рамках деятельности рыбной отрасли и перспектив развития рыболовства. Наилучшие результаты здесь можно получить посредством междисциплинарных исследований с использованием современных судов и аппаратуры, коммуникационных и компьютерных технологий, стремительно развивающихся в последние годы.

В текущий момент достоверное долгосрочное прогнозирование обилия морских рыб на фоне имеющихся знаний и сложности учёта многочисленных природных и прочих факторов среды, оказывающих влияние на рыбные ресурсы, представляется затруднительным. В то же время выявленные в настоящей работе закономерности в периодичности формирования биомассы отдельных видов и их региональных группировок позволят скорректировать методологию краткосрочного прогнозирования (до 2-3 лет) сырьевой базы рыб дальневосточных морей и прилегающих районов открытой части Тихого океана.

\section{Конфликт интересов}

Авторы заявляют об отсутствии у них конфликта интересов.

\section{Соблюдение этических норм}

Все применимые этические нормы соблюдены.

\section{Финансирование}

Работа не имела дополнительного спонсорского финансирования.

\section{ЛИТЕРАТУРА}

Абдусаматов Х.И. 2012. Двухвековое уменьшение солнечной постоянной приводит к несбалансированному тепловому бюджету Земли и глубокому похолоданию климата // Кинематика и физика небесных тел. Т. 28, № 2. С. 22-33.

Антонов Н.П. 1991. Биология и динамика численности восточнокамчатского минтая: Автореф. дисс. ... канд. биол. наук. Владивосток: ТИНРО. 23 с.

Антонов Н.П. 2011. Промысловые рыбы Камчатского края: биология, запасы, промысел. М.: ВНИРО. 244 с.

Антонов Н.П. 2013. Треска Gadus macrocephalus прикамчатских вод // Тихоокеанская треска дальневосточных вод России / Под ред. А.М. Орлова. М.: Изд-во ВНИРО. С. 133151.

Антонов Н.П., Датский А.В. 2019. Использование сырьевой базы морских рыб в Дальневосточном рыбохозяйственном бассейне в 2018 г. // Рыбное хозяйство. № 3. С. 6676.

Антонов Н.П., Датский А.В., Мазникова О.А., Митенкова Л.В. 2016. Современное состояние промысла тихоокеанской сельди в дальневосточных морях // Рыбное хозяйство. № 1. С. 54-58.

Антонов Н.П., Золотов О.Г. 1987. Особенности размножения восточнокамчатского минтая // Популяционная структура, динамика численности и экология минтая. Владивосток: ТИНРО. С. 123-132.

Антонов Н.П., Кузнецова Е.Н. 2018. Современное состояние использования сырьевой базы дальневосточных камбал // Рыбное хозяйство. № 5. С. 56-61.

Атлас распространения в море различных стад тихоокеанских лососей в период весенне-летнего нагула и преднерестовых миграций. 2002. М.: ВНИРО. 190 с.

Бабаян В.К. 2000. Предосторожный подход к оценке общего допустимого улова (ОДУ). Анализ и рекомендации по применению. М.: Изд-во ВНИРО. 190 с.

Бабаян В.К., Васильев Д.А., Варкентин А.И., Сергеева Н.П. 2006. Методические особенности обоснования ОДУ минтая в условиях неопределенности // Труды ВНИРО. Т. 146. C. 13-37.

Балыкин П.А. 1993. Изменчивость сроков нереста и смертность развивающейся икры у западноберинговоморского минтая (Theragra chalcogramma (Pallas)) // Исследование биологии и динамики численности промысловых рыб камчатского шельфа. Вып. 2. Петропавловск-Камчатский: КоТИНРО. С. 166-176.

Балыкин П.А. 2006. Ихтиоцены западной части Берингова моря: состав, промысловая значимость и состояние запасов: Автореф. дисс. ... докт. биол. наук. М.: ВНИРО. 50 с.

Балыкин П.А., Варкентин А.И. 2002. Распределение икры, личинок и сеголеток минтая Theragra chalcogramma 
(Gadidae) в северо-западной части Берингова моря // Вопросы ихтиологии. Т. 42, № 6. С. 798-805.

Балыкин П.А., Золотов А.О. 2010. Межвидовые отношения гидробионтов как фактор динамики численности // Исследования водных биологических ресурсов Камчатки и северо-западной части Тихого океана. Вып. 17. С. 24-29.

Беринговоморская минтаевая путина - 2017 (путинный прогноз). 2017. Владивосток: ТИНРО-Центр. 71 с.

Борец Л.А. 1997. Донные ихтиоцены российского шельфа дальневосточных морей: состав, структура, элементы функционирования и промысловое значение. Владивосток: ТИНРО-Центр. 217 с.

Бореи Л.А., Степаненко М.А., Николаев А.В., Грицай Е.В. 2002. Состояние запасов минтая в наваринском районе Берингова моря и причины, определяющие эффективность его промысла // Известия ТИНРО. Т. 130, ч. III. С. 1001-1014.

Бреус Т.К. 2003. Влияние солнечной активности на биологические объекты: Автореф. дисс. ... докт. физ.-мат. наук. М.: ИКИ РАН. 32 с.

Бугаев В.Ф. 2011. Азиатская нерка-2 (биологическая структура и динамика численности локальных стад в конце XX - начале XXI вв.). Петропавловск-Камчатский: Изд-во Камчатпресс. 380 с.

Бугаев В.Ф., Вронский Б.Б., Заварина Л.О., Зорбиди Ж.Х., Остроумов А.Г., Тиллер И.В. 2007. Рыбы реки Камчатка. Петропавловск-Камчатский: Изд-во КамчатНИРО. 459 с.

Булатов О.А. 1986. Распределение икры и личинок тресковых (подсемейство Gadinae) в тихоокеанских водах Камчатки и западной части Берингова моря // Тресковые дальневосточных морей. Владивосток: ТИНРО. С. 89-102.

Булатов О.А. 1987. Икра и личинки минтая в восточной части Берингова моря // Популяционная структура, динамика численности и экология минтая. Владивосток: ТИНРО. С. $100-114$.

Булатов О.А. 2004. Минтай (Theragra chalcogramma) Берингова моря: размножение, запасы и стратегия управления промыслом: Автореф. дисс. ... докт. биол. наук. М.: ВНИРО. $49 \mathrm{c}$.

Булатов О.А. 2014. Промысел и запасы минтая: возможна ли турбуленция? // Вопросы рыболовства. Т. 15, № 4. С. 350390.

Булатов О.А. 2017. Вертикальное распределение икры и личинок минтая // Вопросы рыболовства. Т. 18, № 3. С. 269285.

Буслов А.В. 2001. Новые данные о распределении и миграциях минтая в тихоокеанских водах северных Курильских островов и юго-восточной Камчатки // Известия ТИНРО. Т. 128. С. 229-241.

Буслов А.В. 2008. Минтай восточного побережья Камчатки: современное состояние запасов и рекомендации по рациональной эксплуатации // Известия ТИНРО. Т. 152. С. 3-17.

Буслов А.В., Тепнин О.Б. 2002. Условия нереста и эмбриогенеза минтая Theragra chalcogramma (Gadidae) в глубоководных каньонах тихоокеанского побережья Камчатки // Вопросы ихтиологии. Т. 42, № 5. С. 617-625.

Буслов А.В., Тепнин О.Б., Дубинина А.Ю. 2004. Некоторые особенности экологии нереста и эмбриогенеза восточнокамчатского минтая // Известия ТИНРО. Т. 138. С. 282-298.
Варкентин А.И. 2015. Новые данные о сроках массового нереста минтая (Theragra chalcogramma) у Западной Камчатки // Исследования водных биологических ресурсов Камчатки и северо-западной части Тихого океана. Вып. 39. C. 70-74.

Вдовин А.Н., Четырбоцкий А.Н., Нуждин В.В. 2017. Динамика численности приморского минтая Theragra chalcogramma (Pallas, 1814) (Gadiformes: Gadidae) в Японском море // Биология моря. Т. 43, № 5. С. 321-328.

Вершинин В.Г. 1984. Биология и промысел трески северо-западной части Тихого океана: Автореф. дисс. ... канд. биол. наук. Владивосток: ДВНЦ АН СССР. 21 с.

Вершинин В.Г. 1987. О биологии и современном состоянии запасов трески северной части Берингова моря // Биологические ресурсы Арктики и Антарктики. М.: Наука. C. 207-224.

Винников А.В. 2008. Тихоокеанская треска Западной Камчатки: биология, динамика численности, промысел: Автореф. дисс. ... канд. биол. наук. Владивосток: ИБМ ДВО РАН. 24 с.

Волвенко И.В. 2014. Сравнение дальневосточных морей и северо-западной части Тихого океана по интегральным характеристикам траловой макрофауны пелагиали и дна // Известия ТИНРО. Т. 178. С. 58-67.

Волков А.Ф. 2014. Состояние кормовой базы тихоокеанских лососей в Беринговом море в 2003-2012 гг. (по результатам работ международных экспедиций BASIS-1 и 2) // Известия ТИНРО. Т. 179. С. 250-271.

Вышегородцев В.A. 1987. К вопросу репродуктивной изоляции североохотомрской популяции минтая // Популяционный состав, динамика численности и экология минтая. Владивосток: ТИНРО. С. 39-47.

Глубоков А.И., Алексеев Д.О., Бизиков В.А. 2000. О каннибализме минтая в северо-западной части Берингова моря в конце 90-х годов // Вопросы рыболовства. Т. 1, № 4. С. 91-97.

Горбатенко К.М. 2018. Трофодинамика гидробионтов в Охотском море: Автореф. дисс. ... докт. биол. наук. Владивосток: TИНРО. $47 \mathrm{C}$.

Горбунова Н.Н. 1954. Размножение и развитие минтая // Труды ИО АН СССР. Т. 11. С. 132-195.

Горбунова Н.Н.1959. О размножении южного одноперого терпуга // Известия ТИНРО. Т. 47. С. 145-153.

Грицай Е.В. 2006. Изменчивость размерно-возрастного состава минтая на восточно- и северо-беринговоморской шельфе // Известия ТИНРО. Т. 146. С. 84-102.

Грицай Е.В., Шейбак А.Ю. 2009. Анализ промысла и динамика размерно-возрастного состава минтая в Анадырско-Наваринском районе в 2003-2008 гг. // Известия ТИНРО.Т. 158. С. 158-186.

Гудкович З.М., Карклин В.П., Миронов Е.У., Иванов В.В., Лосев С.М., Дымент Л.Н., Смоляницкий В.М., Фролов С.В., Юлин А.В., Усольцева Е.А. 2013. Развитие ледовых и метеорологических условий в Арктике в период 2007-2013 гг. // Проблемы Арктики и Антарктики. № 2 (96). С. 90-102.

Датский А.В. 2004. Размножение минтая Theragra chalcogramma (Gadidae) в Анадырском заливе // Вопросы рыболовства. Т. 5, № 4(20). С. 597-617. 
Датский А.В., Андронов П.Ю. 2007. Ихтиоцен верхнего шельфа северо-западной части Берингова моря. Магадан: СВНЦ ДВО РАН. 261 с.

Дементьева Т.Ф. 1961. Значение решающего фактора в свете годовых и многолетних колебаний численности популяций. Труды совещания по динамике численности рыб. М.: Изд-во РАН. Вып. 13. С. 34-43.

Динамика экосистем Берингова и Чукотского морей. 2000. М.: Наука. 357 с.

Дудник Ю.И., Золотов О.Г. 2000. Распространение, особенности биологии и промысел одноперых терпугов рода Pleurogrammus (Hexagrammidae) в прикурильских водах // Промыслово-биологические исследования рыб в тихоокеанских водах Курильских островов и прилежащих районах Охотского и Берингова морей в 1992-1998 гг. М.: Изд-во ВНИРО. С. 78-90.

Думанская И.О. 2017. Ледовые условия морей азиатской части России. М.; Обнинск: ИГ-СОЦИН. 640 с.

Дьяков Б.С. 2010. Закономерности развития гидрометеорологических условий Японского моря в 1950-2009 гг. и прогноз температуры воды // Вопросы промысловой океанологии. Вып. 7. № 2. С. 102-108.

Дьяков Ю.П. 2011. Камбалообразные (Pleuronectiformes) дальневосточных морей России (пространственная организация фауны, сезоны и продолжительность нереста, популяционная структура вида, динамика популяций). Петропавловск-Камчатский: Изд-во КамчатНИРО. 433 с.

Жеребцов Г.А., Коваленко В.А., Молодых С.И., Кириченко К.Е. 2013. Влияние солнечной активности на температуру тропосферы и поверхности океана // Известия Иркутского гос. ун-та. Серия «Науки о Земле». Т. 6, № 1. С. 61-79.

Зверькова Л.М. 1969. О нересте минтая в водах западного побережья Камчатки // Вопросы ихтиологии. Т. 9, вып. 2. C. 270-275.

Зверькова Л.М. 1971. Размножение минтая у юго-западного побережья Сахалина // Известия ТИНРО. Т. 76. С. 62-75.

Зверькова Л.М. 1977. Созревание, плодовитость и районы размножения минтая Theragra chalcogramma (Pallas) в северо-восточной части Японского моря // Вопросы ихтиологии. Т. 17, вып. 3. С. 462-468.

Зверькова Л.М. 1981. Внутривидовая структура минтая в Охотском море // Экология, запасы и промысел минтая. Владивосток: ТИНРО. С. 41-56.

Зверькова Л.М. 1987. Пространственно-временная структура района воспроизводства минтая Theragra chalcogramma (Gadidae) в северной части Охотского моря // Вопросы ихтиологии. Т. 27, вып. 3. С. 414-420.

Зверькова Л.М., Пушников В.В. 1980. Распределение пелагической икры минтая в Охотском море // Рыбохозяйственные исследования умеренных вод Тихого океана. Владивосток. С. 117-123.

Золотов А.О. 2008. Использование траловых съёмок для оценки численности камбал Карагинского и Олюторского заливов: методика и результаты // Исследования водных биологических ресурсов Камчатки и северо-западной части Тихого океана. Вып. 13. С. 51-58.

Золотов А.О. 2009. Моделирование оптимального режима промысла желтоперой камбалы западной части Берингова моря // Исследования водных биологических ресурсов
Камчатки и северо-западной части Тихого океана. Вып. 11. С. 100-104.

Золотов А.О. 2011. Распределение и сезонные миграции камбал Карагинского и Олюторского заливов // Исследования водных биологических ресурсов Камчатки и северо-западной части Тихого океана. Вып. 21. С. 73-100.

Золотов А.О., Золотов О.Г., Спирин И.Ю. 2015. Многолетняя динамика биомассы и современный промысел северного однопёрого терпуга Pleurogrammus monopterygius в тихоокеанских водах Камчатки и Курильских островов // Известия ТИНРО. Т. 181. С. 3-22.

Золотов А.О., Смирнов А.В., Баранчук-Червонный Л.Н., Дубинина А.Ю. 2014. Многолетняя динамика и современное состояние запасов желтоперой камбалы Limanda aspera в водах о. Сахалин // Известия ТИНРО. Т. 178. С. 25-57.

Золотов А.О., Терентьев Д.А., Спирин И.Ю. 2013. Состав и современное состояние сообщества демерсальных рыб Карагинского и Олюторского заливов // Известия ТИНРО. T. 174. C. 85-103.

Золотов А.О., Фатыхов Р.Н. 2016. Состояние запасов и особенности промысла южного одноперого терпуга Pleurogrammus azonus Jordan et Metz (1913) в водах южных Курильских островов // Известия ТИНРО. Т. 186. C. $61-80$.

Золотов О.Г. 1975. Распределение одноперого терпуга в прибрежных водах северных Курильских островов // Известия ТИНРО. Т. 97. С. 37-43.

Золотов О.Г.1981. О половом диморфизме у северного одноперого терпуга Pleurogrammus monopterigius // Вопросы ихтиологии. Т. 21, вып. 2. С. 253-257.

Золотов О.Г. 1991. Распределение и дрейф икры и личинок минтая у западного побережья Камчатки // Исследование биологии и динамики численности промысловых рыб камчатского шельфа. Вып. 1, ч. 1. Петропавловск-Камчатский: КамчатНИРО. С. 167-182.

Золотов О.Г., Орлов А.М. 2009. Роль подводных поднятий в структуре ареала северного одноперого терпуга // Рыбное хозяйство. Вып. 6. С. 53-56.

Зорбиди Ж.Х. 2010. Кижуч азиатских стад. Петропавловск-Камчатский: КамчатНИРО, 306 с.

Ижевский Г.К. 1961. Океанологические основы формирования промысловой продуктивности морей: Монография. М.: Пищ. пром-ть. 216 с.

Ижевский Г.К. 1964. Системная основа прогнозирования океанологических условий воспроизводства рыб. М.: ВНИРО. 165 c.

Ильин О.И., Сергеева Н.П., Варкентин А.И. 2014. Оценка запасов и прогнозирование ОДУ восточнокамчатского минтая (Theragra chalcogramma) на основе предосторожного подхода // Труды ВНИРО. Т. 151. С. 62-74.

Карпенко В.И. 1998. Ранний морской период жизни тихоокеанских лососей. М.: ВНИРО. 165 с.

Качина Т.Ф. 1981. Сельдь западной части Берингова моря. М.: Лег. и пищ. пром-сть. 121 с.

Качина Т.Ф., Балыкин П.А. 1981. Нерест минтая в западной части Берингова моря // Экология, запасы и промысел минтая. Владивосток: ТИНРО. С. 63-72.

Ким Сен Ток, Бирюков И.А. 2009. Некоторые черты биологии и промысловые ресурсы донных и придонных видов рыб 


\section{А.В. ДАТСКИЙ, В.В. КУЛИК, С.А. ДАТСКАЯ}

ДИНАМИКА ОБИЛИЯ МАССОВЫХ ПРОМЫСЛОВЫХ РЫБ ДАЛЬНЕВОСТОЧНЫХ МОРЕЙ И ПРИЛЕГАЮЩИХ РАЙОНОВ ОТКРЫТОЙ ЧАСТИ ТИХОГО ОКЕАНА И ВЛИЯЮЩИЕ НА НЕЁ ФАКТОРЫ

в шельфовых водах южных Курильских островов в 1987 2006 гг. Южно-Сахалинск: СахНИРО. 124 с.

Ким Сен Ток. 2007. Современная структура и тенденции изменения ресурсов демерсальных рыб в западносахалинских водах // Известия ТИНРО. Т. 148. С. 35-56.

Ким Сен Ток. 2013. Отличительные черты биологии и ресурсы трески северо-восточной части Японского моря (западное побережье о. Сахалин) // Тихоокеанская треска дальневосточных вод России / под. ред. А.М. Орлова. М.: ВНИРО. С. 81-106.

Кляшторин Л.Б., Любушин А.А. 2005. Циклические изменения климата и рыбопродуктивности. М.: Изд-во ВНИРО. 235 с.

Колесник Ю.А. 2002 а. Неравномерность вращения Земли и её влияние на природные процессы и динамику биосистем // Известия ТИНРО. Т. 130. С. 1283-1297.

Колесник Ю.А. 2002 б. Исследование реакций биоты на многолетние изменения гелиогеофизических процессов: Автореф. дисс. ... докт. биол. наук. Владивосток: ДВГУ. 43 с.

Кровнин А.С., Антонов Н.П., Котенев Б.Н., Мурый Г.П. 2017. Влияние климата на квазидекадные изменения численности поколений трески северо-западной части Берингова моря // Труды ВНИРО. Т. 169. С. 37-50.

Кузнецов М.Ю., Басюк Е.О., Чульчеков Д.Н., Сыроваткин Е.В. 2013. Распределение и гидрологические условия обитания минтая в северо-западной части Берингова моря в летне-осенний период // Известия ТИНРО. Т. 174 С. 104-124.

Кузнецова Н.А. 2007. Материалы по питанию молоди рыб в восточной части Берингова моря в 2003-2006 гг. // Известия ТИНРО. Т. 150. С. 226-247.

Кулик В.В. 2007. Многолетняя динамика относительного обилия нектона и макропланктона в верхних слоях пелагиали Охотского моря // Известия ТИНРО. Т. 150. С. 56-85.

Кулик В.В. 2009. Динамика обилия рыб и беспозвоночных в пелагиали Охотского моря в связи с гелиофизическими и климато-океанологическими факторами: Автореф. дисс. ... канд. биол. наук. Владивосток: ТИНРО. 24 с.

Кушинг Д.Х. 1979. Морская экология и рыболовство. М.: Пищевая пром-сть. 288 с.

Лобода С.В., Жигалин А.Ю. 2017. Результаты исследований тихоокеанской сельди в северо-западной части Берингова моря в 2010-2015 гг. // Известия ТИНРО. Т. 188. С. 125139.

Лукьянова О.Н., Борисенко Г.С., Журавель Е.В., Черкашин С.А., Черняев А.П., Цыганков В.Ю. 2018. Экологическое состояние дальневосточных морей // Загрязнение морской среды: экологический мониторинг, биоиндикация, нормирование. Сб. статей Всерос. науч. конф. с междунар. участием, посвящ. 125-летию профессора В.А. Водяницкого, Севастополь, 28 мая - 1 июня 2018 г. Севастополь: «Колорит». С. 135-142.

Лучин В.А. 2008. Термический режим вод дальневосточных морей (Японского, Охотского, Берингова): Автореф. дисс. ... док. геогр. наук. Владивосток: ТОИ РАН. 48 с.

Макоедов А.Н., Коротаев Ю.А., Антонов Н.П. 2009. Азиатская кета. Петропавловск-Камчатский: КамчатНИРО. 356 с.

Макрофауна пелагиали западной части Берингова моря: таблицы встречаемости, численности и биомассы, 19822009 гг. 2012. Владивосток: ТИНРО-Центр. 479 с.
Максименков В.В. 2002. Питание и пищевые отношения молоди рыб, обитающих в эстуариях рек и прибрежье Камчатки: Автореф. дисс. ... докт. биол. наук. Владивосток: ТИНРО. $42 \mathrm{c}$.

Малоземов О.Ю. 2016. Биоритмология. Екатеринбург: УглтУ. $144 \mathrm{c}$

Мельников И.В. 1996. Молодь южного одноперого терпуга Pleurogrammus azonus в эпипелагиали глубоководных районов дальневосточных морей. 1. Японское море // Вопросы ихтиологии. Т. 36, № 4. С. 463-469.

Моисеев П.А. 1953. Треска и камбалы дальневосточных морей // Известия ТИНРО. Т. 40.287 с.

Мухачева В.А., Звягина О.А. 1960. Развитие тихоокеанской трески Gadus morhua macrocephalus Tilesius // Тр. ИОАН CCCP. T. 31. C. 145-165.

Напазаков В.В. 2003. Питание и пищевые отношения рыб донных ихтиоценов западной части Берингова моря: Автореф. дисс. ... канд. биол. наук. Владивосток: ДВГУ. 23 с.

Науменко Н.И. 2001. Биология и промысел морских сельдей Дальнего Востока: Монография. Петропавловск-Камчатский: Камчатский печатный двор. 330 с.

Николаев А.В., Степаненко М.А. 2001. Состояние ресурсов, особенности распределения восточноберинговоморской популяции минтая (Theragra chalcogramma) по результатам акустической съёмки летом 1999 г. // Известия ТИНРО. Т. 128. С. 188-206.

Никольский Г.В. 2012. Теория динамики стада рыб как биологическая основа рациональной эксплуатации и воспроизводства рыбных ресурсов. Избранные труды, новое издание. Т. 1. М.: Изд-во ВНИРО. 465 с.

Новикова О.В. 2007. Дальневосточная навага (Eleginus gracilis (Til.)) прикамчатских вод: Автореф. дисс. ... канд. биол. наук. Петропавловск-Камчатский: КамчатНИРО. 23 с.

Новикова О.В. 2014. Обзор промысла тихоокеанской наваги Eleginus gracilis (Til.) в дальневосточных морях // Исследования водных биологических ресурсов Камчатки и северо-западной части Тихого океана. Вып. 33. С. 38-48.

Нуждин В.А. 1987. Распределение икры и личинок минтая в северо-западной части Японского моря // Популяционная структура, динамика численности и экология минтая. Владивосток: ТИНРО. С. 74-80.

Нуждин В.А. 2008. Биология и состояние запасов минтая Theragra chalcogramma в водах Приморья: Автореф. дисс. ... канд. биол. наук. Владивосток: ТИНРО-центр. 20 с.

Овсянников Е.E. 2011. Динамика пространственного распределения икры и молоди минтая в северной части Охотского моря: Автореф. дисс. ... канд. биол. наук. Владивосток: ТИНРО-Центр. 20 с.

Островский В.И. 2011. Факторы, определяющие численность покатной молоди горбуши (Oncorhynchus gorbuscha) p. Иска // Известия ТИНРО. Т. 166. С. 88-102.

Островский В.И. 2014. Факторы, определяющие численность покатной молоди горбуши (Oncorhynchus gorbuscha) p. Мы // Известия ТИНРО. Т. 177. С. 156-166.

Охотоморский минтай - 2018 (путинный прогноз). 2017. Владивосток: ТИНРО-Центр, 76 с.

Патин С.А. 2008. Нефтяные разливы и их воздействие на морскую среду и биоресурсы. М.: Изд-во ВНИРО. 508 с. 
Перцева-Остроумова Т.А. 1961. Размножение и развитие дальневосточных камбал. М.: АН СССР. 484 с.

Перцева-Остроумова Т.А. 1962. Особенности размножения и развития камбал, имеющих донные и пелагические икринки // Вопросы ихтиологии. Т. 5. С. 161-163.

Пищальник В.М., Минервин И.Г., Трусков П.А. 2020. Оценка объёма льда Охотского моря по его возрастным характеристикам за период 2001-2019 гг. // Известия ТИНРО. Т. 200, вып. 2. С. 427-444.

Пищальник В.М., Романюк В.А., Минервин И.Г., Батухтина А.С. 2016. Анализ динамики аномалий ледовитости Охотского моря в период с 1882 по 2015 гг. // Известия ТИНРО. Т. 185. С. $158-171$.

Плотников В.В., Вакульская Н.М. 2012. Изменчивость ледовых условий Берингова моря во второй половине $X X$ - начале XXI века // Известия ТИНРО. Т. 170. С. 220-228.

Плотников В.В., Вакульская Н.М., Дубина В.А. 2019. Изменчивость ледовых условий Берингова моря // Океанология. Т. 59, № 6. С. 920-927.

Полтев Ю.Н., Мухаметов И.Н., Фатыхов Р.Н. 2012. О нересте тихоокеанской трески Gadus macrocephallus в водах к юго-востоку от острова Онекотан // Вопросы ихтиологии. Т. 52, № 6. С. 734-738.

Полутов В.И. 1991. Темп полового созревания и плодовитость палтусовидной камбалы у восточного побережья Камчатки // Исследование биологии и динамики численности промысловых рыб камчатского шельфа. Вып. 1, ч. 2. Петропавловск-Камчатский: КамчатНИРО. С. 16-22.

Пушников В.В. 1978. Пространственная структура минтая Охотского моря // Известия ТИНРО. Т. 102. С. 90-96.

Пушников В.В. 1982. Популяционная структура минтая Охотского моря и состояние его запасов: Автореф. дисс. ... канд. биол. наук. Владивосток. 23 с.

Радченко В.И. 2015. Характеристика экосистемы Охотского моря по результатам моделирования // Труды ВНИРО. T. 155. С. 79-111.

Ростов И.Д., Рудых Н.И., Ростов В.И., Воронцов А.А. 2016. Тенденции климатических и антропогенных изменений морской среды прибрежных районов России в Японском море за последние десятилетия // Известия ТИНРО. Т. 186. C. $163-181$.

Савин А.Б. 2013. Распределение и миграции тихоокеанской трески в западной части Берингова моря, у побережья восточной Камчатки и в Охотском море // Тихоокеанская треска дальневосточных вод России / под ред. Орлова А.М. М: Изд-во ВНИРО. С. 37-80.

Сафронов С.Н. 1986. Тихоокеанская навага // Биологические ресурсы Тихого океана. М.: Наука. С. 201-212.

Свирский В.Г., Иванов П.П. 1984. Выедание личинок сайры дальневосточной сардиной // Биология моря. № 4. С. 6790.

Серобаба И.И. 1968. Нерест минтая в северо-восточной части Берингова моря // Вопросы ихтиологии. Т. 8, вып. 6. С. 992-1003.

Серобаба И.И. 1974. Экология нереста беринговоморского минтая // Вопросы ихтиологии. Т. 14, вып. 4. С. 635-648.

Смирнов А.А. 2014. Биология, распределение и состояние запасов гижигинско-камчатской сельди: Монография. Магадан: СВГУ. 170 с.
Cтепаненко М.A. 2001 а. Состояние запасов, межгодовая изменчивость численности пополнения и промысловое использование минтая восточноберинговоморской популяции в 80-90-е годы // Известия ТИНРО. Т. 128. С. 145-152.

Степаненко М.A. 2001 б. Закономерности межгодовой изменчивости численности восточноберинговоморской популяции минтая Theragra chalcogramma и её тенденции в конце 90-х годов // Известия ТИНРО.Т. 128. С. 136-144.

Степаненко М.А., Грицай Е.В. 2016. Состояние ресурсов, пространственная дифференциация и воспроизводство минтая в северной и восточной частях Берингова моря // Известия ТИНРО. Т. 185. С. 16-30.

Степаненко М.А., Николаев А.В. 2005. Состояние ресурсов восточноберинговоморского минтая (Theragra chalcogramma) в начале 2000-х годов и управление его рыболовством // Вопросы рыболовства. Т. 6, № 2. С. 326-345.

Тарасюк С.Н. 1997. Биология и динамика численности основных промысловых камбал Сахалина: Автореф. дисс. ... канд. биол. наук. Владивосток. 24 с.

Токранов А.М., Винников А.В. 1991. Особенности питания тихоокеанской трески и её место в трофической системе прибрежных вод Камчатки // Вопросы ихтиологии. Т. 31. C. 253-265.

Трофимов И.К. 2010. О распределении наваги Eleginus gracilis на шельфе Карагинского и Олюторского заливов Берингова моря (по материалам донных траловых съемок 1971-2006 гг.) // Исследования водных биологических ресурсов Камчатки и северо-западной части Тихого океана. Вып. 18. С. 58-70.

Фадеев Н.С. 1971. Биология и промысел тихоокеанских камбал. Владивосток: Дальиздат. 100 с.

Фадеев Н.С. 1981. Сроки размножения и нерестовых подходов минтая // Экология, запасы и промысел минтая. Владивосток: ТИНРО. С. 3-18.

Фадеев Н.С. 1986. Берингово море // Биологические ресурсы Тихого океана. М.: Наука. С. 389-405.

Фадеев Н.С. 1987. Нерестилища и сроки размножения минтая северной части Охотского моря // Популяционная структура, динамика численности и экология минтая. Владивосток: ТИНРО. С. 5-22.

Фадеев Н.С. 1988. Распределение и миграции минтая в Беринговом море // Рыбное хозяйство. № 7. С. 46-47

Фадеев Н.С. 2005. Справочник по биологии и промыслу рыб северной части Тихого океана. Владивосток: ТИНРО-Центр. 366 с.

Фадеев Н.С. 2009. Минтай Японского моря. Сроки и районы нереста, популяционный состав // Известия ТИНРО. Т. 159. C. 70-100.

Фадеев Н.С., Веспестад В. 2001. Обзор промысла минтая // Известия ТИНРО. Т. 128. С. 75-91.

Фадеев Н.С., Смирнов А.В. 1987. Оценка численности икры и производителей минтая в северной части Охотского моря // Биология моря. № 4. С. 19-25.

Фархутдинов Р.К. 2005. Экология воспроизводства, динамика численности и состояние запасов охотской сельди: Автореф. дисс. ... канд. биол. наук. Хабаровск: ВНИИПРХ. 22 с.

Фельдман М.Г., Шевляков Е.А. 2015. Выживаемость камчатской горбуши как результат совокупного воздействия плот- 
ностной регуляции и внешних факторов среды // Известия ТИНРО. Т. 182. С. 88-114.

Фигуркин А.Л., Жигалов И.А., Ванин Н.С. 2008. Океанологические условия в Охотском море в начале 2000-х гг. // Известия ТИНРО. Т. 152. С. 240-252.

Хен Г.В., Басюк Е.О., Зуенко Ю.И., Устинова Е.И., Фигуркин А.Л., Глебова С.Ю., Шатилина Т.А. 2009. Особенности гидрологических условий в дальневосточных морях в 20082009 гг. // Вопросы промысловой океанологии. Вып. 6, № 2. C. $22-47$.

Хен Г.В., Басюк Е.О., Сорокин Ю.Д., Устинова Е.И., Фигуркин А.Л. 2008. Термические условия на поверхности Берингова и Охотского морей в начале 21-го века на фоне полувековой изменчивости // Известия ТИНРО. Т. 153. С. 254263.

Чернявский Ф.Б. 1984. Млекопитающие крайнего северо-востока Сибири. М.: Наука. 388 с.

Чернявский Ф.Б. 2007. Исследования популяционных циклов леммингов и лесных полёвок в восточном секторе Субарктики // Вестник СВНЦ ДВО РАН. Вып 3. С. 28-33.

Четвергов А.В. 2002. Половое созревание западнокамчатских камбал // Известия ТИНРО. Т. 130, ч. 3. С. 940-953.

Чучукало В.И. 2006. Питание и пищевые отношения нектона и нектобентоса в дальневосточных морях. Владивосток: ТИНРО-Центр. 484 с.

Швари С.С. 1969. Эволюционная экология животных: экологические механизмы эволюционного процесса. Свердловск. 197 c.

Шевченко В.В., Датский А.В. 2014. Биоэкономика использования промысловых ресурсов минтая Северной Пацифики. Опыт российских и американских рыбопромышленников. М.: ВНИРО. 212 с.

Шунтов В.П. 2001. Биология дальневосточных морей России. Владивосток: ТИНРО-центр. Т. 1.580 с.

Шунтов В.П. 2016. Биология дальневосточных морей России. Владивосток: ТИНРО. Т. 2. 604 с.

Шунтов В.П., Волков А.Ф., Темных О.С., Дулепова Е.П. 1993. Минтай в экосистемах дальневосточных морей. Владивосток: ТИНРО. 426 с.

Шунтов В.П., Иванов О.А. 2019. Климатические изменения и современное состояние биоты российских вод дальневосточных морей // Известия ТИНРО. Т. 197. С. 83-107.

Шунтов В.П., Иванов О.А. 2021. «Неверная рыба» или неверные гипотезы: что происходит с нектоном прикурильских океанических вод? // Известия ТИНРО. Т. 201. Вып. 1. C. 3-23.

Шунтов В.П., Темных О.С. 2008. Тихоокеанские лососи В морских и океанических экосистемах. Владивосток: ТИНРО-Центр. Т. 1.481 с.

Шунтов В.П., Темных О.С. 2011. Тихоокеанские лососи В морских и океанических экосистемах. Владивосток: ТИНРО-Центр. Т. 2.473 с.

Язев С.А., Леви К.Г., Задонина Н.В. 2009. Глобальное потепление и вопросы научной методологии // Известия Иркутского ун-та. Серия «Науки о Земле». Т. 1, № 1. С. 198-213.

Albanese D., Filosi M., Visintainer R., Riccadonna S., Jurman G., Furlanello C. 2012. Minerva and minepy: a $C$ engine for the MINE suite and its R, Python and MATLAB wrappers // Bioinformatics. V. 29, Is. 3. Pp. 406-407.
Datsky A.V., Kulik V.V., Datskaya S.A. 2021. Maximal information coefficients between some abiotic factors and fish stocks in the north-west Pacific, Mendeley Data, v4, doi: 10.17632/ d5hy9smz5p.4. Accessible via: https://data.mendeley.com/ datasets/d5hy9smz5p/4.

Hastie T., Tibshirani R. 1990. Generalized Additive Models. London: Chapman \& Hall. 467 p.

Hinckley S. 1987. The reproductive biology of walleye pollock, Theragra chalcogramma, in the Bering Sea, with reference to spawning stock structure // Fish. Bull. V. 85, № 3, pp. 481-498.

lanelli J.N., Honkalehto T., Barbeaux S., Kotwicki S., Aydin K. Williamson N. 2013. Assessment of the walleye pollock stock in the Eastern Bering Sea. Accessible via: http://www. afsc.noaa.gov/REFM/docs/2013/EBSpollock.pdf.

Ianelli J.N., Kotwicki S., Honkalehto T., McCarthy A., Stienessen S., Holsman K. 2018. Chapter 1: Assessment of the walleye pollock stock in the Easter Bering Sea. Accessible via: https://www.afsc.noaa.gov/REFM/docs/2018/ BSAl/2018EBSpollock.pdf.

Kinney J.B., Atwal G.S. 2014. Equitability, mutual information, and the maximal information coefficient // Proc. Natl. Acad. Sci. USA. 111(9): 3354-3359.

Large S.I, Fay G., Friedland K.D., Link J.S. 2015. Critical points in ecosystem responses to fishing and environmental pressures // Mar. Ecol. Prog. Ser. V. 521. Pp. 1-17.

McArthur R.H., Wilson E.O. 1967. The theory of island biogeography. Princeton (N.J.): Princeton Univ. Press. 203 p.

NPAFC. Доступно через: http://www.npafc.org/new/science statistics.html. 09.09.2021.

Okada K. 1986. Biological characteristics and abundance of pelagic pollock in the Aleutian Basin // Bull. INPFC. № 45. Pp. 150-176.

Ormseth O.A. 2019. Status of forage species in the Bering Sea and Aleutian Islands region // Alaska Fisheries Science Center. Pp. 1-46. Accessible via: https://apps-afsc.fisheries. noaa.gov/refm/docs/2019/BSAlforage.pdf.

Reshef D. N. Reshef Y.A., Mitzenmacher M., Sabeti P.C. 2014. Cleaning up the record on the maximal information coefficient and equitability // Proc. Natl. Acad. Sci. V. 111, № 33. Pp. 3362-3363.

Reshef D.N., Reshef Y.A., Finucane H.K., Grossman S.R., McVean G., Turnbaugh P.J., Lander E.S., Mitzenmacher M., Sabeti P.C. 2011. Detecting novel associations in large data sets // Science. V. 334, № 6062, pp. 1518-1524.

Sakamoto Y., Ishiguro M., Kitagawa G. 1986. Akaike Information Criterion Statistics. D. Reidel Publishing Company. Tokyo, Dordrecht etc. 290 p.

Siddon E., Zador S. 2017. Status of the Eastern Bering Sea Marine Ecosystem. Ecosystem Considerations 2017 // North Pacific Fishery Management Council. Anchorage, AK. pp. 1-229. Accessible via: https://www.afsc.noaa.gov/REFM/ Docs/2017/ecosysEBS.pdf.

Stepanenko M.A. 1989. The state of stocks and distribution of pollock in the Bering Sea // Proc. Intern. Symp. Biol. Managem. Walleye Pollock, Nov. 1988. Fairbanks, Alaska. Pp. 537-547.

Vasilets P.M. 2015. FMS analyst - computer program for processing data from Russian Fishery Monitoring System. doi:10.13140/RG.2.1.5186.0962. 
Vinnikov A.V. 1996. Pacific cod (Gadus macrocephalus) of the Western Bering Sea // Ecology of Bering Sea: a review of Russian literature (Mathisen O.A., Coyle K.O., eds.). Alaska Sea Grant Report № 96-01. Fairbanks: University of Alaska. Pp. 183-202.

Wood S.N. 2003. Thin plate regression splines // J.R. Stat. Soc. Ser. B (Statistical Methodol). V. 65, № 1, pp. 95-114.

Wood S.N. 2011. Fast stable restricted maximum likelihood and marginal likelihood estimation of semiparametric generalized linear models // J.R. Stat. Soc. Ser. B (Statistical Methodol). V. 73, № 1, pp. 3-36.

Wood S.N., Shaw S., Goude Y. 2015. Generalized additive models for large data sets // J.R. Stat. Soc. Ser. C (Applied Stat.). V. 64, № 1, pp. 139-155.

\section{REFERENCES}

Abdusamatov Kh.I. 2012. A two-century decrease in the solar constant leads to an unbalanced thermal budget of the Earth and a deep cooling of the climate // Kinematics and Physics of Celestial Bodies. V. 28, № 2. P. 22-33. (In Russ.).

Antonov N.P.1991. Biology and population dynamics of the East Kamchatka pollock: Author's abstract. diss. ... cand. biol. sciences. Vladivostok: TINRO. 23 p. (In Russ.).

Antonov N.P. 2011. Commercial fish of the Kamchatka territory: biology, stocks, fishing. M.: VNIRO. 244 p. (In Russ.).

Antonov N.P. 2013. Cod Gadus macrocephalus of the Kamchatka waters // Pacific cod of the Far Eastern waters of Russia / Ed. A.M. Orlov. M.: VNIRO Publishing house. P. 133-151. (In Russ.).

Antonov N.P., Datsky A.V. 2019. Use of the raw material base of marine fish in the Far Eastern fishery basin in 2018 // Fisheries. № 3. P. 66-76. (In Russ.).

Antonov N.P., Datsky A.V., Maznikova O.A., Mitenkova L.V. 2016. The current state of the Pacific herring fishery in the Far Eastern seas // Fish industry. № 1. P. 54-58. (In Russ.).

Antonov N.P., Zolotov O.G. 1987. Peculiarities of reproduction of the East Kamchatka pollock // Population structure, population dynamics and ecology of Alaska pollock. Vladivostok: TINRO. P. 123-132. (In Russ.).

Antonov N.P., Kuznetsova E.N. 2018. The current state of the use of the raw material base of the Far Eastern flounder // Fish industry. № 5. P. 56-61. (In Russ.).

Atlas of distribution in the sea of various stocks of Pacific salmon during spring-summer feeding and pre-spawning migrations. 2002. M.: VNIRO. 190 p. (In Russ.).

Babayan V.K. 2000. A precautionary approach to estimating total allowable catch (TAC). Analysis and recommendations for use. M.: Publishing house VNIRO. 190 p. (In Russ.).

Babayan V.K., Vasiliev D.A., Varkentin A.I., Sergeeva N.P. 2006. Methodological features of substantiating the TAC for pollock in conditions of uncertainty // Trudy VNIRO. V. 146. P. 13 -37. (In Russ.).

Balykin P.A. 1993. Variation in the timing of spawning and mortality of developing eggs in the West Bering Sea pollock (Theragra chalcogramma (Pallas)) // Study of the biology and dynamics of the number of commercial fish on the Kamchatka shelf. Is. 2. Petropavlovsk-Kamchatsky: KOTINRO. P. 166-176. (In Russ.).
Balykin P.A. 2006. Ichthyocenes of the western part of the Bering Sea: composition, commercial significance and state of stocks: Author's abstract. diss. ... doct. biol. sciences. M.: VNIRO. 50 p. (In Russ.).

Balykin P.A., Varkentin A.I. 2002. Distribution of eggs, larvae and underyearlings of pollock Theragra chalcogramma (Gadidae) in the northwestern part of the Bering Sea // Voprosy ichthyology. V. 42, № 6. P. 798-805. (In Russ.).

Balykin P.A., Zolotov A.O. 2010. Interspecific relations of aquatic organisms as a factor of population dynamics // Studies of aquatic biological resources of Kamchatka and the northwestern part of the Pacific Ocean. Is. 17. P. 24-29. (In Russ.).

Bering Sea Alaska pollock fishery time. 2017 (Fishery time's forecast). 2017. Vladivostok: TINRO-Center. 71 p. (In Russ.).

Borets L.A. 1997. Bottom ichthyocenes of the Russian shelf of the Far Eastern seas: composition, structure, functioning elements and commercial significance. Vladivostok: TINROCenter. 217 p. (In Russ.).

Borets L.A., Stepanenko M.A., Nikolaev A.V., Gritsay E.V. 2002. The state of pollock stocks in the Navarinsky district of the Bering Sea and the reasons determining the effectiveness of its fishing // Izvestiya TINRO. V. 130, part III. P. 10011014. (In Russ.).

Breus T.K. 2003. Influence of solar activity on biological objects: Author's abstract. diss. ... doct. phys.-mat. sciences. M.: IKI RAN. 32 p. (In Russ.).

Bugaev V.F. 2011. Asiatic sockeye salmon-2 (biological structure and dynamics of the number of local herds in the late XX - early XXI centuries). Petropavlovsk-Kamchatsky: Kamchatpress Publishing House. 380 p. (In Russ.).

Bugaev V.F., Vronsky B.B., Zavarina L.O., Zorbidi Zh. Kh., Ostroumov A.G., Tiller I.V. 2007. Fish of the Kamchatka river. Petropavlovsk-Kamchatsky: KamchatNIRO Publishing House. 459 p. (In Russ.).

Bulatov O.A. 1986. Distribution of eggs and larvae of cod (subfamily Gadinae) in the Pacific waters of Kamchatka and the western part of the Bering Sea // Far Eastern Codfish. Vladivostok: TINRO. P. 89-102. (In Russ.).

Bulatov O.A. 1987. Pollock roe and larvae in the eastern part of the Bering Sea // Population structure, population dynamics and ecology of pollock. Vladivostok: TINRO. P. 100-114. (In Russ.).

Bulatov O.A. 2004. Pollock (Theragra chalcogramma) of the Bering Sea: reproduction, stocks and fishery management strategy: Author's abstract. diss. ... doct. biol. sciences. M.: VNIRO. 49 p. (In Russ.).

Bulatov O.A. 2014. Pollock fishery and stocks: is turbulence possible? // Voprosy rybolovstva. V. 15, № 4. P. 350-390. (In Russ.).

Bulatov O.A. 2017. Vertical distribution of pollock roe and larvae // Voprosy rybolovstva. V. 18, № 3. P. 269-285. (In Russ.).

Buslov A.V. 2001. New data on the distribution and migrations of pollock in the Pacific waters of the northern Kuril Islands and southeastern Kamchatka // Izvestia TINRO. V. 128. P. 229-241. (In Russ.).

Buslov A.V. 2008. Pollock on the eastern coast of Kamchatka: current state of reserves and recommendations for rational exploitation // Izvestiya TINRO. V. 152. P. 3-17. (In Russ.). 
Buslov A.V., Tepnin O.B. 2002. Conditions for spawning and embryogenesis of pollock Theragra chalcogramma (Gadidae) in the deep-water canyons of the Pacific coast of Kamchatka // Voprosy ichthyologii. V. 42, № 5. P. 617-625. (In Russ.).

Buslov A.V., Tepnin O.B., Dubinina A. Yu. 2004. Some features of the spawning ecology and embryogenesis of the Eastern Kamchatka pollock // Izvestia TINRO. V. 138. P. 282-298. (In Russ.).

Varkentin A.I. 2015. New data on the timing of mass spawning of pollock (Theragra chalcogramma) in Western Kamchatka // Studies of aquatic biological resources of Kamchatka and the northwestern Pacific Ocean. Is. 39. P. 70-74. (In Russ.).

Vdovin A.N., Chetlebotsky A.N., Nuzhdin V.V. 2017. Dynamics of the number of the seaside pollock Theragra chalcogramma (Pallas, 1814) (Gadiformes: Gadidae) in the Sea of Japan // Marine Biology. V. 43, № 5. P. 321-328. (In Russ.).

Vershinin V.G. 1984. Biology and fishing of cod in the Northwestern Pacific Ocean: Author's abstract. diss. ... cand. biol. sciences. Vladivostok: DVNTS AS USSR. 21 p. (In Russ.).

Vershinin V.G. 1987. About biology and the current state of cod stocks in the northern part of the Bering Sea // Biological resources of the Arctic and Antarctic. M.: Nauka. P. 207-224. (In Russ.).

Vinnikov A.V. 2008. Pacific cod of Western Kamchatka: biology, population dynamics, fishing: Author's abstract. diss.... cand. biol. sciences. Vladivostok: IBM FEB RAS. 24 p. (In Russ.).

Volvenko I.V. 2014. Comparison of the Far Eastern seas and the Northwestern Pacific Ocean by integral characteristics of the trawl macrofauna of pelagial and bottom // Izvestia TINRO. V. 178. P. 58-67. (In Russ.).

Volkov A.F. 2014. The state of the feeding base of Pacific salmon in the Bering Sea in 2003-2012 (based on the results of the international expeditions BASIS-1 and 2) // Izvestiya TINRO. V. 179. P. 250-271. (In Russ.).

Vyshegorodtsev V.A. 1987. On the Is. of reproductive isolation of the North Okhotsk pollock population // Population composition, population dynamics and ecology of pollock. Vladivostok: TINRO. P. 39-47. (In Russ.).

Glubokov A.I., Alekseev D. O., Bizikov V.A. 2000. On the cannibalism of pollock in the north-western part of the Bering Sea at the end of the 90s // Voprosy rybolovstva. V.1, № 4. P. 91-97. (In Russ.).

Gorbatenko K.M. 2018. Trophodynamics of hydrobionts in the Sea of Okhotsk: Author's abstract. diss. ... doct. biol. sciences. Vladivostok: TINRO. 47 p. (In Russ.).

Gorbunova N.N. 1954. Reproduction and development of pollock // Trudy IO AS USSR. V.11. P. 132-195. (In Russ.).

Gorbunova N.N. 1959. On the reproduction of the southern one-legged terpug // Izvestiya TINRO. V. 47. P. 145-153. (In Russ.).

Gritsay E.V. 2006. Variability of the size-age composition of Alaska pollock on the East and North Bering Sea shelf // Izvestiya TINRO. T. 146. S. 84-102. (In Russ.).

Gritsay E.V., Sheibak A.Yu. 2009. Analysis of the fishery and dynamics of the size-age composition of pollock in the Anadyr-Navarinsky region in 2003-2008 // Izvestiya TINRO. T. 158. S. 158-186. (In Russ.).

Gudkovich Z.M., Karklin V.P., Mironov E. Yu., Ivanov V. V., Losev S.M., Dyment L.N., Smolyanitsky V.M., Frolov S. V.,
Yulin A.V., Usoltseva E.A. 2013. The development of ice and meteorological conditions in the Arctic in the period 20072013 // Problems of the Arctic and Antarctica. № 2 (96). P. 90-102. (In Russ.).

Datsky A.V. 2004. Reproduction of pollock Theragra chalcogramma (Gadidae) in the Anadyr Bay // Voprosy rybolovstva. V. 5, № 4(20). P. 597-617. (In Russ.).

Datsky A. V., Andronov P. Yu. 2007. Ichthyocene of the upper shelf of the northwestern part of the Bering Sea. Magadan: SVNTS FEB RAS. 261 p. (In Russ.).

Dementieva T.F. 1961. The importance of the decisive factor in the light of annual and long-term fluctuations in the number of populations. Proceedings of the meeting on the dynamics of the number of fish. M.: RAS Publishing House. Is. 13. P. 34-43. (In Russ.).

Dynamics of ecosystems of the Bering and Chukchi Seas. 2000. M.: Nauka. 357 p. (In Russ.).

Dudnik Yu.I., Zolotov O.G. 2000. Distribution, features of biology and fishing of one-finned greenplants of the genus Pleurogrammus (Hexagrammidae) in the waters near the Kuril Islands // Commercial and biological studies of fish in the Pacific waters of the Kuril Islands and adjacent areas of the Okhotsk and Bering Seas in 1992-1998. M.: VNIRO Publishing House. P. 78-90. (In Russ.).

Dumanskaya I.O. 2017. Ice conditions of the seas of the Asian part of Russia. M.; Obninsk: IG-SOCIN. 640 p. (In Russ.).

Dyakov B.S. 2010. Regularities of the development of hydrometeorological conditions of the Sea of Japan in 1950-2009 and the forecast of water temperature // Voprosy promyslovoj okeanologii. Is. 7. № 2. P. 102-108. (In Russ.).

Dyakov Yu.P. 2011. Flatfish (Pleuronectiformes) of the Far Eastern seas of Russia (spatial organization of fauna, seasons and duration of spawning, population structure of the species, population dynamics). PetropavlovskKamchatsky: KamchatNIRO Publish. 433 p. (In Russ.).

Zherebtsov G.A., Kovalenko V.A., Molodykh S.I., Kirichenko K.E. 2013. The influence of solar activity on the temperature of the troposphere and the ocean surface // News of the Irkutsk State University. Series “Earth Sciences”. V. 6, № 1. P. 61-79. (In Russ.).

Zverkova L.M. 1969. About pollock spawning in the waters of the western coast of Kamchatka // Voprosy ikhtiologii. V. 9, Is. 2. P. 270-275. (In Russ.).

Zverkova L.M.1971. Pollock breeding off the southwestern coast of Sakhalin // Izvestia TINRO. V. 76. P. 62-75. (In Russ.).

Zverkova L.M. 1977. Maturation, fertility and breeding areas of pollock Theragra chalcogramma (Pallas) in the northeastern part of the Sea of Japan // Voprosy ikhtiologii. V. 17, Is. 3. P. 462-468. (In Russ.).

Zverkova L.M. 1981. Intraspecific structure of pollock in the Sea of Okhotsk // Ecology, stocks and fishing of pollock. Vladivostok: TINRO. P. 41-56. (In Russ.).

Zverkova L.M. 1987. Spatial and temporal structure of the pollock reproduction area Theragra chalcogramma (Gadidae) in the northern part of the Sea of Okhotsk // Voprosy ikhtiologii. V. 27, Is. 3. P. 414-420. (In Russ.).

Zverkova L.M., Pushnikov V.V. 1980. Distribution of pelagic pollock caviar in the Sea of Okhotsk // Fishery studies of 
temperate waters of the Pacific Ocean. Vladivostok. P. 117123. (In Russ.).

Zolotov A. O. 2008. The use of trawl surveys to estimate the number of flounders in the Karaginsky and Olyutorsky bays: methodology and results // Studies of aquatic biological resources of Kamchatka and the northwestern Pacific Ocean. V. 13. P. 51-58. (In Russ.).

Zolotov A.O. 2009. Modeling of the optimal fishing regime for yellowfin sole of the western part of the Bering Sea // Studies of aquatic biological resources of Kamchatka and the northwestern Pacific Ocean. Is. 11. P. 100-104. (In Russ.).

Zolotov A.O. 2011. Distribution and seasonal migrations of flounders of the Karaginsky and Olyutorsky gulfs // Studies of aquatic biological resources of Kamchatka and the north-western part of the Pacific Ocean. Is. 21. P. 73-100. (In Russ.).

Zolotov A.O., Zolotov O.G., Spirin I. Yu. 2015. The long-term dynamics of biomass and the modern fishery for Atka mackerel in the Pacific waters of Kamchatka and the Kuril Islands // Izvestiya TINRO. V. 181. P. 3-22. (In Russ.).

Zolotov A.O., Smirnov A.V., Baranchuk-Chervonny L.N., Dubinina A. Yu. 2014. Long-term dynamics and current state of the stock of yellowfin sole in the waters of Sakhalin Island // Izvestiya TINRO. V. 178. P. 25-57. (In Russ.).

Zolotov A.O., Terentyev D.A., Spirin I. Yu. 2013. The composition and current state of the demersal fish community of the Karaginsky and Olyutorsky bays // Izvestiya TINRO. V. 174. P. 85-103. (In Russ.).

Zolotov A. O., Fatykhov R.N. 2016. Status of stocks and fishing features Okhotsk atka mackerel Jordan et Metz (1913) in the waters of the southern Kuril Islands // Izvestiya TINRO. V. 186. P. 61-80. (In Russ.).

Zolotov O.G. 1975. Distribution of the Atka mackerel in the coastal waters of the northern Kuril Islands // Izvestiya TINRO. V. 97. P. 37-43. (In Russ.).

Zolotov O.G. 1981. Sexual dimorphism in the Atka mackerel Pleurogrammus monopterigius // Voprosy ikhtiologii. V. 21, Is. 2. P. 253-257. (In Russ.).

Zolotov O.G. 1991. Distribution and drift of pollock eggs and larvae off the western coast of Kamchatka // Investigation of biology and population dynamics of commercial fish of the Kamchatka shelf. Is. 1, part 1. PetropavlovskKamchatsky: KamchatNIRO. P. 167-182. (In Russ.).

Zolotov O.G., Orlov A.M. 2009. The role of submarine uplifts in the structure of the range of the Atka mackerel // Fisheries. V. 6. P. 53-56. (In Russ.).

Zorbidi J.H. 2010. Coho salmon Asian stud. PetropavlovskKamchatsky: KamchatNIRO, 306 p.

Izhevsky G.K. 1961. Oceanological foundations of the formation of commercial productivity of the seas: Monograph. M.: Food. prom. 216 p. (In Russ.).

Izhevsky G.K. 1964. The system basis for forecasting oceanological conditions of fish reproduction. M.: VNIRO. 165 p. (In Russ.).

Ilyin O.I., Sergeeva N.P., Varkentin A.I. 2014. Stock assessment and forecasting of the TAC of the East Kamchatka pollock (Theragra chalcogramma) based on a precautionary approach // Trudy VNIRO. V. 151. P. 62-74. (In Russ.).
Karpenko V.I. 1998. The early marine life of Pacific salmon. M.: VNIRO. 165 p. (In Russ.).

Kachina T.F.1981. Herring of the western part of the Bering Sea. M.: Leg. and food. prom-st. 121 p. (In Russ.).

Kachina T.F., Balykin P.A. 1981. Pollock spawning in the western part of the Bering Sea // Ecology, stocks and fishing of pollock. Vladivostok: TINRO. pp. 63-72. (In Russ.).

Kim Sen Tok, Biryukov I.A. 2009. Some features of biology and commercial resources of bottom and bottom fish species in the shelf waters of the Southern Kuril Islands in 19872006. Yuzhno-Sakhalinsk: SakhNIRO. 124 p. (In Russ.).

Kim Sen Tok. 2007. The modern structure and trends in the resources of demersal fish in the Western Sakhalin waters // Izvestiya TINRO. V. 148. P. 35-56. (In Russ.).

Kim Sen Tok. 2013. Distinctive features of the biology and resources of cod in the northeastern part of the Sea of Japan (the west coast of Sakhalin) // Pacific cod of the Far Eastern waters of Russia / edited by A.M. Orlov. M.: VNIRO. P. 81-106. (In Russ.).

Klyashtorin L.B., Lyubushin A.A. 2005. Cyclical changes in climate and fish productivity. M.: VNIRO Publishing House. 235 p. (In Russ.).

Kolesnik Yu.A. 2002 a. The unevenness of the Earth's rotation and its influence on natural processes and dynamics of biosystems // Izvestiya TINRO. T. 130. P. 1283-1297. (In Russ.).

Kolesnik Yu.A. 2002 b. Investigation of biota reactions to longterm changes in heliogeophysical processes: Author's abstract. diss. ... doct. biol. sciences. Vladivostok: DVSU. 43 p. (In Russ.).

Krovnin A.S., Antonov N.P., Kotenev B.N., Muriy G.P. 2017. The influence of climate on quasi-decadal changes in the number of generations of cod in the north-western part of the Bering Sea // Trudy VNIRO. V. 169. P. 37-50. (In Russ.).

Kuznetsov M. Yu., Basyuk E.O., Chulchekov D.N., Syrovatkin E.V. 2013. Distribution and hydrological conditions of pollock habitat in the north-western part of the Bering Sea in the summer-autumn period // Izvestiya TINRO. V. 174. P. 104124. (In Russ.).

Kuznetsova N.A. 2007. Materials on the nutrition of juvenile fish in the eastern part of the Bering Sea in 2003-2006 // Izvestiya TINRO. V. 150. P. 226-247. (In Russ.).

Kulik V.V. 2007. Long-term dynamics of the relative abundance of necton and macroplankton in the upper layers of the pelagial of the Sea of Okhotsk // Izvestiya TINRO. V. 150. P. 56-85. (In Russ.).

Kulik V.V. 2009. Dynamics of abundance of fish and invertebrates in the pelagial of the Sea of Okhotsk in connection with heliophysical and climatic-oceanological factors: Author's abstract. diss. ... cand. biol. sciences. Vladivostok: TINRO. 24 p. (In Russ.).

Cushing D.H. 1979. Marine ecology and fisheries. M.: Food industry. 288 p. (In Russ.).

Loboda S. V., Zhigalin A. Yu. 2017. Results of studies of Pacific herring in the northwestern part of the Bering Sea in 2010-2015 // Izvestiya TINRO. V. 188. P. 125-139. (In Russ.).

Lukyanova O.N., Borisenko G.S., Zhuravel E.V., Cherkashin S.A., Chernyaev A.P., Tsygankov V. Yu. 2018. Ecological state of the Far Eastern seas // Marine pollution: ecological 
monitoring, bioindication, rationing. Collection of articles of the All-Russian Scientific Conference with the international participation, dedication. 125th anniversary of Professor V.A. Vodyanitsky, Sevastopol, May 28 - June 1, 2018 Sevastopol: “Color”. P. 135-142. (In Russ.).

Luchin V.A. 2008. Thermal regime of the waters of the Far Eastern seas (Japanese, Okhotsk, Bering): Author's abstract. diss. ...doc. geogr. sciences. Vladivostok: TOI RAS. 48 p. (In Russ.).

Makoedov A.N., Korotaev Yu.A., Antonov N.P. 2009. Asian chum salmon. Petropavlovsk-Kamchatsky: KamchatNIRO. 356 p. (In Russ.).

Macrofauna of the pelagial of the western part of the Bering Sea: tables of occurrence, abundance and biomass, $1982-$ 2009, 2012. Vladivostok: TINRO Center. 479 p. (In Russ.).

Maksimenkov V.V. 2002. Nutrition and nutritional relations of juvenile fish living in estuaries of rivers and the coast of Kamchatka: Author's abstract. diss. ... doct. biol. sciences. Vladivostok: TINRO. 42 p. (In Russ.).

Malozemov O. Yu. 2016. Biorhythmology. Yekaterinburg: UGLTU. 144 p. (In Russ.).

Melnikov I.V. 1996. Juveniles of the Okhotsk Atka mackerel Pleurogrammus azonus in the epipelagic zone of the deepwater regions of the Far Eastern seas. 1. Sea of Japan // Voprosy ikhtiologii. V. 36, № 4. P. 463-469. (In Russ.).

Moiseev P.A. 1953. Cod and flounders of the Far Eastern seas // Izvestia TINRO. V. 40.287 p. (In Russ.).

Mukhacheva V.A., Zvyagina O.A. 1960. The development of the Pacific cod Gadus morhua macrocephalus Tilesius // Tr. IO AS USSR. V. 31. P. 145-165. (In Russ.).

Napazakov V.V. 2003. Nutrition and food relations of fish of the bottom ichthyocenes of the western part of the Bering Sea: Author's abstract. diss. ... cand. biol. sciences. Vladivostok: DVSU. 23 p. (In Russ.).

Naumenko N.I. 2001. Biology and fishing of marine herring of the Far East: Monograph. Petropavlovsk-Kamchatsky: Kamchatka Printing Yard. 330 p. (In Russ.).

Nikolaev A.V., Stepanenko M.A. 2001. The state of resources, distribution characteristics of the East Bering Sea walleye pollock population according to the results of acoustic surveys in the summer of 1999 // Izvestiya TINRO. V. 128. P. 188-206. (In Russ.).

Nikolsky G.V. 2012. Theory of fish herd dynamics as a biological basis for rational exploitation and reproduction of fish resources. Selected works, new edition. V. 1. M.: VNIRO Publishing House. 465 p. (In Russ.).

Novikova O.V. 2007. Saffron cod in the Kamchatka waters: Author's abstract. diss. ... cand. biol. sciences. PetropavlovskKamchatsky: KamchatNIRO. 23 p. (In Russ.).

Novikova O.V. 2014. Overview of the Saffron cod fishery in the Far Eastern seas // Studies of aquatic biological resources of Kamchatka and the northwestern Pacific Ocean. Is. 33. P. 38-48. (In Russ.).

Nuzhdin V.A. 1987. Distribution of pollock eggs and larvae in the north-western part of the Sea of Japan // Population structure, population dynamics and ecology of pollock. Vladivostok: TINRO. P. 74-80. (In Russ.).

Nuzhdin V.A. 2008. Biology and state of pollock stocks Theragra chalcogramma in the waters of Primorye: Author's abstract. diss. ... cand. biol. sciences. Vladivostok: TINRO Center. 20 p. (In Russ.).

Ovsyannikov E.E. 2011. Dynamics of spatial distribution of pollock eggs and juveniles in the northern part of the Sea of Okhotsk: Author's abstract. diss. ... cand. biol. sciences. Vladivostok: TINRO Center. 20 p. (In Russ.).

Ostrovsky V.I. 2011. Factors determining the abundance of downstream juvenile pink salmon of the Iska river // Izvestia TINRO. V. 166. P. 88-102. (In Russ.).

Ostrovsky V.I. 2014. Factors determining the number of downstream juveniles of the pink salmon of the river We // Izvestia TINRO. V. 177. P. 156-166. (In Russ.).

Okhotsk Sea pollock - 2018 (Fishery time's forecast). 2017. Vladivostok: TINRO-Center, 76 p. (In Russ.).

Patin S.A. 2008. Oil spills and their impact on the marine environment and bioresources. M.: VNIRO Publish. 508 p. (In Russ.).

Pertseva-Ostroumova T.A. 1961. Reproduction and development of Far Eastern flounders. M.: AS USSR. 484 p. (In Russ.).

Pertseva-Ostroumova T.A. 1962. Features of reproduction and development of flounders with bottom and pelagic eggs // Voprosy ikhtiologii. V. 5. P. 161-163. (In Russ.).

Pischalnik V.M., Minervin I.G., Truskov P.A. 2020. Estimation of the ice volume of the Sea of Okhotsk by its age characteristics for the period 2001-2019 // Izvestiya TINRO. V. 200, Is. 2. P. 427-444. (In Russ.).

Pishchalnik V.M., Romanyuk V.A., Minervin I.G., Batukhtina A.S. 2016. Analysis of the dynamics of anomalies of the ice cover of the Sea of Okhotsk in the period from 1882 to 2015 // Izvestiya TINRO. V. 185. P. 158-171. (In Russ.).

Plotnikov V.V., Vakulskaya N.M. 2012. Variability of ice conditions of the Bering Sea in the second half of the XX - beginning of the XXI century // Izvestia TINRO. T. 170. P. 220-228. (In Russ.).

Plotnikov V.V., Vakulskaya N.M., Dubina V.A. 2019. Variability of ice conditions of the Bering Sea // Oceanology. V. 59, № 6. P. 920-927. (In Russ.).

Poltev Yu.N., Mukhametov I.N., Fatykhov R.N. 2012. About spawning of Pacific cod Gadus macrocephallus in the waters southeast of Onekotan Island // Voprosy ikhtiologii. V. 52, № 6. P. 734-738. (In Russ.).

Polutov V.I. 1991. The rate of puberty and fertility of halibut flounder off the eastern coast of Kamchatka // Study of biology and population dynamics of commercial fish of the Kamchatka shelf. Is. 1, part 2. Petropavlovsk-Kamchatsky: KamchatNIRO. P. 16-22. (In Russ.).

Pushnikov V.V. 1978. Spatial structure of pollock of the Sea of Okhotsk // Izvestiya TINRO. T. 102. P. 90-96. (In Russ.).

Pushnikov V.V. 1982. The population structure of pollock of the Sea of Okhotsk and the state of its reserves: Author's abstract. diss. ... cand. biol. sciences. Vladivostok. 23 p. (In Russ.).

Radchenko V.I. 2015. Characteristics of the ecosystem of the Sea of Okhotsk based on the results of modeling // Trudy VNIRO. V. 155. P. 79-111. (In Russ.).

Rostov I.D., Rudykh N.I., Rostov V.I., Vorontsov A.A. 2016. Trends of climatic and anthropogenic changes in the marine environment of the coastal regions of Russia in the Sea 
of Japan over the past decades // Izvestia TINRO. V. 186. P. 163-181. (In Russ.).

Savin A.B. 2013. Distribution and migration of Pacific cod in the western part of the Bering Sea, off the coast of eastern Kamchatka and in the Sea of Okhotsk // Pacific cod of the Far Eastern waters of Russia / ed. Orlov A.M. M.: VNIRO Publish. P. 37-80. (In Russ.).

Safronov S.N. 1986. Pacific navaga // Biological resources of the Pacific Ocean. M.: Nauka. P. 201-212. (In Russ.).

Svirsky V.G., Ivanov P.P. 1984. Eating larvae of saury of the Japanese pilchard // Biology of the sea. № 4. P. 67-90. (In Russ.).

Serobaba I.I.1968. Pollock spawning in the northeastern part of the Bering Sea // Voprosy ikhtiologii. V. 8, Is. 6. P. 992-1003. (In Russ.).

Serobaba I.I. 1974. Ecology of Bering Sea pollock spawning // Voprosy ikhtiologii. V. 14, Is. 4. P. 635-648. (In Russ.).

Smirnov A.A. 2014. Biology, distribution and state of stocks of the Gizhiginsko-Kamchatka herring: Monograph. Magadan: SVSU. 170 p. (In Russ.).

Stepanenko M.A. 2001 a. State of stocks, interannual variability of replenishment numbers and commercial use of walleye pollock from the East Bering Sea population in the 80-90s // Izvestiya TINRO. V. 128. P. 145-152. (In Russ.).

Stepanenko M.A. 2001 b. Patterns of interannual variability in the numbers of the East Bering Sea walleye pollock population and its trends in the late $90 \mathrm{~s} / /$ Izvestiya TINRO. V. 128. P. 136-144. (In Russ.).

Stepanenko M.A., Gritsay E.V. 2016. The state of resources, spatial differentiation and reproduction of walleye pollock in the northern and eastern parts of the Bering Sea // Izvestiya TINRO. V. 185. P. 16-30. (In Russ.).

Stepanenko M.A., Nikolaev A.V. 2005. The state of resources of the East Bering Sea walleye pollock in the early 2000s and its fisheries management // Voprosy rybolovstva. V. 6, № 2 . P. 326-345. (In Russ.).

Tarasyuk S.N. 1997. Biology and abundance dynamics of the main fishing flounders of Sakhalin: Author's abstract. diss. ... cand. biol. sciences. Vladivostok. 24 p. (In Russ.).

Tokranov A.M., Vinnikov A.V. 1991. Feeding features of Pacific cod and its place in the trophic system of Kamchatka coastal waters // Voprosy ikhtiologii. V. 31. P. 253-265. (In Russ.).

Trofimov I.K. 2010. On the distribution of Saffron cod on the shelf of the Karaginsky and Olyutorsky bays of the Bering Sea (based on the materials of bottom trawl surveys in 1971-2006) // Studies of aquatic biological resources of Kamchatka and the northwestern Pacific Ocean. Is. 18. P. 58-70. (In Russ.).

Fadeev N.S. 1971. Biology and fishery of Pacific flounders. Vladivostok: Dalizdat. 100 p. (In Russ.).

Fadeev N.S. 1981. Terms of reproduction and spawning approaches of pollock // Ecology, stocks and fishing of pollock. Vladivostok: TINRO. P. 3-18. (In Russ.).

Fadeev N.S. 1986. Bering Sea // Biological resources of the Pacific Ocean. Moscow: Nauka. P. 389-405. (In Russ.).

Fadeev N.S. 1987. Spawning grounds and breeding dates for pollock in the northern part of the Sea of Okhotsk // Population structure, population dynamics and ecology of pollock. Vladivostok: TINRO. P. 5-22. (In Russ.).
Fadeev N.S. 1988. Distribution and migration of pollock in the Bering Sea // Fisheries. № 7. P. 46-47. (In Russ.).

Fadeev N.S. 2005. Guide to the Biology and Fisheries of the North Pacific. Vladivostok: TINRO-Center. 366 p. (In Russ.).

Fadeev N.S. 2009. Pollock of the Sea of Japan. Terms and areas of spawning, population composition // Izvestiya TINRO. T. 159. P. 70-100. (In Russ.).

Fadeev N.S., Vespestad V. 2001. Walleye pollock fishing survey // Izvestia TINRO. V. 128. P. 75-91. (In Russ.).

Fadeev N.S., Smirnov A.V. 1987. Estimation of the number of caviar and pollock producers in the northern part of the Sea of Okhotsk // Biology of the sea. № 4. P. 19-25. (In Russ.).

Farkhutdinov R.K. 2005. Ecology of reproduction, dynamics of abundance and state of stocks of Okhotsk herring: Author's abstract. diss. ... cand. biol. sciences. Khabarovsk: VNIIFF. 22 p. (In Russ.).

Feldman M.G., Shevlyakov E.A. 2015. Survival of Kamchatka pink salmon as a result of the combined effect of density regulation and external environmental factors // Izvestiya TINRO. V. 182. P. 88-114. (In Russ.).

Figurkin A.L., Zhigalov I.A., Vanin N.S. 2008. Oceanological conditions in the Sea of Okhotsk in the early 2000s. // Izvestiya TINRO. V. 152. P. 240-252. (In Russ.).

Khen G.V., Basyuk E.O., Zuenko Yu.I., Ustinova E.I., Figurkin A.L., Glebova S. Yu., Shatilina T.A. 2009. Features of hydrological conditions in the Far Eastern seas in 2008-2009 // Voprosy promyslovoj okeanologii. Is. 6, № 2. P. 22-47. (In Russ.).

Hen G.V., Basyuk E.O., Sorokin Yu.D., Ustinova E.I., Figurkin A.L. 2008. Thermal conditions on the surface of the Bering and Okhotsk Seas at the beginning of the 21st century against the background of half a century of variability // Izvestiya TINRO. T. 153. P. 254-263. (In Russ.).

Chernyavsky F.B. 1984. Mammals of the extreme north-east of Siberia. M.: Nauka. 388 p. (In Russ.).

Chernyavsky F.B. 2007. Studies of population cycles of lemmings and forest voles in the eastern sector of the Subarctic // Bulletin of the SVNTS FEB RAS. Is. 3. P. 28-33. (In Russ.).

Chetvergov A.V. 2002. Sexual maturation of Western Kamchatka flounders // Izvestiya TINRO. V. 130, part 3. P. 940-953. (In Russ.).

Chuchukalo V.I. 2006. Nutrition and nutritional relationships of nekton and nectobenthos in the Far Eastern seas. Vladivostok: TINRO-Center. 484 p. (In Russ.).

Schwartz S.S. 1969. Evolutionary ecology of animals: ecological mechanisms of the evolutionary process. Sverdlovsk. 197 p. (In Russ.).

Shevchenko V.V., Datsky A.V. 2014. Bioeconomics of the use of commercial pollock resources of the Northern Pacific. The experience of Russian and American fishermen. M.: VNIRO. 212 p. (In Russ.).

Shuntov V.P. 2001. Biology of the Far Eastern seas of Russia. Vladivostok: TINRO-center. V. 1. 580 p. (In Russ.).

Shuntov V.P. 2016. Biology of the Far Eastern seas of Russia. Vladivostok: TINRO. V. 2.604 p. (In Russ.).

Shuntov V.P., Volkov A.F., Temnykh O.S., Dulepova E.P. 1993. Walleye pollock in ecosystems of the Far Eastern seas. Vladivostok: TINRO. 426 p. (In Russ.). 
Shuntov V.P., Ivanov O.A. 2019. Climatic changes and the current state of the biota of the Russian waters of the Far Eastern seas // Izvestia TINRO. V. 197. P. 83-107. (In Russ.).

Shuntov V.P., Ivanov O.A. 2021. "Wrong fish» or incorrect hypotheses: what happens to the nekton of the Kuril ocean waters? // Izvestia TINRO. V. 201, Is. 1. P. 3-23. (In Russ.).

Shuntov V.P., Temnykh O.S. 2008. Pacific salmon in marine and oceanic ecosystems. Vladivostok: TINRO-Center. V. 1. 481 p. (In Russ.).

Shuntov V.P., Temnykh O.S. 2011. Pacific salmon in marine and oceanic ecosystems. Vladivostok: TINRO-Center. V. 2. 473 p. (In Russ.).

Yazev S.A., Levi K.G., Zadonina N.V. 2009. Global warming and questions of scientific methodology // Izvestiya Irkutsk unta. Series “Earth Sciences”. V. 1, № 1. P. 198-213. (In Russ.).

Albanese D., Filosi M., Visintainer R., Riccadonna S., Jurman G., Furlanello C. 2012. Minerva and minepy: a C engine for the MINE suite and its R, Python and MATLAB wrappers // Bioin-formatics. V. 29, Is. 3. P. 406-407.

Datsky A.V., Kulik V.V., Datskaya S.A. 2021. Maximal information coefficients between some abiotic factors and fish stocks in the north-west Pacific, Mendeley Data, v4, doi: 10.17632/ d5hy9smz5p.4. Accessible via: https://data.mendeley.com/ datasets/d5hy9smz5p/4.

Hastie T., Tibshirani R. 1990. Generalized Additive Models. London: Chapman \& Hall. 467 p.

Hinckley S. 1987. The reproductive biology of walleye pollock, Theragra chalcogramma, in the Bering Sea, with reference to spawning stock structure // Fish. Bull. V. 85, № 3. P. 481498.

Ianelli J.N., Honkalehto T., Barbeaux S., Kotwicki S., Aydin K., Williamson N. 2013. Assessment of the walleye pollock stock in the Eastern Bering Sea. Accessible via: http://www. afsc.noaa.gov/REFM/docs/2013/EBSpollock.pdf.

Ianelli J.N., Kotwicki S., Honkalehto T., McCarthy A., Stienessen S., Holsman K. 2018. Chapter 1: Assessment of the walleye pollock stock in the Easter Bering Sea. Accessible via: https://www.afsc.noaa.gov/REFM/docs/2018/ BSAl/2018EBSpollock.pdf.

Kinney J.B., Atwal G.S. 2014. Equitability, mutual information, andthe maximal information coefficient // Proc. Natl. Acad. Sci. USA. 111(9). P. 3354-3359.

Large S.I, Fay G., Friedland K.D., Link J.S. 2015. Critical points in ecosystem responses to fishing and environmental pressures // Mar. Ecol. Prog. Ser. V. 521. P. 1-17.

McArthur R.H., Wilson E.O. 1967. The theory of island biogeography // Princeton (N.J.): Princeton Univ. Press. $203 \mathrm{p}$.

NPAFC. Rezhim dostupa: http://www.npafc.org/new/science_ statistics.html. 09.09.2021.

Okada K. 1986. Biological characteristics and abundance of pelagic pollock in the Aleutian Basin // Bull. INPFC. № 45. P. 150-176.
Ormseth O.A. 2019. Status of forage species in the Bering Sea and Aleutian Islands region. Alaska Fisheries Science Center. P. 1-46. Accessible via: https://apps-afsc.fisheries.noaa.gov/ $\mathrm{refm} / \mathrm{docs} / 2019 / \mathrm{BSAlforage.pdf}$.

Reshef D.N. Reshef Y.A., Mitzenmacher M., Sabeti P.C. 2014. Cleaning up the record on the max-imal information coefficient and equitability // Proc. Natl. Acad. Sci. V. 111, № 33. P. 3362-3363.

Reshef D.N., Reshef Y.A., Finucane H.K., Grossman S.R., McVean G., Turnbaugh P.J., Lander E.S., Mitzenmacher M., Sabeti P.C. 2011. Detecting novel associations in large data sets // Science. V. 334, № 6062. P. 1518-1524.

Sakamoto Y., Ishiguro M., Kitagawa G. 1986. Akaike Information Criterion Statistics. D. Reidel Publishing Company. Tokyo, Dordrecht etc. 290 p.

Siddon E., Zador S. 2017. Status of theEastern Bering Sea Marine Ecosystem. Ecosystem Consid-erations 2017. North Pacific Fishery Management Council. Anchorage, AK. P. 1-229. Accessible via: https://www.afsc.noaa.gov/REFM/ Docs/2017/ecosysEBS.pdf.

Stepanenko M.A. 1989. The state of stocks and distribution of pollock in the Bering Sea // Proc. Intern. Symp. Biol. Managem. Walleye Pollock, Nov. 1988. Fairbanks, Alaska. P. 537-547.

Vasilets P.M. 2015. FMS analyst - computer program for processing data from Russian Fishery Monitoring System. doi:10.13140/RG.2.1.5186.0962.

Vinnikov A.V. 1996. Pacific cod (Gadus macrocephalus) of the Western Bering Sea // Ecology of Bering Sea: a review of Russian literature (Mathisen O.A., Coyle K.O., eds.). Alaska Sea Grant Report № 96-01. Fairbanks: University of Alaska. P. 183-202.

Wood S.N. 2003. Thin plate regression splines // J.R. Stat. Soc. Ser. B (Statistical Methodol). V. 65, № 1. P. 95-114.

Wood S.N. 2011. Fast stable restricted maximum likelihood and marginal likelihood estimation of semiparametric generalized linear models // J.R. Stat. Soc. Ser. B (Statistical Methodol). V. 73, № 1. P. 3-36.

Wood S.N., Shaw S., Goude Y. 2015. Generalized additive models for large data sets // J.R. Stat. Soc. Ser. C (Applied Stat.). V. 64, № 1. P. 139-155.

Поступила в редакцию 17.01.2020 г. Принята после рецензии 03.09.2021 2. 